\title{
Protocol
}

\section{In Vitro Reconstitution of Yeast Translation System Capable of Synthesizing Long Polypeptide and Recapitulating Programmed Ribosome Stalling}

\author{
Riku Nagai, Yichen Xu, Chang Liu, Ayaka Shimabukuro and Nono Takeuchi-Tomita * \\ Department of Computational Biology and Medical Sciences, Graduate School of Frontier Sciences, \\ The University of Tokyo, 5-1-5, Kashiwanoha, Kashiwa-shi, Chiba 277-8562, Japan; \\ nagai-r1@g.ecc.u-tokyo.ac.jp (R.N.); 2966215542@edu.k.u-tokyo.ac.jp (Y.X.); \\ 4793414629@edu.k.u-tokyo.ac.jp (C.L.); 8938900508@edu.k.u-tokyo.ac.jp (A.S.) \\ * Correspondence: nono@edu.k.u-tokyo.ac.jp; Tel.: +81-04-7136-3641
}

check for updates

Citation: Nagai, R.; Xu, Y.; Liu, C.; Shimabukuro, A.; Takeuchi-Tomita, N. In Vitro Reconstitution of Yeast Translation System Capable of Synthesizing Long Polypeptide and Recapitulating Programmed Ribosome Stalling. Methods Protoc. 2021, 4, 45. https://doi.org/10.3390/ mps4030045

Academic Editor: Fernando Albericio

Received: 31 May 2021

Accepted: 24 June 2021

Published: 4 July 2021

Publisher's Note: MDPI stays neutral with regard to jurisdictional claims in published maps and institutional affiliations.

Copyright: (c) 2021 by the authors. Licensee MDPI, Basel, Switzerland. This article is an open access article distributed under the terms and conditions of the Creative Commons Attribution (CC BY) license (https:// creativecommons.org/licenses/by/ $4.0 /)$.

\begin{abstract}
The rates of translation elongation or termination in eukaryotes are modulated through cooperative molecular interactions involving mRNA, the ribosome, aminoacyl- and nascent polypeptidyltRNAs, and translation factors. To investigate the molecular mechanisms underlying these processes, we developed an in vitro translation system from yeast, reconstituted with purified translation elongation and termination factors, utilizing CrPV IGR IRES-containing mRNA, which functions in the absence of initiation factors. The system is capable of synthesizing not only short oligopeptides but also long reporter proteins such as nanoluciferase. By setting appropriate translation reaction conditions, such as the $\mathrm{Mg}^{2+}$ / polyamine concentration, the arrest of translation elongation by known ribosome-stalling sequences (e.g., polyproline and CGA codon repeats) is properly recapitulated in this system. We describe protocols for the preparation of the system components, manipulation of the system, and detection of the translation products. We also mention critical parameters for setting up the translation reaction conditions. This reconstituted translation system not only facilitates biochemical analyses of translation but is also useful for various applications, such as structural and functional studies with the aim of designing drugs that act on eukaryotic ribosomes, and the development of systems for producing novel functional proteins by incorporating unnatural amino acids by eukaryotic ribosomes.
\end{abstract}

Keywords: CrPV IGR IRES; in vitro translation; translation elongation; translation termination; yeast

\section{Introduction}

The reconstitution of biological processes is critical for the investigation of the underlying molecular mechanisms. Regarding the translation of mRNA, some reconstituted translation systems have, so far, been developed with bacterial (Escherichia coli [1], Thermus thermophilus [2], Mycobacterium [3]), human [4], and mammalian mitochondrial factors [5]. A system from yeast Saccharomyces cerevisiae has been long-awaited, as yeast is one of the best-characterized model eukaryotes with a variety of resources. For yeast, the individual steps of translation have been partially reconstituted: initiation [6,7], peptide elongation [8-11], and termination and ribosome recycling [11-14]. Combination of these in vitro systems allowed synthesizing oligopeptides, and the direct measurement of the kinetics of translation elongation, by manipulating mRNA coding sequence, tRNA identity and concentration, as well as ribosome and translation factor composition [15]. However, until recently, the translation of a long peptide has not been attempted. This is partly because cap-dependent translation initiation and tRNA aminoacylation are complicated biological processes. Cap-dependent initiation is the most complex stage of translation in yeast, requiring at least 12 initiation factors, with many being composed of several peptides [6]. Moreover, the tRNA aminoacylation process is also highly complex, as 20 
different aminoacyl-tRNA synthetases and their cofactors are involved in charging tRNAs with their cognate amino acids $[16,17]$.

We have recently developed an in vitro reconstituted translation system that is capable of synthesizing long peptides [18]. In this system, in order to bypass the complex initiation process, we exploited CrPV IGR IRES (intergenic region internal ribosome entry site sequence from cricket paralysis virus)-containing mRNA, whereby yeast $80 \mathrm{~S}$ ribosomes initiate in the absence of initiator tRNA or any eukaryotic translation initiation factors [19,20]. The translation elongation process was reconstituted by using yeast elongation factors (eEF1A, eEF2, and the fungal-specific elongation factor eEF3 [15,21-23]) and pre-charged aminoacyl-tRNAs. To prepare aminoacyl-tRNAs, a yeast tRNA mixture was charged by yeast $\mathrm{S} 100$ extract, which we found to be capable of template-dependent synthesis of long polypeptides. Termination factors (eRF1 and eRF3) and recycling factors (Rli1, Hbs1, and Dom34) were further combined, in order to complete the reconstituted in vitro translation system. By setting appropriate translation reaction conditions, such as the $\mathrm{Mg}^{2+}$ / polyamine concentration, the arrest of translation elongation by known ribosome-stalling sequences (e.g., polyproline and CGA codon repeats) can be properly recapitulated in this system. This system made it possible to analyze the translation elongation and termination, with greater control over the length and sequence of mRNA and nascent peptides. For example, by utilizing this system, we have examined the role of the eukaryotic translation factor eIF5A and its hypusine modification in translating the polyproline sequence within long open reading frames. We demonstrated that the requirement of the hypusine modification of eIF5A to alleviate the polyproline-mediated ribosome-stalling depends on the location and length of the polyproline motif in the protein [24].

Here, we describe detailed protocols for the preparation of the system components, manipulation of the system, and detection of the translation products. We also mention the translation reaction conditions, in order to recapitulate the programmed ribosome stalling. This reconstituted yeast translation system facilitates biochemical analyses of translation elongation, termination, and ribosome recycling on natural mRNAs, and also provides a framework for studying co-translational events, such as protein folding, targeting, and degradation through the ribosome-associated quality control (RQC) pathway. Moreover, the system is potentially useful for various applications; for example, it is suitable for use in structural and functional studies to design drugs that act on eukaryotic ribosomes, such as antibiotics against fungi. As the system allows for research into the effect of mRNA- or nascent peptide-context on translation termination, it could also be applied for the development of readthrough-inducing agents for treating genetic diseases caused by nonsense mutations. Other applications of this system include the template-dependent synthesis of proteins containing unnatural amino acids by eukaryotic ribosomes, using synthetic tRNAs that have been appropriately charged for example, with ribozymes. In combination with ribosome- or mRNA-display systems, this system could serve as a powerful in vitro screening system for novel functional proteins, such as antimicrobial peptides with cytotoxicity.

\section{Experimental Design}

This protocol describes the reconstitution of the yeast translation system in vitro, which is capable of synthesizing long polypeptides following CrPV-IRES-mediated translation initiation, as well as recapitulating the translation elongation arrest by known downregulating sequences, such as the polyproline sequence. As illustrated in Figure 1, the procedure includes five parts: (i) preparation of yeast translation factors (elongation factors, termination factors, recycling factors, ribosomes, tRNAs); (ii) preparation of aminoacyl-tRNAs by charging yeast crude tRNA mixtures using yeast S100 extract; (iii) preparation of CrPV IRES-containing mRNA by in vitro transcription using T7 RNA polymerase; (iv) the translation reaction; and (v) analysis of the translation products. In the following, we explain the parameters that critically determine the properties of the reconstituted translation system. 


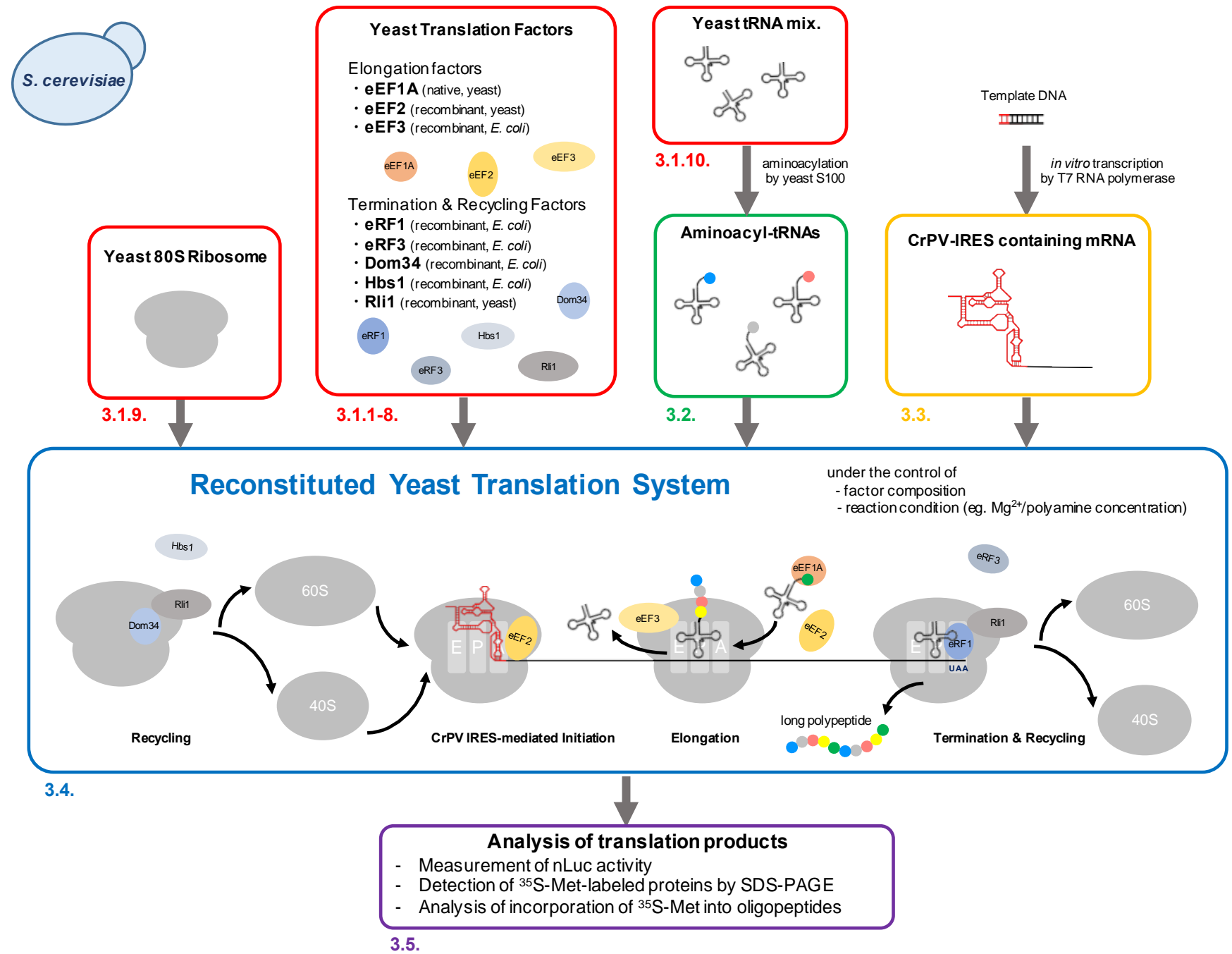

Figure 1. Schematic overview of reconstitution of yeast translation system capable of synthesizing long polypeptides and recapitulating the programmed ribosome stalling. Each procedure is described in the section shown below the rectangle. See the "Experimental Design" section for details.

\section{eEF1A concentration}

A high eEF1A concentration-that is, 10 - to 20 -fold relative to the ribosome concentration - is required for efficient translation reactions, especially to synthesize long polypeptides. For example, the synthesis yield of the reporter protein nanoluciferase (nLuc) using an equivalent amount of eEF1A to ribosomes drops three orders of magnitude from that when using 10-fold eEF1A; that is, the yield of nLuc drops from $0.03 \mathrm{nM}$ to $0.03 \mathrm{pM}$ [18]. We found that such a high eEF1A concentration is important to ensure the dominance of IRES-mediated translation initiation over IRES-independent random internal translation initiation [18]. In the CrPV IRES-mediated translation initiation, the delivery of the first tRNA by eEF1A governs the overall efficiency of initiation $[19,25]$. Thus, for the long mRNA encoding long polypeptides, ternary complexes (eEF1A •aa-tRNA $\bullet$ GTP) may possibly be consumed by the IRES-independent random internal translation initiation, thereby inhibiting the IRES-dependent translation initiation. Indeed, a high eEF1A concentration is not strictly required when the short mRNA encoding an oligopeptide is translated with the system. The synthesis of oligopeptides using an equivalent amount of eEF1A to ribosomes is reduced to, at most, one-fifth of that using 10-fold eEF1A (i.e., the yield of oligopeptide synthesis drops from $3 \mathrm{nM}$ to $0.6 \mathrm{nM}$ [18]), whereby the required eEF1A amount is roughly proportional to the number of amino acids to be polymerized.

Magnesium/polyamine concentration 
It is important to set an appropriate $\mathrm{Mg}^{2+}$ and polyamine concentrations in the reconstituted yeast translation system, in order to recapitulate polyproline-mediated ribosome stalling. We have previously demonstrated that polyproline arrests translation in a manner similar to 'intrinsic ribosome destabilization (IRD)' [24]. IRD is a recently discovered phenomenon in bacteria, where consecutive and proline-intermitted acidic amino acids destabilize the 705 ribosome from within the peptide tunnel and abort translation [26]. Thus, in a yeast reconstituted translation system, under conditions with relatively lower $\mathrm{Mg}^{2+}$, polyproline destabilizes both the peptidylpolyproline-tRNA itself and the ribosome, inhibiting the peptidyl transfer reaction. However, under conditions with relatively higher $\mathrm{Mg}^{2+}$ (where ribosomes are stable), the disorder of the peptidylpolyproline-tRNA is resolved, consequently alleviating polyproline-mediated ribosome stalling. To analyze polyproline-mediated ribosome stalling or other potential magnesium/polyaminedependent translation regulation, we usually set the concentration of $\mathrm{Mg}^{2+}$ in a range of about 5 to $7 \mathrm{mM}$, in the presence of $0.25 \mathrm{mM}$ spermidine. The precise $\mathrm{Mg}^{2+}$ concentration needs to be determined, depending on the lot of $80 \mathrm{~S}$ ribosome preparation, as described later (see Figure 2). Ribosome stalling is alleviated and no longer observed at $\mathrm{Mg}^{2+}$ concentrations above a specific concentration between 5 and $7 \mathrm{mM}$.

We commonly use mRNA and pre-charged aa-tRNAs for the translation reaction in the reconstituted translation system (Figure 1). On the other hand, by including a DNA template, T7 RNA polymerase, and/or purified aminoacyl-tRNA synthetases (human aminoacyl-tRNA synthetases [4]) in the system, it is also possible to perform a translation reaction coupled with transcription and/or aminoacylation reaction, which greatly simplifies the experiments and saves time (see Section 3.4); however, care must be taken that the T7 RNA polymerase and aminoacyl-tRNA synthetases consume triphosphate nucleotides which chelate $\mathrm{Mg}^{2+}$ during the reaction, such that the control of $\mathrm{Mg}^{2+}$ concentration is difficult in such transcription- and aminoacylation-coupled systems.

We prefer polyamine-containing conditions, such as $5 \mathrm{mM} \mathrm{Mg}^{2+}, 0.25 \mathrm{mM}$ spermidine, and $0 \mathrm{mM}$ spermine (designated hereafter as [5/0.25/0]), over polyamine-free conditions, in order to maintain the translation fidelity [27].

\subsection{Reagents}

- $\quad$ HEPES (Dojindo, Tokyo, Japan, Cat. no.: 342-01375)

- $\quad$ Potassium hydroxide (KOH) (Wako, Tokyo, Japan, Cat. no.: 168-21815)

- Tris(hydroxymethyl)aminomethane (Tris) (Wako, Cat. no.: 207-06275)

- Hydrochloric acid (HCl) (Wako, Cat. no.: 080-01066)

- $\quad$ Acetic acid (Wako, Cat. no.: 017-00251)

- $\quad$ Boric acid (Wako, Cat. no.: 021-02195)

- $\quad$ EDTA•2Na (EDTA) (Dojindo, Cat. no.: 345-01865)

- $\quad$ Potassium chloride (KCl) (Wako, Cat. no.: 163-03545)

- $\quad$ Ammonium acetate (Wako, Cat. no.: 019-02835)

- $\quad$ Ammonium chloride $\left(\mathrm{NH}_{4} \mathrm{Cl}\right)$ (Wako, Cat. no.: 017-02995)

- Magnesium chloride hexahydrate $\left(\mathrm{MgCl}_{2}\right)$ (Wako, Cat. no.: 135-00165)

- Magnesium acetate tetrahydrate $\left(\mathrm{Mg}(\mathrm{OAc})_{2}\right)$ (Wako, Cat. no.: 130-00095)

- $\quad$ MOPS (Dojindo, Cat. no.: 343-01805)

- Imidazole (Wako, Cat. no.: 095-00015)

- Ammonium sulfate $\left(\left(\mathrm{NH}_{4}\right)_{2} \mathrm{SO}_{4}\right)$ (Wako, Cat. no.: 013-03433)

- $\quad$ Sucrose (Wako, Cat. no.: 196-00015)

- $\quad$ Dithiothreitol (DTT) (Wako, Cat. no.: 049-08972)

- 2-Mercaptoethanol ( $\beta-M e)$ (Wako, Cat. no.: 131-14572)

- $\quad$ Phenylmethanesulfonyl fluoride (PMSF) (Sigma-Aldrich, St. Louis, MO, USA, Cat. no.: P7626)

- Isopropyl- $\beta$-D-thiogalactopyranoside (IPTG) (Nacalai tesque, Tokyo, Japan, Cat. no.: 19742-94)

- $\quad$ Sodium chloride $(\mathrm{NaCl})$ (Wako, Cat. no.: 191-01665) 
- $\quad$ Bacto tryptone (Thermo Fisher Scientific, Waltham, MA, USA, Cat. no.: 211705)

- Bacto yeast extract (Thermo Fisher Scientific, Cat. no.: 212750)

- Hipolypepton (Wako, Cat. no. 392-02115)

- $\quad \mathrm{D}(+)$-Glucose (Wako, Cat. no.: 049-31165)

- $\quad \mathrm{D}(+)$-Raffinose (Wako, Cat. no.: 184-00015)

- $\quad \mathrm{D}(+)$-Galactose (Wako, Cat. no.: 075-00035)

- Difco yeast nitrogen base w/o amino acids (Becton, Dickinson and company, Sparks, MD, USA, Cat. no.: 291940)

- $\quad$ Sodium hydroxide (NaOH) (Wako, Cat. no.: 198-13765)

- $\quad$ Sodium acetate, anhydrous (NaOAc) (Wako, Cat. no.: 192-01075)

- $\quad$ Potassium acetate (KOAc) (Wako, Cat. no.: 160-03175)

- Phenol, granular (Nacalai tesque, Cat. no.: 26728-45)

- 2-Propanol (Wako, Cat. no.: 166-04836)

- Ethanol (Wako, Cat. no.: 057-00451)

- Methanol (Wako, Cat. no.: 137-01823)

- Chloroform (Wako, Cat. no.: 038-02601)

- Isoamyl alcohol (Tokyo chemical industry, Tokyo, Japan, Cat. no.: I0289)

- ISOGEN-LS (Nippon gene, Tokyo, Japan, Cat. no.: 311-02621)

- Formaldehyde solution (Formalin) (Nacalai tesque, Cat. no.: 16223-55)

- $\quad$ Formamide (Nacalai tesque, Cat. no.: 16345-65)

- Complete mini protease inhibitor cocktail tablets, EDTA-free (Sigma-Aldrich, St. Louis, MO, USA, Cat. no.: 11836170001)

- $\quad 30 w / v \%$ acrylamide/Bis mixed solution (37.5:1) (Wako, Cat. no.: 018-25625)

- Sodium dodecyl sulfate (SDS) (Wako, Cat. no.: 191-07145)

- Ammonium peroxodisulfate (APS) (Wako, Cat. no.: 012-03285)

- $\quad N, N, N^{\prime}, N^{\prime}$-tetramethyl-ethylenediamine (TEMED) (Wako, Cat. no.: 205-06313)

- Urea (Wako, Cat. no.: 215-00616)

- $\quad$ CBB R-250 (CBB) (Wako, Cat. no.: 031-17922)

- Xylene cyanole FF (XC) (Sigma-Aldrich, Cat. no.: X4126)

- $\quad$ Bromophenol blue (BPB) (Wako, Cat. no.: 021-02911)

- $\quad$ Lithium dodecyl sulfate (LiDS) (Sigma-Aldrich, Cat. no.: L4632)

- $\quad$ Acrylamide (Wako, Cat. no.: 011-08015)

- $\quad$ N,N'-methylene-bis(acrylamide)-HG (BIS) (Wako, Cat. no.: 138-08173)

- Bio-Rad Protein Assay Dye Reagent Concentrate (Bio-Rad, Hercules, CA, USA, Cat. no.: 5000006)

- Ethidium bromide solution $10 \mathrm{mg} / \mathrm{mL}$ (EtBr) (Nacalai tesque, Cat. no.: 14631-94)

- $\quad$ ATP lithium salt (ATP) (Roche, Cat. no.: 11140965001)

- $\quad$ CTP lithium salt (CTP) (Roche, Cat. no.: 11140922001)

- $\quad$ GTP lithium salt (GTP) (Roche, Cat. no.: 11140957001)

- UTP lithium salt (UTP) (Roche, Cat. no.: 11140949001)

- $\quad$ Creatine phosphate (CP) (Roche, Cat. no.: 10621722001)

- $\quad$ Spermidine (SPD) (Wako, Cat. no.: 197-13833)

- $\quad$ Spermine (SP) (Wako, Cat. no.: 194-09813)

- L-Glutamic acid potassium salt monohydrate (Sigma-Aldrich, Cat. no.: G1501)

- $\quad$ Adenine hydrochloride (Adenine) (Wako, Cat. no.: 016-00802)

- myo-Inositol (L-Inositol) (Wako, Cat. no.: 092-00282)

- p-Aminobenzoic acid (Wako, Cat. no.: 015-02332)

- L-Alanine (Ala) (Wako, Cat. no.: 010-01042)

- $\quad$ L-Arginine (Arg) (Sigma-Aldrich, Cat. no.: A8094)

- L-Asparagine monohydrate (Asn) (Wako, Cat. no.: 019-04812)

- L-Aspartic acid (Asp) (Wako, Cat. no.: 013-04832)

- L(+)-Glutamine (Gln) (Wako, Cat. no.: 074-00522)

- $\quad$ L-Glutamic acid (Glu) (Wako, Cat. no.: 070-00502)

- $\quad$ Glycine (Gly) (Wako, Cat. no.: 073-00732) 
- $\quad$ L-Histidine (His) (Sigma-Aldrich, Cat. no.: H6034)

- $\quad \mathrm{L}(+)-$-Isoleucine (Ile) (Wako, Cat. no.: 123-00861)

- $\quad$ L-Leucine (Leu) (Wako, Cat. no.: 126-00851)

- $\quad$ L-Lysine (Lys) (Sigma-Aldrich, Cat. no.: L5501)

- L(-)-Phenylalanine (Phe) (Wako, Cat. no.: 163-01301)

- L(-)-Proline (Pro) (Wako, Cat. no.: 163-04601)

- $\quad$ L-Serine (Ser) (Wako, Cat. no.: 191-00401)

- L(-)-Threonine (Thr) (Wako, Cat. no.: 206-01321)

- L-Tryptophan (Trp) (Wako, Cat. no.: 206-03381)

- $\quad$ L-Tyrosine (Tyr) (Wako, Cat. no.: 204-03561)

- L-Valine (Val) (Wako, Cat. no.: 220-00081)

- L-Cysteine (Cys) (Sigma-Aldrich, Cat. no.: C7352)

- $\quad$ L-Methionine (Met) (Wako, Cat. no.: 133-01602)

- Methionine, L-[ ${ }^{35}$ S]-(Met) (Perkin Elmer, Waltham, MA, USA, Cat. no.: NEG009A)

- Guanidine thiocyanate (Nacalai tesque, Cat. no.: 17345-35)

- $\quad$ Trisodium citrate dihydrate (Wako, Cat. no.: 191-01785)

- N-Lauroylsarcosine sodium salt (Sarcosyl) (Nacalai tesque, Cat. no.: 20117-12)

- Y-PER Yeast Protein Extraction Reagent (Thermo Fisher Scientific, Cat. no.: 78990)

- $\quad$ TWEEN 20 Detergent (Merck, Darmstadt, Germany, Cat. no.: 655205)

- Heparin sodium (Wako, Cat. no.: 081-00136)

- Puromycin dihydrochloride (puromycin•2HCl) (Wako, Cat. no.: 166-23153)

- $\quad$ Glycerol (Wako, Cat. no.: 075-00611)

- KOD-Plus-Neo (Toyobo, Tokyo, Japan, Cat. no.: KOD-401)

- $\quad D p n$ I (Takara, Tokyo, Japan, Cat. no.: 1235A)

- $10 \times$ loading buffer (Takara, Cat. no.: 9157)

- $\quad$ Agarose L03 TAKARA (Takara, Cat. no.: 5003)

- Recombinant RNase Inhibitor (Takara, Cat. no.: 2313A)

- $\quad$ TURBO DNase (Thermo Fisher Scientific, Cat. no.: AM2238)

- RNase A (Macherey-Nagel, Düren, Germany, Cat. no.: 740505.05)

- $\quad$ RNase-free water (generated by an ultrapure water system)

\subsection{Equipment}

- $\quad$ AKTA explorer (Cytiva, Tokyo, Japan)

- Ultracentrifuge (Beckman coulter, Fullerton, CA, USA, Cat. no.: Optima LE-80K)

- Type 45 Ti Rotor (Beckman coulter, Cat. no.: 339160)

- $\quad$ Type 70 Ti Rotor (Beckman coulter, Cat. no.: 337922)

- Ultracentrifuge tube for $45 \mathrm{Ti}, 70 \mathrm{~mL}$ (Beckman coulter, Cat. no.: 355622)

- $\quad$ Ultracentrifuge tube for $70 \mathrm{Ti}, 26.3 \mathrm{~mL}$ (Beckman coulter, Cat. no.: 355618)

- Mortar Mill RM200 (Retsch, Rheinische, Germany)

- Digital Sonifier 450 (Branson, Danbury, CT, USA)

- $\quad$ BAS5000 (Fujifilm, Tokyo, Japan)

- Scintillation counter, LSC-6100 (ALOKA, Tokyo, Japan)

- Wizard SV Gel and PCR Clean-Up System (Promega, Madison, WI, USA, Cat. no.: A9281)

- Micro Bio-Spin columns P-30, Tris (Bio-Rad, Cat. no.: 732-6250)

- NAP-5 columns (Cytiva, Cat. no: 17-0853-01)

- Amicon ultra centrifugal filters (Merck Millipore, Burlington, MA, USA, Cat. no.: UFC9010) 
A

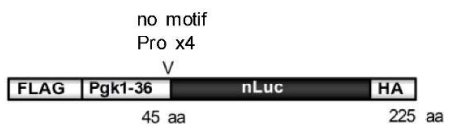

B

$5 \mathrm{mM} \mathrm{Mg}^{2+}$

1

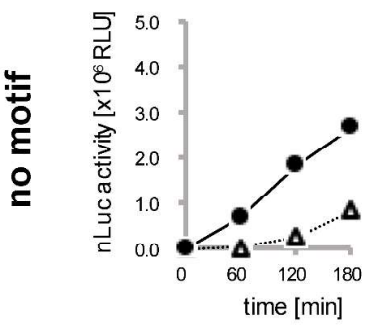

4

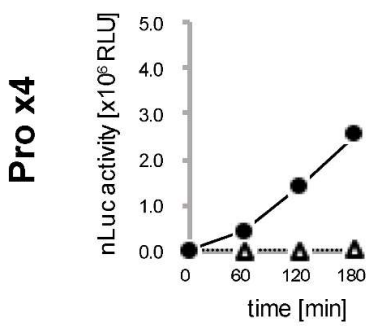

C

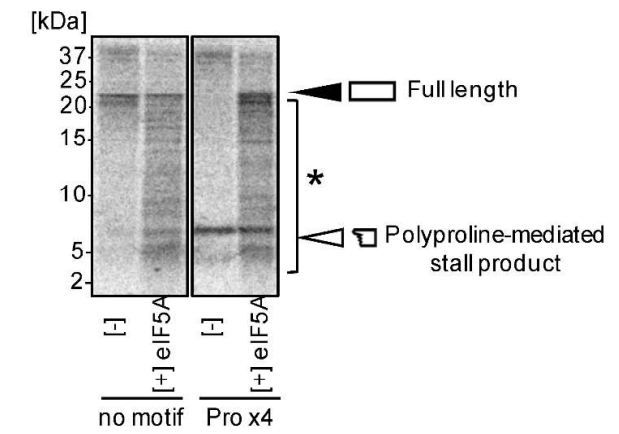

2

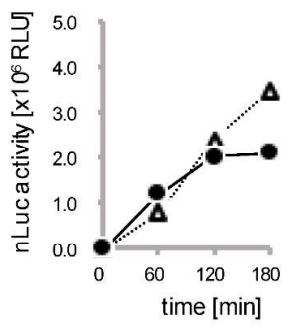

5

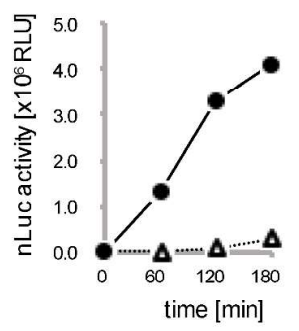

time [min]
$7 \mathrm{mM} \mathrm{Mg}{ }^{2+}$

3

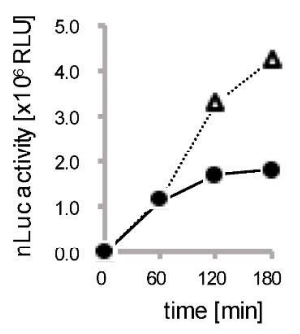

6

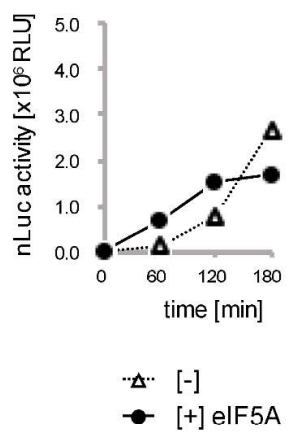

Figure 2. Analysis of translational ability of purified $80 \mathrm{~S}$ ribosomes and determination of the appropriate $\mathrm{Mg}^{2+}$ concentration to recapitulate the polyproline-mediated ribosomal stalling. After the purification of ribosomes, their translational abilities are checked using the indicated mRNAs (see also Table S4). Shown are the examples: (A) schematic of the mRNAs; (B) translation reactions were performed using mRNA and $\left.{ }^{35} \mathrm{~S}\right]$ methionine-labelled aminoacyl-tRNA mix, with 5-7 mM $\mathrm{Mg}^{2+}, 0.25 \mathrm{mM}$ spermidine, and $0 \mathrm{mM}$ spermine. Where indicated, $0.5 \mu \mathrm{M}$ hypusinated eIF5A protein - equivalent to the amount of ribosomes-was included in the reaction. After incubation for the indicated time period, aliquots were subjected to nLuc assay. [-] (open triangle), no protein; [+] eIF5A (closed circle), eIF5A(hyp). (C) After 180-min reaction, the translation products at $6 \mathrm{mM}$ $\mathrm{Mg}^{2+}$ (Panels 2 and 5 in (B)) were analyzed by Tricine SDS-PAGE. Black triangle, full-length product; open triangle, polyproline-mediated stall product. Asterisk indicates unknown products that are specifically produced in the presence of eIF5A, and may possibly be premature termination products (see text and [24]). For the preparation of eIF5A, see Appendix C. 


\subsection{Reagents Setup}

Reagents, except for heat-sensitive liquids, should be sterilized by a combination of filtration and autoclaving.

Reagents, as well as equipment such as pipette tips and glassware, for the RNA preparation should be RNase-free.

Solutions for column chromatography are filter-sterilized. $\beta$-Me, DTT, PMSF, protease inhibitor cocktail, and others when indicated, are added to buffers immediately before use.

\subsection{1. eEF1A Preparation}

Lysis buffer: $60 \mathrm{mM}$ Tris- $\mathrm{HCl}$ (pH 7.5), $50 \mathrm{mM} \mathrm{KCl}, 5 \mathrm{mM} \mathrm{MgCl} 2,0.1 \mathrm{mM}$ EDTA, 10\% (vol/vol) glycerol, $20 \mu \mathrm{M}$ GDP, $0.2 \mathrm{mM}$ PMSF, and $2 \mathrm{mM}$ DTT. Mix $60 \mathrm{~mL}$ of $1 \mathrm{M}$ Tris-HCl ( $\mathrm{pH} 7.5$ ), $3.73 \mathrm{~g}$ of $\mathrm{KCl}, 5 \mathrm{~mL}$ of $1 \mathrm{M} \mathrm{MgCl}_{2}, 200 \mu \mathrm{L}$ of $0.5 \mathrm{M}$ EDTA (pH 8.0), $100 \mathrm{~mL}$ of glycerol, $100 \mu \mathrm{L}$ of $200 \mathrm{mM}$ GDP, $2 \mathrm{~mL}$ of $100 \mathrm{mM}$ PMSF, and $2 \mathrm{~mL}$ of $1 \mathrm{M}$ DTT, and then add RNase-free water up to $1 \mathrm{~L}$. Add 1 tablet of complete mini protease inhibitor cocktail (Roche) per $10 \mathrm{~mL}$ of buffer. Add GDP immediately before use.

HiTrap SP A buffer: $20 \mathrm{mM}$ Tris- $\mathrm{HCl}$ (pH 7.5), $5 \mathrm{mM} \mathrm{MgCl} 2,25 \%$ (vol/vol) glycerol, $10 \mu \mathrm{M}$ GDP, $0.1 \mathrm{mM}$ PMSF, and $2 \mathrm{mM}$ DTT. Mix $20 \mathrm{~mL}$ of $1 \mathrm{M}$ Tris- $\mathrm{HCl}(\mathrm{pH} 7.5), 5 \mathrm{~mL}$ of $1 \mathrm{M}$ $\mathrm{MgCl}_{2}, 250 \mathrm{~mL}$ of glycerol, $50 \mu \mathrm{L}$ of $200 \mathrm{mM} \mathrm{GDP}, 1 \mathrm{~mL}$ of $100 \mathrm{mM} \mathrm{PMSF}$, and $2 \mathrm{~mL}$ of $1 \mathrm{M}$ DTT, and then, add RNase-free water up to $1 \mathrm{~L}$. Add GDP immediately before use.

HiTrap SP B buffer: $20 \mathrm{mM}$ Tris- $\mathrm{HCl}$ (pH 7.5), $1 \mathrm{M} \mathrm{KCl}, 5 \mathrm{mM} \mathrm{MgCl} 2,25 \%$ (vol/vol) glycerol, $10 \mu \mathrm{M}$ GDP, $0.1 \mathrm{mM}$ PMSF, and $2 \mathrm{mM}$ DTT. Mix $20 \mathrm{~mL}$ of $1 \mathrm{M}$ Tris-HCl (pH 7.5), $74.6 \mathrm{~g}$ of KCl, $5 \mathrm{~mL}$ of $1 \mathrm{M} \mathrm{MgCl}_{2}, 250 \mathrm{~mL}$ of glycerol, $50 \mu \mathrm{L}$ of $200 \mathrm{mM}$ GDP, $1 \mathrm{~mL}$ of $100 \mathrm{mM}$ PMSF, and $2 \mathrm{~mL}$ of $1 \mathrm{M}$ DTT, and then, add RNase-free water up to $1 \mathrm{~L}$. Add GDP immediately before use.

HiTrap Butyl A buffer: $20 \mathrm{mM}$ HEPES-KOH (pH 7.5), $1.4 \mathrm{M}\left(\mathrm{NH}_{4}\right)_{2} \mathrm{SO}_{4}, 5 \mathrm{mM} \mathrm{MgCl}_{2}, 10 \%$ (vol/vol) glycerol, $10 \mu \mathrm{M}$ GDP, and $2 \mathrm{mM}$ DTT. Mix $20 \mathrm{~mL}$ of $1 \mathrm{M}$ HEPES-KOH (pH 7.5), $185 \mathrm{~g}$ of $\left(\mathrm{NH}_{4}\right)_{2} \mathrm{SO}_{4}, 5 \mathrm{~mL}$ of $1 \mathrm{M} \mathrm{MgCl}_{2}, 100 \mathrm{~mL}$ of glycerol, $50 \mu \mathrm{L}$ of $200 \mathrm{mM} \mathrm{GDP}$, and $2 \mathrm{~mL}$ of $1 \mathrm{M}$ DTT, and then, add RNase-free water up to $1 \mathrm{~L}$. Add GDP immediately before use.

HiTrap Butyl B buffer: $20 \mathrm{mM}$ HEPES-KOH (pH 7.5), $5 \mathrm{mM} \mathrm{MgCl}_{2}, 10 \%$ (vol/vol) glycerol, $10 \mu \mathrm{M}$ GDP, and $2 \mathrm{mM}$ DTT. Mix $20 \mathrm{~mL}$ of 1 M HEPES-KOH (pH 7.5), $5 \mathrm{~mL}$ of $1 \mathrm{M} \mathrm{MgCl}_{2}$, $100 \mathrm{~mL}$ of glycerol, $50 \mu \mathrm{L}$ of $200 \mathrm{mM} \mathrm{GDP}$, and $2 \mathrm{~mL}$ of $1 \mathrm{M}$ DTT, and then, add RNase-free water up to $1 \mathrm{~L}$. Add GDP immediately before use.

Stock buffer: $20 \mathrm{mM}$ HEPES-KOH (pH 7.5), $100 \mathrm{mM} \mathrm{KCl}, 5 \mathrm{mM} \mathrm{MgCl} 2,25 \%$ (vol/vol) glycerol, $10 \mu \mathrm{M}$ GDP, $0.1 \mathrm{mM}$ PMSF, and $2 \mathrm{mM}$ DTT. Mix $20 \mathrm{~mL}$ of $1 \mathrm{M}$ HEPES-KOH (pH 7.5), $7.46 \mathrm{~g}$ of KCl, $5 \mathrm{~mL}$ of $1 \mathrm{M} \mathrm{MgCl}_{2}, 250 \mathrm{~mL}$ of glycerol, $50 \mu \mathrm{L}$ of $200 \mathrm{mM} \mathrm{GDP}, 1 \mathrm{~mL}$ of $100 \mathrm{mM}$ PMSF, and $2 \mathrm{~mL}$ of $1 \mathrm{M} \mathrm{DTT}$, and then add RNase-free water up to $1 \mathrm{~L}$. Add GDP immediately before use.

\subsection{2. eEF2 Preparation}

Lysis buffer: $10 \mu \mathrm{M}$ GDP, $0.2 \mathrm{mM}$ PMSF, and $5 \mathrm{mM}$ DTT in Y-PER Yeast Protein Extraction Reagent (Thermo Fisher Scientific). Mix 7.5 $\mu \mathrm{L}$ of 200 mM GDP, $300 \mu \mathrm{L}$ of $100 \mathrm{mM}$ PMSF, and $750 \mu \mathrm{L}$ of $1 \mathrm{M}$ DTT, and then, add Y-PER up to $150 \mathrm{~mL}$. Add 1 tablet of complete mini protease inhibitor cocktail (Roche) per $10 \mathrm{~mL}$ of buffer.

Ni-NTA wash Buffer I: $50 \mathrm{mM}$ HEPES-KOH (pH 7.5), $150 \mathrm{mM} \mathrm{KCl,} 20 \mathrm{mM}$ Imidazole, $10 \%$ (vol/vol) glycerol, $10 \mu \mathrm{M}$ GDP, $0.2 \mathrm{mM}$ PMSF, and $3.5 \mathrm{mM} \beta$-Me. Mix $7.5 \mathrm{~mL}$ of $1 \mathrm{M}$ HEPES-KOH (pH 7.5), $1.68 \mathrm{~g}$ of KCl, $1.2 \mathrm{~mL}$ of $2.5 \mathrm{M}$ Imidazole (pH 7.5), $15 \mathrm{~mL}$ of glycerol, $7.5 \mu \mathrm{L}$ of $200 \mathrm{mM}$ GDP, $300 \mu \mathrm{L}$ of $100 \mathrm{mM}$ PMSF, and $38 \mu \mathrm{L}$ of $14 \mathrm{M} \beta-\mathrm{Me}$, and then, add RNase-free water up to $150 \mathrm{~mL}$. Add GDP immediately before use.

Ni-NTA wash Buffer II: $50 \mathrm{mM}$ HEPES-KOH (pH 7.5), $500 \mathrm{mM} \mathrm{KCl,} 20 \mathrm{mM}$ Imidazole, $10 \%$ (vol/vol) glycerol, $10 \mu \mathrm{M}$ GDP, $0.2 \mathrm{mM}$ PMSF, and $3.5 \mathrm{mM} \beta-\mathrm{Me}$. Mix $2.5 \mathrm{~mL}$ of $1 \mathrm{M}$ HEPES-KOH (pH 7.5), $1.86 \mathrm{~g}$ of KCl, $400 \mu \mathrm{L}$ of $2.5 \mathrm{M}$ Imidazole (pH 7.5), $5 \mathrm{~mL}$ of glycerol, $2.5 \mu \mathrm{L}$ of $200 \mathrm{mM}$ GDP, $100 \mu \mathrm{L}$ of $100 \mathrm{mM}$ PMSF, and $12.5 \mu \mathrm{L}$ of $14 \mathrm{M} \beta-\mathrm{Me}$, and then, add RNase-free water up to $50 \mathrm{~mL}$. Add GDP immediately before use. 
Ni-NTA elution buffer: 50 mM HEPES-KOH (pH 7.5), $150 \mathrm{mM} \mathrm{KCl,} 250 \mathrm{mM}$ Imidazole, $10 \%$ (vol/vol) glycerol, $10 \mu \mathrm{M}$ GDP, $0.2 \mathrm{mM}$ PMSF, and $3.5 \mathrm{mM} \beta$-Me. Mix $500 \mu \mathrm{L}$ of $1 \mathrm{M}$ HEPES-KOH (pH 7.5), $112 \mathrm{mg}$ of KCl, $170 \mathrm{mg}$ of solid imidazole, $1 \mathrm{~mL}$ of glycerol, $0.5 \mu \mathrm{L}$ of $200 \mathrm{mM} \mathrm{GDP}, 20 \mu \mathrm{L}$ of $100 \mathrm{mM}$ PMSF, and $2.5 \mu \mathrm{L}$ of $14 \mathrm{M} \beta$-Me, and then, add RNase-free water up to $10 \mathrm{~mL}$. Add GDP immediately before use.

Dialysis buffer: $20 \mathrm{mM}$ HEPES-KOH (pH 7.5), $100 \mathrm{mM} \mathrm{KCl}, 0.1 \mathrm{mM}$ EDTA, 10\% (vol/vol) glycerol, $10 \mu \mathrm{M}$ GDP, $0.2 \mathrm{mM}$ PMSF, and $1 \mathrm{mM}$ DTT. Mix $20 \mathrm{~mL}$ of $1 \mathrm{M}$ HEPES-KOH (pH 7.5), $7.46 \mathrm{~g}$ of KCl, $200 \mu \mathrm{L}$ of $0.5 \mathrm{M}$ EDTA (pH 8.0), $100 \mathrm{~mL}$ of glycerol, $50 \mu \mathrm{L}$ of $200 \mathrm{mM}$ GDP, $2 \mathrm{~mL}$ of $100 \mathrm{mM}$ PMSF, and $1 \mathrm{~mL}$ of $1 \mathrm{M}$ DTT, and then, add RNase-free water up to $1 \mathrm{~L}$. Add GDP immediately before use.

HiTrap Q A buffer: 20 mM HEPES-KOH (pH 7.5), $0.1 \mathrm{mM}$ EDTA, 10\% (vol/vol) glycerol, $10 \mu \mathrm{M}$ GDP, and $1 \mathrm{mM}$ DTT. Mix $10 \mathrm{~mL}$ of 1 M HEPES-KOH ( $\mathrm{pH} 7.5), 100 \mu \mathrm{L}$ of $0.5 \mathrm{M}$ EDTA (pH 8.0), $50 \mathrm{~mL}$ of glycerol, $25 \mu \mathrm{L}$ of $200 \mathrm{mM}$ GDP, and $500 \mu \mathrm{L}$ of $1 \mathrm{M}$ DTT, and then, add RNase-free water up to $500 \mathrm{~mL}$. Add GDP immediately before use.

HiTrap Q B buffer: 20 mM HEPES-KOH (pH 7.5), $1 \mathrm{M} \mathrm{KCl,} 0.1 \mathrm{mM}$ EDTA, 10\% (vol/vol) glycerol, $10 \mu \mathrm{M}$ GDP, and $1 \mathrm{mM}$ DTT. Mix $10 \mathrm{~mL}$ of $1 \mathrm{M}$ HEPES-KOH (pH 7.5), $37.3 \mathrm{~g}$ of $\mathrm{KCl}, 100 \mu \mathrm{L}$ of $0.5 \mathrm{M}$ EDTA (pH 8.0), $50 \mathrm{~mL}$ of glycerol, $25 \mu \mathrm{L}$ of $200 \mathrm{mM} \mathrm{GDP}$, and $500 \mu \mathrm{L}$ of $1 \mathrm{M}$ DTT, and then, add RNase-free water up to $500 \mathrm{~mL}$. Add GDP immediately before use. Stock buffer: $20 \mathrm{mM}$ HEPES-KOH (pH 7.5), $100 \mathrm{mM} \mathrm{KCl,} \mathrm{10 \%} \mathrm{(vol/vol)} \mathrm{glycerol,} 10 \mu \mathrm{M}$ GDP, and $1 \mathrm{mM}$ DTT. Mix $20 \mathrm{~mL}$ of 1 M HEPES-KOH (pH 7.5), 7.46 g of KCl, $100 \mathrm{~mL}$ of glycerol, $50 \mu \mathrm{L}$ of $200 \mathrm{mM}$ GDP, and $1 \mathrm{~mL}$ of $1 \mathrm{M}$ DTT, and then, add RNase-free water up to $1 \mathrm{~L}$. Add GDP immediately before use.

\subsection{3. eEF3 Preparation}

Lysis buffer: $50 \mathrm{mM}$ HEPES-KOH (pH 7.5), $500 \mathrm{mM} \mathrm{KCl,} \mathrm{10 \%} \mathrm{(vol/vol)} \mathrm{glycerol,} 0.2 \mathrm{mM}$ PMSF, and $7 \mathrm{mM} \beta$-Me. Mix $50 \mathrm{~mL}$ of 1 M HEPES-KOH (pH 7.5), $37.3 \mathrm{~g}$ of KCl, $100 \mathrm{~mL}$ of glycerol, $2 \mathrm{~mL}$ of $100 \mathrm{mM}$ PMSF, and $500 \mu \mathrm{L}$ of $14 \mathrm{M} \beta$-Me, and then, add RNase-free water up to $1 \mathrm{~L}$. Add 1 tablet of complete mini protease inhibitor cocktail (Roche) per $50 \mathrm{~mL}$ of buffer.

Ni-NTA wash buffer: $50 \mathrm{mM}$ HEPES-KOH (pH 7.5), $1 \mathrm{M} \mathrm{KCl}, 20 \mathrm{mM}$ Imidazole, $10 \%$ (vol/vol) glycerol, $0.2 \mathrm{mM}$ PMSF, and $3.5 \mathrm{mM} \beta$-Me. Mix $17.5 \mathrm{~mL}$ of $1 \mathrm{M}$ HEPES-KOH (pH 7.5), $26.1 \mathrm{~g}$ of $\mathrm{KCl}, 2.8 \mathrm{~mL}$ of $2.5 \mathrm{M}$ Imidazole (pH 7.5), $35 \mathrm{~mL}$ of glycerol, $700 \mu \mathrm{L}$ of $100 \mathrm{mM}$ PMSF, and $87.5 \mu \mathrm{L}$ of $14 \mathrm{M} \beta-\mathrm{Me}$, and then, add RNase-free water up to $350 \mathrm{~mL}$.

Ni-NTA elution buffer: $50 \mathrm{mM}$ HEPES-KOH (pH 7.5), $100 \mathrm{mM} \mathrm{KCl}, 250 \mathrm{mM}$ Imidazole, $10 \%$ (vol/vol) glycerol, $0.2 \mathrm{mM}$ PMSF, and $3.5 \mathrm{mM} \beta$-Me. Mix $1 \mathrm{~mL}$ of $1 \mathrm{M}$ HEPES-KOH (pH 7.5), $149 \mathrm{mg}$ of KCl, $340 \mathrm{mg}$ of solid Imidazole, $2 \mathrm{~mL}$ of glycerol, $40 \mu \mathrm{L}$ of $100 \mathrm{mM}$ PMSF, and $5 \mu \mathrm{L}$ of $14 \mathrm{M} \beta-\mathrm{Me}$, and then, add RNase-free water up to $20 \mathrm{~mL}$.

Dialysis buffer: $20 \mathrm{mM}$ HEPES-KOH (pH 7.5), $150 \mathrm{mM} \mathrm{KCl}, 0.1 \mathrm{mM}$ EDTA, 10\% (vol/vol) glycerol, and $7 \mathrm{mM} \beta$-Me. Mix $20 \mathrm{~mL}$ of 1 M HEPES-KOH (pH 7.5), $11.2 \mathrm{~g}$ of $\mathrm{KCl}, 200 \mu \mathrm{L}$ of $0.5 \mathrm{M}$ EDTA (pH 8.0), $100 \mathrm{~mL}$ of glycerol, and $500 \mu \mathrm{L}$ of $14 \mathrm{M} \beta-\mathrm{Me}$, and then, add RNase-free water up to $1 \mathrm{~L}$.

HiTrap Q A buffer: $20 \mathrm{mM}$ HEPES-KOH (pH 7.5), 10\% (vol/vol) glycerol, and $5 \mathrm{mM} \beta-\mathrm{Me}$. Mix $10 \mathrm{~mL}$ of $1 \mathrm{M}$ HEPES-KOH (pH 7.5), $50 \mathrm{~mL}$ of glycerol, and $179 \mu \mathrm{L}$ of $14 \mathrm{M} \beta-\mathrm{Me}$, and then, add RNase-free water up to $500 \mathrm{~mL}$.

HiTrap Q B buffer: $20 \mathrm{mM}$ HEPES-KOH (pH 7.5), $1 \mathrm{M} \mathrm{KCl}, 10 \%$ (vol/vol) glycerol, and $5 \mathrm{mM} \beta$-Me. Mix $10 \mathrm{~mL}$ of 1 M HEPES-KOH (pH 7.5), $37.3 \mathrm{~g}$ of KCl, $50 \mathrm{~mL}$ of glycerol, and $179 \mu \mathrm{L}$ of $14 \mathrm{M} \beta-\mathrm{Me}$, and then, add RNase-free water up to $500 \mathrm{~mL}$.

Stock buffer: $20 \mathrm{mM}$ HEPES-KOH (pH 7.5), $100 \mathrm{mM} \mathrm{KCl}, 10 \%$ (vol/vol) glycerol, and $3.5 \mathrm{mM} \beta$-Me. Mix $20 \mathrm{~mL}$ of 1 M HEPES-KOH (pH 7.5), 7.46 $\mathrm{g}$ of $\mathrm{KCl}, 100 \mathrm{~mL}$ of glycerol, and $250 \mu \mathrm{L}$ of $14 \mathrm{M} \beta-\mathrm{Me}$, and then, add RNase-free water up to $1 \mathrm{~L}$.

\subsection{4. eRF1 Preparation}

Lysis buffer: $50 \mathrm{mM}$ Tris- $\mathrm{HCl}$ (pH 7.5), $100 \mathrm{mM} \mathrm{KCl}, 10 \%$ (vol/vol) glycerol, $0.1 \mathrm{mM} \mathrm{PMSF}$, and $3.5 \mathrm{mM} \beta$-Me. Mix $50 \mathrm{~mL}$ of $1 \mathrm{M}$ Tris- $\mathrm{HCl}$ (pH 7.5), $7.46 \mathrm{~g}$ of $\mathrm{KCl}, 100 \mathrm{~mL}$ of glycerol, 
$1 \mathrm{~mL}$ of $100 \mathrm{mM}$ PMSF, and $250 \mu \mathrm{L}$ of $14 \mathrm{M} \beta-\mathrm{Me}$, and then, add RNase-free water up to $1 \mathrm{~L}$. Add 1 tablet of complete mini protease inhibitor cocktail (Roche) per $50 \mathrm{~mL}$ of buffer. Ni-NTA wash buffer: $50 \mathrm{mM}$ Tris- $\mathrm{HCl}(\mathrm{pH} 7.5), 1 \mathrm{M} \mathrm{NH}{ }_{4} \mathrm{Cl}, 10 \mathrm{mM}$ Imidazole, 10\% (vol/vol) glycerol, and $3.5 \mathrm{mM} \beta-\mathrm{Me}$. Mix $25 \mathrm{~mL}$ of $1 \mathrm{M}$ Tris- $\mathrm{HCl}(\mathrm{pH} 7.5), 26.7 \mathrm{~g}$ of $\mathrm{NH}_{4} \mathrm{Cl}$, $2 \mathrm{~mL}$ of $2.5 \mathrm{M}$ Imidazole (pH 7.5), $50 \mathrm{~mL}$ of glycerol, and $125 \mu \mathrm{L}$ of $14 \mathrm{M} \beta-\mathrm{Me}$, and then, add RNase-free water up to $500 \mathrm{~mL}$.

Ni-NTA elution buffer: 50 mM Tris-HCl (pH 7.5), 100 mM KCl, 200 mM Imidazole, 10\% (vol/vol) glycerol, and $3.5 \mathrm{mM} \beta-\mathrm{Me}$. Mix $1.5 \mathrm{~mL}$ of $1 \mathrm{M}$ Tris- $\mathrm{HCl}$ (pH 7.5), $224 \mathrm{mg}$ of $\mathrm{KCl}, 408 \mathrm{mg}$ of solid imidazole, $3 \mathrm{~mL}$ of glycerol, and $7.5 \mu \mathrm{L}$ of $14 \mathrm{M} \beta-\mathrm{Me}$, and then, add RNase-free water up to $30 \mathrm{~mL}$.

HiTrap Q A buffer: 20 mM HEPES-KOH (pH 7.5), 10\% (vol/vol) glycerol, and 7 mM $\beta$-Me. Mix $20 \mathrm{~mL}$ of 1 M HEPES-KOH (pH 7.5), $100 \mathrm{~mL}$ of glycerol, and $500 \mu \mathrm{L}$ of $14 \mathrm{M} \beta-\mathrm{Me}$, and then, add RNase-free water up to $1 \mathrm{~L}$.

HiTrap Q B buffer: 20 mM HEPES-KOH (pH 7.5), $1 \mathrm{M} \mathrm{KCl,10 \%} \mathrm{(vol/vol)} \mathrm{glycerol,} \mathrm{and}$ $7 \mathrm{mM} \beta$-Me. Mix $20 \mathrm{~mL}$ of 1 M HEPES-KOH (pH 7.5), $74.6 \mathrm{~g}$ of $\mathrm{KCl}, 100 \mathrm{~mL}$ of glycerol, and $500 \mu \mathrm{L}$ of $14 \mathrm{M} \beta-\mathrm{Me}$, and then, add RNase-free water up to $1 \mathrm{~L}$.

Stock buffer: $20 \mathrm{mM}$ HEPES-KOH (pH 7.5), $100 \mathrm{mM} \mathrm{KCl,10 \%} \mathrm{(vol/vol)} \mathrm{glycerol,} \mathrm{and}$ $7 \mathrm{mM} \beta$-Me. Mix $20 \mathrm{~mL}$ of 1 M HEPES-KOH (pH 7.5), $7.46 \mathrm{~g}$ of KCl, $100 \mathrm{~mL}$ of glycerol, and $500 \mu \mathrm{L}$ of $14 \mathrm{M} \beta-\mathrm{Me}$, and then, add RNase-free water up to $1 \mathrm{~L}$.

\subsection{5. eRF3 $\Delta 165$ Preparation}

Lysis buffer: $50 \mathrm{mM}$ Tris- $\mathrm{HCl}$ ( $\mathrm{pH} 7.5), 100 \mathrm{mM} \mathrm{KCl}, 7 \mathrm{mM} \mathrm{MgCl}$, $10 \mathrm{mM}$ imidazole, 10\% (vol/vol) glycerol, $50 \mu \mathrm{M}$ GDP, $0.1 \mathrm{mM}$ PMSF, and $3.5 \mathrm{mM} \beta-\mathrm{Me}$. Mix $50 \mathrm{~mL}$ of $1 \mathrm{M}$ Tris- $\mathrm{HCl}$ (pH 7.5), $7.46 \mathrm{~g}$ of $\mathrm{KCl}, 7 \mathrm{~mL}$ of $1 \mathrm{M} \mathrm{MgCl}_{2}, 4 \mathrm{~mL}$ of $2.5 \mathrm{M}$ imidazole (pH 7.5), $100 \mathrm{~mL}$ of glycerol, $250 \mu \mathrm{L}$ of $200 \mathrm{mM}$ GDP, $1 \mathrm{~mL}$ of $100 \mathrm{mM}$ PMSF, and $250 \mu \mathrm{L}$ of $14 \mathrm{M}$ $\beta-\mathrm{Me}$, and then, add RNase-free water up to $1 \mathrm{~L}$. Add 1 tablet of complete mini protease inhibitor cocktail (Roche) per $50 \mathrm{~mL}$ of buffer. Add GDP immediately before use.

Ni-NTA wash buffer: $50 \mathrm{mM}$ Tris- $\mathrm{HCl}$ (pH 7.5), $1 \mathrm{M} \mathrm{NH} 4 \mathrm{Cl}, 7 \mathrm{mM} \mathrm{MgCl}, 10 \mathrm{mM}$ imidazole, 10\% (vol/vol) glycerol, $50 \mu \mathrm{M}$ GDP, and $3.5 \mathrm{mM} \beta$-Me. Mix $25 \mathrm{~mL}$ of $1 \mathrm{M}$ Tris- $\mathrm{HCl}$ (pH 7.5), $26.7 \mathrm{~g}$ of $\mathrm{NH}_{4} \mathrm{Cl}, 3.5 \mathrm{~mL}$ of $1 \mathrm{M} \mathrm{MgCl}_{2}, 2 \mathrm{~mL}$ of $2.5 \mathrm{M}$ imidazole (pH 7.5), $50 \mathrm{~mL}$ of glycerol, $125 \mu \mathrm{L}$ of $200 \mathrm{mM}$ GDP, and $125 \mu \mathrm{L}$ of $14 \mathrm{M} \beta-\mathrm{Me}$, and then, add RNase-free water up to $500 \mathrm{~mL}$. Add GDP immediately before use.

Ni-NTA elution buffer: $50 \mathrm{mM}$ Tris- $\mathrm{HCl}$ (pH 7.5), $100 \mathrm{mM} \mathrm{KCl,} 7 \mathrm{mM} \mathrm{MgCl}$, $150 \mathrm{mM}$ imidazole, 10\% (vol/vol) glycerol, $50 \mu \mathrm{M}$ GDP, and $3.5 \mathrm{mM} \beta-\mathrm{Me}$. Mix $1.5 \mathrm{~mL}$ of $1 \mathrm{M}$ Tris- $\mathrm{HCl}$ (pH 7.5), $224 \mathrm{mg}$ of $\mathrm{KCl}, 210 \mu \mathrm{L}$ of $1 \mathrm{M} \mathrm{MgCl}_{2}, 306 \mathrm{mg}$ of solid imidazole, $3 \mathrm{~mL}$ of glycerol, $7.5 \mu \mathrm{L}$ of $200 \mathrm{mM}$ GDP, and $7.5 \mu \mathrm{L}$ of $14 \mathrm{M} \beta-\mathrm{Me}$, and then, add RNase-free water up to $30 \mathrm{~mL}$. Add GDP immediately before use.

HiTrap Q A buffer: 20 mM HEPES-KOH (pH 7.5), $1 \mathrm{mM} \mathrm{MgCl} 2,0.1 \mathrm{mM}$ EDTA, 10\% (vol/vol) glycerol, $50 \mu \mathrm{M}$ GDP and $7 \mathrm{mM} \beta$-Me. Mix $20 \mathrm{~mL}$ of $1 \mathrm{M}$ HEPES-KOH (pH 7.5), $1 \mathrm{~mL}$ of $1 \mathrm{M} \mathrm{MgCl}_{2}, 200 \mu \mathrm{L}$ of $0.5 \mathrm{M}$ EDTA (pH 8.0), $100 \mathrm{~mL}$ of glycerol, $250 \mu \mathrm{L}$ of $200 \mathrm{mM}$ GDP, and $500 \mu \mathrm{L}$ of $14 \mathrm{M} \beta-\mathrm{Me}$, and then, add RNase-free water up to $1 \mathrm{~L}$. Add GDP immediately before use.

HiTrap Q B buffer: 20 mM HEPES-KOH (pH 7.5), $1 \mathrm{M} \mathrm{KCl,} 1 \mathrm{mM} \mathrm{MgCl}, 0.1 \mathrm{mM}$ EDTA, $10 \%$ (vol/vol) glycerol, $50 \mu \mathrm{M}$ GDP and $7 \mathrm{mM} \beta-\mathrm{Me}$. Mix $20 \mathrm{~mL}$ of $1 \mathrm{M}$ HEPES-KOH (pH 7.5), $74.6 \mathrm{~g}$ of $\mathrm{KCl}, 1 \mathrm{~mL}$ of $1 \mathrm{M} \mathrm{MgCl}_{2}, 200 \mu \mathrm{L}$ of $0.5 \mathrm{M}$ EDTA (pH 8.0), $100 \mathrm{~mL}$ of glycerol, $250 \mu \mathrm{L}$ of $200 \mathrm{mM}$ GDP, and $500 \mu \mathrm{L}$ of $14 \mathrm{M} \beta-\mathrm{Me}$, and then, add RNase-free water up to $1 \mathrm{~L}$. Add GDP immediately before use.

Stock buffer: 20 mM HEPES-KOH (pH 7.5), $100 \mathrm{mM} \mathrm{KCl,} 1 \mathrm{mM} \mathrm{MgCl} 2,0.1 \mathrm{mM}$ EDTA, 10\% (vol/vol) glycerol, $50 \mu \mathrm{M}$ GDP and $7 \mathrm{mM} \beta$-Me. Mix $20 \mathrm{~mL}$ of $1 \mathrm{M}$ HEPES-KOH (pH 7.5), $7.46 \mathrm{~g}$ of $\mathrm{KCl}, 1 \mathrm{~mL}$ of $1 \mathrm{M} \mathrm{MgCl}_{2}, 200 \mu \mathrm{L}$ of $0.5 \mathrm{M}$ EDTA (pH 8.0), $100 \mathrm{~mL}$ of glycerol, $250 \mu \mathrm{L}$ of $200 \mathrm{mM}$ GDP, and $500 \mu \mathrm{L}$ of $14 \mathrm{M} \beta-\mathrm{Me}$, and then, add RNase-free water up to $1 \mathrm{~L}$. Add GDP immediately before use. 


\subsubsection{Dom34 Preparation}

Lysis buffer: $50 \mathrm{mM}$ Tris- $\mathrm{HCl}$ (pH 7.5), $100 \mathrm{mM} \mathrm{KCl}, 10 \%$ (vol/vol) glycerol, $0.1 \mathrm{mM}$ PMSF, and $3.5 \mathrm{mM} \beta$-Me. Mix $50 \mathrm{~mL}$ of $1 \mathrm{M}$ Tris- $\mathrm{HCl}(\mathrm{pH} 7.5), 7.46 \mathrm{~g}$ of $\mathrm{KCl}, 100 \mathrm{~mL}$ of glycerol, $1 \mathrm{~mL}$ of $100 \mathrm{mM} \mathrm{PMSF}$, and $250 \mu \mathrm{L}$ of $14 \mathrm{M} \beta-\mathrm{Me}$, and then, add RNase-free water up to $1 \mathrm{~L}$. Add 1 tablet of complete mini protease inhibitor cocktail (Roche) per $50 \mathrm{~mL}$ of buffer. Ni-NTA wash buffer: $50 \mathrm{mM}$ Tris- $\mathrm{HCl}\left(\mathrm{pH}\right.$ 7.5), $1 \mathrm{M} \mathrm{NH}_{4} \mathrm{Cl}, 10 \mathrm{mM}$ Imidazole, $10 \%$ (vol/vol) glycerol, and $3.5 \mathrm{mM} \beta$-Me. Mix $25 \mathrm{~mL}$ of $1 \mathrm{M}$ Tris- $\mathrm{HCl}$ (pH 7.5), $26.7 \mathrm{~g}$ of $\mathrm{NH}_{4} \mathrm{Cl}$, $2 \mathrm{~mL}$ of $2.5 \mathrm{M}$ Imidazole (pH 7.5), $50 \mathrm{~mL}$ of glycerol, and $125 \mu \mathrm{L}$ of $14 \mathrm{M} \beta-\mathrm{Me}$, and then, add RNase-free water up to $500 \mathrm{~mL}$.

Ni-NTA elution buffer: $50 \mathrm{mM}$ Tris- $\mathrm{HCl}$ (pH 7.5), $100 \mathrm{mM} \mathrm{KCl,} 200 \mathrm{mM}$ Imidazole, 10\% (vol/vol) glycerol, and $3.5 \mathrm{mM} \beta-\mathrm{Me}$. Mix $1.5 \mathrm{~mL}$ of $1 \mathrm{M}$ Tris- $\mathrm{HCl}(\mathrm{pH} 7.5), 224 \mathrm{mg}$ of $\mathrm{KCl}, 408 \mathrm{mg}$ of solid imidazole, $3 \mathrm{~mL}$ of glycerol, and $7.5 \mu \mathrm{L}$ of $14 \mathrm{M} \beta-\mathrm{Me}$, and then, add RNase-free water up to $30 \mathrm{~mL}$.

HiTrap Q A buffer: $20 \mathrm{mM}$ HEPES-KOH (pH 7.5), $10 \%$ (vol/vol) glycerol, and $7 \mathrm{mM} \beta$-Me. Mix $20 \mathrm{~mL}$ of $1 \mathrm{M}$ HEPES-KOH (pH 7.5), $100 \mathrm{~mL}$ of glycerol, and $500 \mu \mathrm{L}$ of $14 \mathrm{M} \beta-\mathrm{Me}$, and then, add RNase-free water up to $1 \mathrm{~L}$.

HiTrap Q B buffer: $20 \mathrm{mM}$ HEPES-KOH ( $\mathrm{pH} 7.5), 1 \mathrm{M} \mathrm{KCl}, 10 \%$ (vol/vol) glycerol, and $7 \mathrm{mM} \beta$-Me. Mix $20 \mathrm{~mL}$ of 1 M HEPES-KOH (pH 7.5), $74.6 \mathrm{~g}$ of $\mathrm{KCl}, 100 \mathrm{~mL}$ of glycerol, and $500 \mu \mathrm{L}$ of $14 \mathrm{M} \beta-\mathrm{Me}$, and then, add RNase-free water up to $1 \mathrm{~L}$.

Stock buffer: $20 \mathrm{mM}$ HEPES-KOH (pH 7.5), $200 \mathrm{mM} \mathrm{KCl}, 10 \%$ (vol/vol) glycerol, and $7 \mathrm{mM} \beta$-Me. Mix $20 \mathrm{~mL}$ of 1 M HEPES-KOH (pH 7.5), $14.9 \mathrm{~g}$ of $\mathrm{KCl}, 100 \mathrm{~mL}$ of glycerol, and $500 \mu \mathrm{L}$ of $14 \mathrm{M} \beta-\mathrm{Me}$, and then, add RNase-free water up to $1 \mathrm{~L}$.

\subsubsection{Hbs1 Preparation}

Lysis buffer: $50 \mathrm{mM}$ Tris- $\mathrm{HCl}$ (pH 7.5), $100 \mathrm{mM} \mathrm{KCl}, 7 \mathrm{mM} \mathrm{MgCl} 2,10 \mathrm{mM}$ imidazole, $10 \%$ (vol/vol) glycerol, $50 \mu \mathrm{M}$ GDP, $0.1 \mathrm{mM}$ PMSF, and $3.5 \mathrm{mM} \beta$-Me. Mix $50 \mathrm{~mL}$ of $1 \mathrm{M}$ Tris- $\mathrm{HCl}$ ( $\mathrm{pH} 7.5), 7.46 \mathrm{~g}$ of $\mathrm{KCl}, 7 \mathrm{~mL}$ of $1 \mathrm{M} \mathrm{MgCl}_{2}, 4 \mathrm{~mL}$ of $2.5 \mathrm{M}$ imidazole ( $\mathrm{pH} 7.5$ ), $100 \mathrm{~mL}$ of glycerol, $250 \mu \mathrm{L}$ of $200 \mathrm{mM}$ GDP, $1 \mathrm{~mL}$ of $100 \mathrm{mM}$ PMSF, and $250 \mu \mathrm{L}$ of $14 \mathrm{M}$ $\beta-\mathrm{Me}$, and then, add RNase-free water up to $1 \mathrm{~L}$. Add 1 tablet of complete mini protease inhibitor cocktail (Roche) per $50 \mathrm{~mL}$ of buffer. Add GDP immediately before use.

Ni-NTA wash buffer: $50 \mathrm{mM}$ Tris- $\mathrm{HCl}$ ( $\mathrm{pH}$ 7.5), $1 \mathrm{M} \mathrm{NH}_{4} \mathrm{Cl}, 7 \mathrm{mM} \mathrm{MgCl} 2,10 \mathrm{mM}$ imidazole, $10 \%$ (vol/vol) glycerol, $50 \mu \mathrm{M}$ GDP, and $3.5 \mathrm{mM} \beta$-Me. Mix $15 \mathrm{~mL}$ of $1 \mathrm{M}$ Tris- $\mathrm{HCl}$ ( $\mathrm{pH} 7.5$ ), $16 \mathrm{~g}$ of $\mathrm{NH}_{4} \mathrm{Cl}, 2.1 \mathrm{~mL}$ of $1 \mathrm{M} \mathrm{MgCl}_{2}, 1.2 \mathrm{~mL}$ of $2.5 \mathrm{M}$ imidazole (pH 7.5), $30 \mathrm{~mL}$ of glycerol, $75 \mu \mathrm{L}$ of $200 \mathrm{mM} \mathrm{GDP}$, and $75 \mu \mathrm{L}$ of $14 \mathrm{M} \beta-\mathrm{Me}$, and then, add RNase-free water up to $300 \mathrm{~mL}$. Add GDP immediately before use.

Ni-NTA elution buffer: $50 \mathrm{mM}$ Tris- $\mathrm{HCl}$ (pH 7.5), $100 \mathrm{mM} \mathrm{KCl}, 7 \mathrm{mM} \mathrm{MgCl} 2,150 \mathrm{mM}$ imidazole, $10 \%$ (vol/vol) glycerol, $50 \mu \mathrm{M}$ GDP, and $3.5 \mathrm{mM} \beta$-Me. Mix $1 \mathrm{~mL}$ of $1 \mathrm{M}$ Tris- $\mathrm{HCl}$ (pH 7.5), $149 \mathrm{mg}$ of KCl, $140 \mu \mathrm{L}$ of $1 \mathrm{M} \mathrm{MgCl}_{2}, 204 \mathrm{mg}$ of solid imidazole, $2 \mathrm{~mL}$ of glycerol, $5 \mu \mathrm{L}$ of $200 \mathrm{mM}$ GDP, and $5 \mu \mathrm{L}$ of $14 \mathrm{M} \beta$-Me, and then, add RNase-free water up to $20 \mathrm{~mL}$. Add GDP immediately before use.

Mono Q A buffer: $20 \mathrm{mM}$ HEPES-KOH (pH 7.5), $1 \mathrm{mM} \mathrm{MgCl} 2,0.1 \mathrm{mM}$ EDTA, 10\% (vol/vol) glycerol, $50 \mu \mathrm{M}$ GDP and $7 \mathrm{mM} \beta$-Me. Mix $20 \mathrm{~mL}$ of 1 M HEPES-KOH (pH 7.5), $1 \mathrm{~mL}$ of $1 \mathrm{M} \mathrm{MgCl}_{2}, 200 \mu \mathrm{L}$ of $0.5 \mathrm{M}$ EDTA (pH 8.0), $100 \mathrm{~mL}$ of glycerol, $250 \mu \mathrm{L}$ of $200 \mathrm{mM}$ GDP, and $500 \mu \mathrm{L}$ of $14 \mathrm{M} \beta-\mathrm{Me}$, and then, add RNase-free water up to $1 \mathrm{~L}$. Add GDP immediately before use.

HiTrap Q B buffer: 20 mM HEPES-KOH (pH 7.5), $1 \mathrm{M} \mathrm{KCl}, 1 \mathrm{mM} \mathrm{MgCl}, 0.1 \mathrm{mM}$ EDTA, $10 \%$ (vol/vol) glycerol, $50 \mu \mathrm{M}$ GDP and $7 \mathrm{mM} \beta$-Me. Mix $20 \mathrm{~mL}$ of $1 \mathrm{M}$ HEPES-KOH ( $\mathrm{pH}$ 7.5), $74.6 \mathrm{~g}$ of $\mathrm{KCl}, 1 \mathrm{~mL}$ of $1 \mathrm{M} \mathrm{MgCl}_{2}, 200 \mu \mathrm{L}$ of $0.5 \mathrm{M}$ EDTA (pH 8.0), $100 \mathrm{~mL}$ of glycerol, $250 \mu \mathrm{L}$ of $200 \mathrm{mM}$ GDP, and $500 \mu \mathrm{L}$ of $14 \mathrm{M} \beta-\mathrm{Me}$, and then, add RNase-free water up to $1 \mathrm{~L}$. Add GDP immediately before use.

Stock buffer: $20 \mathrm{mM}$ HEPES-KOH (pH 7.5), $100 \mathrm{mM} \mathrm{KCl}, 1 \mathrm{mM} \mathrm{MgCl}_{2}, 0.1 \mathrm{mM}$ EDTA, $10 \%$ (vol/vol) glycerol, $50 \mu \mathrm{M}$ GDP and $7 \mathrm{mM} \beta$-Me. Mix $20 \mathrm{~mL}$ of 1 M HEPES-KOH (pH 7.5), $7.46 \mathrm{~g}$ of KCl, $1 \mathrm{~mL}$ of $1 \mathrm{M} \mathrm{MgCl}_{2}, 200 \mu \mathrm{L}$ of $0.5 \mathrm{M}$ EDTA (pH 8.0), $100 \mathrm{~mL}$ of 
glycerol, $250 \mu \mathrm{L}$ of $200 \mathrm{mM}$ GDP, and $500 \mu \mathrm{L}$ of $14 \mathrm{M} \beta-\mathrm{Me}$, and then, add RNase-free water up to $1 \mathrm{~L}$. Add GDP immediately before use.

\subsubsection{Rli1 Preparation}

Lysis buffer: $75 \mathrm{mM}$ HEPES-KOH (pH 7.5), $1 \mathrm{M} \mathrm{NH}_{4} \mathrm{Cl}, 20 \mathrm{mM}$ imidazole, 20\% (vol/vol) glycerol, $0.1 \mathrm{mM}$ PMSF, and $5 \mathrm{mM} \beta$-Me. Mix $75 \mathrm{~mL}$ of 1 M HEPES-KOH (pH 7.5), $53.5 \mathrm{~g}$ of $\mathrm{NH}_{4} \mathrm{Cl}, 8 \mathrm{~mL}$ of $2.5 \mathrm{M}$ imidazole (pH 7.5), $200 \mathrm{~mL}$ of glycerol, $1 \mathrm{~mL}$ of $100 \mathrm{mM}$ PMSF, and $357 \mu \mathrm{L}$ of $14 \mathrm{M} \beta-\mathrm{Me}$, and then, add RNase-free water up to $1 \mathrm{~L}$. Add 1 tablet of complete mini protease inhibitor cocktail (Roche) per $10 \mathrm{~mL}$ of buffer.

Ni-NTA wash buffer: $50 \mathrm{mM}$ HEPES-KOH ( $\mathrm{pH}$ 7.5), $1 \mathrm{M} \mathrm{NH}_{4} \mathrm{Cl}, 20 \mathrm{mM}$ imidazole, $20 \%$ (vol/vol) glycerol, and $5 \mathrm{mM} \beta$-Me. Mix $50 \mathrm{~mL}$ of 1 M HEPES-KOH ( $\mathrm{pH} 7.5$ ), $53.5 \mathrm{~g}$ of $\mathrm{NH}_{4} \mathrm{Cl}, 8 \mathrm{~mL}$ of $2.5 \mathrm{M}$ imidazole ( $\left.\mathrm{pH} 7.5\right), 200 \mathrm{~mL}$ of glycerol, and $357 \mu \mathrm{L}$ of $14 \mathrm{M} \beta-\mathrm{Me}$, and then, add RNase-free water up to $1 \mathrm{~L}$.

Ni-NTA wash buffer $+\mathbf{1} \%$ (vol/vol) TWEEN 20: Add $5 \mathrm{~mL}$ of TWEEN 20 to $500 \mathrm{~mL}$ of Ni-NTA wash buffer.

Ni-NTA elution buffer: $50 \mathrm{mM}$ HEPES-KOH (pH 7.5), $1 \mathrm{M} \mathrm{NH}_{4} \mathrm{Cl}, 300 \mathrm{mM}$ imidazole, $20 \%$ (vol/vol) glycerol, and $5 \mathrm{mM} \beta$-Me. Mix $2.5 \mathrm{~mL}$ of 1 M HEPES-KOH (pH 7.5), $2.67 \mathrm{~g}$ of $\mathrm{NH}_{4} \mathrm{Cl}, 1.02 \mathrm{~g}$ of solid imidazole, $10 \mathrm{~mL}$ of glycerol, and $17.9 \mu \mathrm{L}$ of $14 \mathrm{M} \beta-\mathrm{Me}$, and then, add RNase-free water up to $50 \mathrm{~mL}$.

HiTrap SP A buffer: $20 \mathrm{mM}$ MES-KOH (pH 6.6), $100 \mathrm{mM} \mathrm{KCl}, 0.1 \mathrm{mM}$ EDTA, 25\% (vol/vol) glycerol, and $7 \mathrm{mM} \beta-\mathrm{Me}$. Mix $10 \mathrm{~mL}$ of $1 \mathrm{M}$ MES-KOH (pH 6.6), $3.73 \mathrm{~g}$ of $\mathrm{KCl}, 100 \mu \mathrm{L}$ of $0.5 \mathrm{M}$ EDTA (pH 8.0), $125 \mathrm{~mL}$ of glycerol, and $250 \mu \mathrm{L}$ of $14 \mathrm{M} \beta-\mathrm{Me}$, and then, add RNase-free water up to $500 \mathrm{~mL}$.

HiTrap SP B buffer: $20 \mathrm{mM}$ MES-KOH (pH 6.6), $1 \mathrm{M} \mathrm{KCl}, 0.1 \mathrm{mM}$ EDTA, 25\% (vol/vol) glycerol, and $7 \mathrm{mM} \beta$-Me. Mix $10 \mathrm{~mL}$ of $1 \mathrm{M}$ MES-KOH (pH 6.6), $37.3 \mathrm{~g}$ of $\mathrm{KCl}, 100 \mu \mathrm{L}$ of $0.5 \mathrm{M}$ EDTA (pH 8.0), $125 \mathrm{~mL}$ of glycerol, and $250 \mu \mathrm{L}$ of $14 \mathrm{M} \beta-\mathrm{Me}$, and then, add RNase-free water up to $500 \mathrm{~mL}$.

Stock buffer: $20 \mathrm{mM}$ HEPES-KOH (pH 7.5), $200 \mathrm{mM} \mathrm{KCl}, 0.1 \mathrm{mM}$ EDTA, 25\% (vol/vol) glycerol, $0.1 \mathrm{mM}$ PMSF, and $7 \mathrm{mM} \beta$-Me. Mix $20 \mathrm{~mL}$ of 1 M HEPES-KOH (pH 7.5), $14.9 \mathrm{~g}$ of $\mathrm{KCl}, 200 \mu \mathrm{L}$ of $0.5 \mathrm{M}$ EDTA ( $\mathrm{pH} 8.0$ ), $250 \mathrm{~mL}$ of glycerol, $1 \mathrm{~mL}$ of $100 \mathrm{mM}$ PMSF, and $500 \mu \mathrm{L}$ of $14 \mathrm{M} \beta-\mathrm{Me}$, and then, add RNase-free water up to $1 \mathrm{~L}$.

\subsubsection{Ribosome Preparation}

Lysis buffer: 20 mM HEPES-KOH (pH 7.5), 100 mM KOAc (pH 7.5), $2.5 \mathrm{mM} \mathrm{Mg(OAc)})_{2}$, $0.5 \mathrm{mg} / \mathrm{mL}$ heparin, and $2 \mathrm{mM}$ DTT. Mix $20 \mathrm{~mL}$ of 1 M HEPES-KOH (pH 7.5), $33.3 \mathrm{~mL}$ of $3 \mathrm{M}$ KOAc (pH 7.5), $2.5 \mathrm{~mL}$ of $1 \mathrm{M} \mathrm{Mg}(\mathrm{OAc})_{2}, 5 \mathrm{~mL}$ of $100 \mathrm{mg} / \mathrm{mL}$ heparin, and $2 \mathrm{~mL}$ of $1 \mathrm{M}$ DTT, and then, add RNase-free water up to $1 \mathrm{~L}$. Add 1 tablet of complete mini protease inhibitor cocktail (Roche) per $10 \mathrm{~mL}$ of buffer. The requisite amount of the buffer is approximately $1.2 \mathrm{~L}$. Add heparin immediately before use.

Sucrose cushion Buffer I: $20 \mathrm{mM}$ HEPES-KOH (pH 7.5), $100 \mathrm{mM} \mathrm{KCl}, 20 \mathrm{mM} \mathrm{MgCl}$, $1 \mathrm{M}$ sucrose, $0.5 \mathrm{mg} / \mathrm{mL}$ heparin, $0.1 \mathrm{mM}$ PMSF, and $2 \mathrm{mM}$ DTT. Mix $500 \mu \mathrm{L}$ of $1 \mathrm{M}$ HEPES-KOH ( $\mathrm{pH} 7.5$ ), $186 \mathrm{mg}$ of $\mathrm{KCl}, 500 \mu \mathrm{L}$ of $1 \mathrm{M} \mathrm{MgCl}_{2}, 8.56 \mathrm{~g}$ of sucrose, $125 \mu \mathrm{L}$ of $100 \mathrm{mg} / \mathrm{mL}$ heparin, $25 \mu \mathrm{L}$ of $100 \mathrm{mM}$ PMSF, and $50 \mu \mathrm{L}$ of $1 \mathrm{M}$ DTT, and then, add RNase-free water up to $25 \mathrm{~mL}$. Add heparin immediately before use.

$>10 \mathrm{mM}$ puromycin: Dissolve $54.4 \mathrm{mg}$ of puromycin $\cdot 2 \mathrm{HCl}$ in $10 \mathrm{~mL}$ Puromycin treatment buffer. Store in approximately single-use aliquots $(310 \mu \mathrm{L})$ at $-80^{\circ} \mathrm{C}$.

Puromycin treatment buffer: $20 \mathrm{mM}$ HEPES-KOH (pH 7.5), $50 \mathrm{mM}\left(\mathrm{NH}_{4}\right)_{2} \mathrm{SO}_{4}, 20 \mathrm{mM}$ $\mathrm{MgCl}_{2}$, and $2 \mathrm{mM}$ DTT. Mix $200 \mu \mathrm{L}$ of 1 M HEPES-KOH (pH 7.5), $66.1 \mathrm{mg}$ of solid $\left(\mathrm{NH}_{4}\right)_{2} \mathrm{SO}_{4}, 200 \mu \mathrm{L}$ of $1 \mathrm{M} \mathrm{MgCl}_{2}$, and $20 \mu \mathrm{L}$ of $1 \mathrm{M} \mathrm{DTT}$, and then, add RNase-free water up to $10 \mathrm{~mL}$.

HiTrap Butyl A buffer: $20 \mathrm{mM}$ HEPES-KOH (pH 7.5), $1.4 \mathrm{M}\left(\mathrm{NH}_{4}\right)_{2} \mathrm{SO}_{4}, 50 \mathrm{mM} \mathrm{MgCl}$, and $2 \mathrm{mM}$ DTT. Mix $20 \mathrm{~mL}$ of 1 M HEPES-KOH (pH 7.5), $185 \mathrm{~g}$ of $\left(\mathrm{NH}_{4}\right)_{2} \mathrm{SO}_{4}, 50 \mathrm{~mL}$ of $1 \mathrm{M} \mathrm{MgCl}_{2}$, and $2 \mathrm{~mL}$ of $1 \mathrm{M} \mathrm{DTT}$, and then, add RNase-free water up to $1 \mathrm{~L}$. 
HiTrap Butyl B buffer: $20 \mathrm{mM}$ HEPES-KOH (pH 7.5), $20 \mathrm{mM} \mathrm{MgCl}$, and $2 \mathrm{mM}$ DTT. Mix $20 \mathrm{~mL}$ of $1 \mathrm{M}$ HEPES-KOH (pH 7.5), $20 \mathrm{~mL}$ of $1 \mathrm{M} \mathrm{MgCl}_{2}$, and $2 \mathrm{~mL}$ of $1 \mathrm{M} \mathrm{DTT}$, and then, add RNase-free water up to $1 \mathrm{~L}$.

Sucrose cushion Buffer II: 20 mM HEPES-KOH (pH 7.5), $100 \mathrm{mM} \mathrm{KCl}, 10 \mathrm{mM} \mathrm{MgCl}, 1 \mathrm{M}$ sucrose, and $2 \mathrm{mM}$ DTT. Mix $1 \mathrm{~mL}$ of 1 M HEPES-KOH (pH 7.5), $373 \mathrm{mg}$ of $\mathrm{KCl}, 500 \mu \mathrm{L}$ of $1 \mathrm{M} \mathrm{MgCl}_{2}, 17.1 \mathrm{~g}$ of sucrose, and $100 \mu \mathrm{L}$ of $1 \mathrm{M} \mathrm{DTT}$, and then, add RNase-free water up to $50 \mathrm{~mL}$.

5/100 buffer: 20 mM HEPES-KOH (pH 7.5), $100 \mathrm{mM} \mathrm{KCl,} 5 \mathrm{mM} \mathrm{MgCl} 2,0.25$ mM EDTA, and $2 \mathrm{mM}$ DTT. Mix $200 \mu \mathrm{L}$ of 1 M HEPES-KOH (pH 7.5), 74.6 mg of KCl, $50 \mu \mathrm{L}$ of $1 \mathrm{M}$ $\mathrm{MgCl}_{2}, 5 \mu \mathrm{L}$ of $0.5 \mathrm{M}$ EDTA (pH 8.0), and $20 \mu \mathrm{L}$ of $1 \mathrm{M} \mathrm{DTT}$, and then, add RNase-free water up to $10 \mathrm{~mL}$.

\subsubsection{0. tRNA Preparation}

Lysis buffer: 20 mM HEPES-KOH (pH 7.5), $100 \mathrm{mM} \mathrm{KOAc} \mathrm{(pH} \mathrm{7.5),} \mathrm{and} 2 \mathrm{mM} \mathrm{Mg}(\mathrm{OAc})_{2}$. Mix $20 \mathrm{~mL}$ of $1 \mathrm{M}$ HEPES-KOH (pH 7.5), $33.3 \mathrm{~mL}$ of $3 \mathrm{M} \mathrm{KOAc} \mathrm{(pH} \mathrm{7.5),} \mathrm{and} 2 \mathrm{~mL}$ of $1 \mathrm{M}$ $\mathrm{Mg}(\mathrm{OAc})_{2}$, and then, add RNase-free water up to $1 \mathrm{~L}$.

1 mM Tris-HCl (pH 7.5)-10 mM Mg(OAc) 2 : Mix $50 \mu \mathrm{L}$ of $1 \mathrm{M}$ Tris- $\mathrm{HCl}$ (pH 7.5) and $500 \mu \mathrm{L}$ of $1 \mathrm{M} \mathrm{Mg}(\mathrm{OAc})_{2}$, and then, add RNase-free water up to $50 \mathrm{~mL}$.

Phenol saturated with $1 \mathrm{mM}$ Tris- $\mathrm{HCl}\left(\mathrm{pH}\right.$ 7.5)-10 mM Mg(OAc) ${ }_{2}$ : Heat solid phenol at 50-60 ${ }^{\circ} \mathrm{C}$ until phenol dissolves completely. (i) Add an equal amount of $1 \mathrm{M}$ Tris- $\mathrm{HCl}$ ( $\mathrm{pH} 7.5$ ) to the phenol solution, mixing rigorously with a magnetic stirrer for about $1 \mathrm{~h}$ at room temperature. (ii) Remove the aqueous (upper) phase and measure the $\mathrm{pH}$ of the aqueous phase. Repeat steps (i) and (ii) until the $\mathrm{pH}$ reaches 7.5. (iii) Add an equal amount of $1 \mathrm{mM}$ Tris- $\mathrm{HCl}$ ( $\mathrm{pH} 7.5)-10 \mathrm{mM} \mathrm{Mg}(\mathrm{OAc})_{2}$ to the phenol solution, mixing rigorously with a magnetic stirrer for about $1 \mathrm{~h}$ at room temperature. (iv) Remove the aqueous (upper) phase and measure the $\mathrm{pH}$ of the aqueous phase. Repeat steps (iii) and (iv) twice, and check that the $\mathrm{pH}$ of the aqueous phase is 7.5. Remove the aqueous phase, leaving a small amount on top of the phenol. Store away from light at $4{ }^{\circ} \mathrm{C}$, where it usually remains stable for months.

HiTrap Q A buffer: $20 \mathrm{mM}$ Tris- $\mathrm{HCl}$ (pH 7.5), $200 \mathrm{mM} \mathrm{NaCl}, 8 \mathrm{mM} \mathrm{MgCl}$, and $0.1 \mathrm{mM}$ EDTA. Mix $20 \mathrm{~mL}$ of $1 \mathrm{M}$ Tris- $\mathrm{HCl}$ (pH 7.5), $11.7 \mathrm{~g}$ of $\mathrm{NaCl}, 8 \mathrm{~mL}$ of $1 \mathrm{M} \mathrm{MgCl}_{2}$, and $200 \mu \mathrm{L}$ of $0.5 \mathrm{M}$ EDTA ( $\mathrm{pH} 8.0$ ), and then, add RNase-free water up to $1 \mathrm{~L}$.

HiTrap Q B buffer: $20 \mathrm{mM}$ Tris- $\mathrm{HCl}$ (pH 7.5), $1 \mathrm{M} \mathrm{NaCl}, 8 \mathrm{mM} \mathrm{MgCl}$, and $0.1 \mathrm{mM}$ EDTA. Mix $20 \mathrm{~mL}$ of $1 \mathrm{M}$ Tris- $\mathrm{HCl}$ (pH 7.5), $58.4 \mathrm{~g}$ of $\mathrm{NaCl}, 8 \mathrm{~mL}$ of $1 \mathrm{M} \mathrm{MgCl}_{2}$, and $200 \mu \mathrm{L}$ of $0.5 \mathrm{M}$ EDTA (pH 8.0), and then, add RNase-free water up to $1 \mathrm{~L}$.

\subsubsection{Preparation of Aminoacyl-tRNAs}

Lysis buffer (for $\mathbf{S 1 0 0}$ preparation): $60 \mathrm{mM}$ Tris-OAc (pH 7.0), $50 \mathrm{mM} \mathrm{NH} \mathrm{mCl}_{4} 5 \mathrm{mM}$ $\mathrm{Mg}(\mathrm{OAc}) 2,0.1 \mathrm{mM}$ EDTA, 10\% (vol/vol) glycerol, $2 \mathrm{mM}$ spermidine, $0.1 \mathrm{mM}$ PMSF, and $10 \mathrm{mM} \beta$-Me. Mix $60 \mathrm{~mL}$ of $1 \mathrm{M}$ Tris-OAc ( $\mathrm{pH} 7.0), 2.7 \mathrm{~g}$ of $\mathrm{NH}_{4} \mathrm{Cl}, 5 \mathrm{~mL}$ of $1 \mathrm{M} \mathrm{Mg}(\mathrm{OAc})_{2}$, $200 \mu \mathrm{L}$ of $0.5 \mathrm{M}$ EDTA (pH 8.0), $100 \mathrm{~mL}$ of glycerol, $2 \mathrm{~mL}$ of $1 \mathrm{M}$ spermidine, $1 \mathrm{~mL}$ of $100 \mathrm{mM}$ PMSF, and $714 \mu \mathrm{L}$ of $14 \mathrm{M} \beta-\mathrm{Me}$, and then, add RNase-free water up to $1 \mathrm{~L}$. Add 1 tablet of complete mini protease inhibitor cocktail (Roche) per $10 \mathrm{~mL}$ of buffer. The requisite amount of the buffer is approximately 1.2 L. Add spermidine immediately before use.

Buffer A (for S100 preparation): $20 \mathrm{mM}$ HEPES-KOH (pH 8.0), $5 \mathrm{mM} \mathrm{NaCl}, 5 \mathrm{mM} \mathrm{MgCl} 2$, $0.1 \mathrm{mM}$ EDTA, 10\% (vol/vol) glycerol, $0.1 \mathrm{mM}$ PMSF, and $1 \mathrm{mM}$ DTT. Mix $20 \mathrm{~mL}$ of $1 \mathrm{M}$ HEPES-KOH (pH 8.0), $292 \mathrm{mg}$ of $\mathrm{NaCl}, 5 \mathrm{~mL}$ of $1 \mathrm{M} \mathrm{MgCl}_{2}, 200 \mu \mathrm{L}$ of $0.5 \mathrm{M}$ EDTA (pH 8.0), $100 \mathrm{~mL}$ of glycerol, $1 \mathrm{~mL}$ of $100 \mathrm{mM}$ PMSF, and $1 \mathrm{~mL}$ of 1 M DTT, and then, add RNase-free water up to $1 \mathrm{~L}$. Add 1 tablet of complete mini protease inhibitor cocktail (Roche) per $10 \mathrm{~mL}$ of buffer. The requisite amount of the buffer is approximately $4 \mathrm{~L}$.

Buffer A (250 mM NaCl) (for S100 preparation): 20 mM HEPES-KOH (pH 8.0), $250 \mathrm{mM}$ $\mathrm{NaCl}, 5 \mathrm{mM} \mathrm{MgCl} 2,0.1 \mathrm{mM}$ EDTA, 10\% (vol/vol) glycerol, $0.1 \mathrm{mM}$ PMSF, and $1 \mathrm{mM}$ DTT. Mix $2 \mathrm{~mL}$ of $1 \mathrm{M}$ HEPES-KOH (pH 8.0), $1.46 \mathrm{~g}$ of $\mathrm{NaCl}, 500 \mu \mathrm{L}$ of $1 \mathrm{M} \mathrm{MgCl}, 20 \mu \mathrm{L}$ of 
0.5 M EDTA (pH 8.0), $10 \mathrm{~mL}$ of glycerol, $100 \mu \mathrm{L}$ of $100 \mathrm{mM}$ PMSF, and $100 \mu \mathrm{L}$ of $1 \mathrm{M}$ DTT, and then, add RNase-free water up to $100 \mathrm{~mL}$. Add 1 tablet of complete mini protease inhibitor cocktail (Roche) per $10 \mathrm{~mL}$ of buffer.

Solution D: 4 M guanidine thiocyanate, $25 \mathrm{mM}$ sodium citrate ( $\mathrm{pH} 7.0$ ), 0.5\% (wt/vol) sarcosyl, and $85 \mathrm{mM} \beta$-Me. Mix $1.42 \mathrm{~g}$ of guanidine thiocyanate, $22.1 \mathrm{mg}$ of trisodium citrate dihydrate, $15 \mathrm{mg}$ of $\mathrm{N}$-Lauroylsarcosine sodium salt, and $18.2 \mu \mathrm{L}$ of $14 \mathrm{M} \beta-\mathrm{Me}$, and then, add RNase-free water up to $3 \mathrm{~mL}$. Prepare fresh before use.

Phenol saturated with $50 \mathrm{mM}$ KOAc (pH 5.5): Heat solid phenol at $50-60{ }^{\circ} \mathrm{C}$ until phenol dissolves completely. (i) Add an equal amount of $50 \mathrm{mM} \mathrm{KOAc} \mathrm{(pH} \mathrm{5.5)} \mathrm{to} \mathrm{the} \mathrm{phenol}$ solution, mixing rigorously with a magnetic stirrer for about $1 \mathrm{~h}$ at room temperature. (ii) Remove the aqueous (upper) phase and measure the $\mathrm{pH}$ of the aqueous phase. Repeat Steps (i) and (ii) until the $\mathrm{pH}$ reaches 5.5. Remove the aqueous phase, leaving a small amount on top of the phenol. Store away from light at $4{ }^{\circ} \mathrm{C}$, where it usually remains stable for months.

CIA (Chloroform:Isoamyl alcohol, 49:1): Mix $980 \mu \mathrm{L}$ of chloroform and $20 \mu \mathrm{L}$ of isoamyl alcohol.

0.3 M KOAc (pH 5.5)—5\% (vol/vol) isopropanol: Mix $2.5 \mathrm{~mL}$ of $3 \mathrm{M} \mathrm{KOAc} \mathrm{(pH} \mathrm{5.5)}$ and $1.25 \mathrm{~mL}$ of isopropanol, and then, add RNase-free water up to $25 \mathrm{~mL}$. Prepare fresh before use.

\subsubsection{In Vitro Translation}

$1.5 \mathrm{mM} 18$ a.a. (1.5 mM each 18 amino acids without Cys and Met): Mix $1.34 \mathrm{mg}$ of Ala, $2.61 \mathrm{mg}$ of Arg, $2.25 \mathrm{mg}$ of Asn, $2.00 \mathrm{mg}$ of Asp, $2.19 \mathrm{mg}$ of Gln, $2.21 \mathrm{mg}$ of Glu, $1.13 \mathrm{mg}$ of Gly, $2.33 \mathrm{mg}$ of His, $1.97 \mathrm{mg}$ of Ile, $1.97 \mathrm{mg}$ of Leu, $2.19 \mathrm{mg}$ of Lys, $2.48 \mathrm{mg}$ of Phe, $1.73 \mathrm{mg}$ of Pro, $1.58 \mathrm{mg}$ of Ser, $1.79 \mathrm{mg}$ of Thr, $3.06 \mathrm{mg}$ of Trp, $2.72 \mathrm{mg}$ of Tyr, and $1.76 \mathrm{mg}$ of Val, and then, add 0.1 M HEPES-KOH (pH 7.5) up to $10 \mathrm{~mL}$. Sterilize the solution with filtration. Store in approximately single-use aliquots $(20 \mu \mathrm{L})$ at $-80{ }^{\circ} \mathrm{C}$.

$10 \mathrm{mM}$ Cys: To $12.1 \mathrm{mg}$ of Cys, add RNase-free water up to $10 \mathrm{~mL}$. Sterilize the solution with filtration. Store in approximately single-use aliquots $(20 \mu \mathrm{L})$ at $-80^{\circ} \mathrm{C}$.

10x NTPs: Mix $200 \mu \mathrm{L}$ of $100 \mathrm{mM}$ ATP, $200 \mu \mathrm{L}$ of $100 \mathrm{mM}$ GTP, $100 \mu \mathrm{L}$ of $100 \mathrm{mM} \mathrm{CTP,}$ $100 \mu \mathrm{L}$ of $100 \mathrm{mM}$ UTP, and $400 \mu \mathrm{L}$ of RNase-free water. Sterilize the solution with filtration. Store in approximately single-use aliquots $(20 \mu \mathrm{L})$ at $-80^{\circ} \mathrm{C}$.

20 mM ATP, GTP: Mix $200 \mu \mathrm{L}$ of 100 mM ATP, $200 \mu \mathrm{L}$ of $100 \mathrm{mM}$ GTP, and $600 \mu \mathrm{L}$ of RNase-free water. Sterilize the solution with filtration. Store in approximately single-use aliquots $(20 \mu \mathrm{L})$ at $-80{ }^{\circ} \mathrm{C}$.

12\% PURE buffer (without Mg and SPD): Mix $1.5 \mathrm{~mL}$ of $1 \mathrm{M} \mathrm{HEPES-KOH} \mathrm{(pH} \mathrm{7.5),}$ $1.5 \mathrm{~mL}$ of $2 \mathrm{M}$ L-Glutamic acid potassium salt monohydrate, $30 \mu \mathrm{L}$ of $1 \mathrm{M} \mathrm{DTT}$, and $570 \mu \mathrm{L}$ of RNase-free water. Sterilize the solution with filtration. Store in approximately single-use aliquots $(20 \mu \mathrm{L})$ at $-80^{\circ} \mathrm{C}$.

2 M L-Glutamic acid potassium salt monohydrate: To $4.06 \mathrm{mg}$ of L-Glutamic acid potassium salt monohydrate, add RNase-free water up to $10 \mathrm{~mL}$. Sterilize the solution with filtration. Store at $-80{ }^{\circ} \mathrm{C}$.

1 M Creatine Phosphate: To $3.27 \mathrm{~g}$ of creatine phosphate, add RNase-free water up to $10 \mathrm{~mL}$. Sterilize the solution with filtration. Store in approximately single-use aliquots $(20 \mu \mathrm{L})$ at $-80^{\circ} \mathrm{C}$.

$250 \mathrm{mM} \mathrm{Mg}(\mathrm{OAc})_{2}$ : To $536 \mathrm{mg}$ of magnesium acetate tetrahydrate, add RNase-free water up to $10 \mathrm{~mL}$. Sterilize the solution with filtration. Store in approximately single-use aliquots $(20 \mu \mathrm{L})$ at $-80^{\circ} \mathrm{C}$.

1 M Spermidine: To $1.45 \mathrm{~g}$ of spermidine, add RNase-free water up to $10 \mathrm{~mL}$. Store at $-80{ }^{\circ} \mathrm{C}$.

$20 \mathrm{mM}$ Spermidine: Mix $200 \mu \mathrm{L}$ of $1 \mathrm{M}$ spermidine and $9.8 \mathrm{~mL}$ of RNase-free water. Store in approximately single-use aliquots $(20 \mu \mathrm{L})$ at $-80{ }^{\circ} \mathrm{C}$.

1 M Spermine: To $2.02 \mathrm{~g}$ of spermine, add RNase-free water up to $10 \mathrm{~mL}$. Store at $-80{ }^{\circ} \mathrm{C}$. 
$10 \mathrm{mM}$ Spermine: Mix $100 \mu \mathrm{L}$ of $1 \mathrm{M}$ spermine and $9.9 \mathrm{~mL}$ of RNase-free water. Store in approximately single-use aliquots $(20 \mu \mathrm{L})$ at $-80^{\circ} \mathrm{C}$.

$1 \mathrm{mM}$ Met: To $1.49 \mathrm{mg}$ of Met, add RNase-free water up to $10 \mathrm{~mL}$. Sterilize the solution with filtration. Store in approximately single-use aliquots $(20 \mu \mathrm{L})$ at $-80^{\circ} \mathrm{C}$.

5 mg/mL RNase A: To $7.5 \mathrm{mg}$ of RNaseA, add buffer (20 mM HEPES-KOH (pH 7.5), $\left.100 \mathrm{mM} \mathrm{KOAc}(\mathrm{pH} 7.5), 2 \mathrm{mM} \mathrm{Mg}(\mathrm{OAc})_{2}\right)$ up to $1.5 \mathrm{~mL}$. Store in aliquots $(50 \mu \mathrm{L})$ at $-30^{\circ} \mathrm{C}$. $0.1 \mathrm{mg} / \mathrm{mL}$ RNase A: Mix $200 \mu \mathrm{L}$ of $5 \mathrm{mg} / \mathrm{mL}$ RNase A and $9.8 \mathrm{~mL}$ of buffer $(20 \mathrm{mM}$ HEPES-KOH (pH 7.5), $\left.100 \mathrm{mM} \mathrm{KOAc} \mathrm{(pH} \mathrm{7.5),} 2 \mathrm{mM} \mathrm{Mg}(\mathrm{OAc})_{2}\right)$. Store in aliquots (1 mL) at $-30^{\circ} \mathrm{C}$.

\subsubsection{Cell Culture}

LB medium: Mix $10 \mathrm{~g}$ of bacto tryptone, $5 \mathrm{~g}$ of bacto yeast extract, and $10 \mathrm{~g}$ of $\mathrm{NaCl}$, and then, add water up to $1 \mathrm{~L}$. Thereafter, autoclave it.

2xYT medium: Mix $16 \mathrm{~g}$ of bacto tryptone, $10 \mathrm{~g}$ of bacto yeast extract, and $5 \mathrm{~g}$ of $\mathrm{NaCl}$, and then, add water up to $1 \mathrm{~L}$. Thereafter, autoclave it.

YPD medium: Mix $9 \mathrm{~g}$ of bacto yeast extract, $18 \mathrm{~g}$ of hipolypepton, and $18 \mathrm{~g}$ of $\mathrm{D}(+)-$ glucose, and then, add water up to $900 \mathrm{~mL}$. Thereafter, autoclave it. Bacto peptone (Thermo Fisher Scientific) can be used instead of hipolypepton (Wako).

SC-Ura medium containing $1 \%(\mathbf{w t} / \mathbf{v o l})$ raffinose: To prepare $400 \mathrm{~mL}$ of medium, mix $2.67 \mathrm{~g}$ of difco yeast nitrogen base without amino acids and $0.77 \mathrm{~g}$ of dropout mix without Ura, and then, add water up to $350 \mathrm{~mL}$. Add $1 \mathrm{M} \mathrm{NaOH}$ (approximately $4 \mathrm{~mL}$ ) into the medium, until the $\mathrm{pH}$ reaches $7-8$. After $\mathrm{pH}$ adjustment, add water up to $360 \mathrm{~mL}$ into the medium. Thereafter, autoclave it. Cool the medium to room temperature and add $40 \mathrm{~mL}$ of $10 \%$ (wt/vol) raffinose. To prepare $720 \mathrm{~mL}$ of medium, mix $5.33 \mathrm{~g}$ of difco yeast nitrogen base without amino acids and $1.54 \mathrm{~g}$ of dropout mix without Ura, and then, add water up to $600 \mathrm{~mL}$. Add $1 \mathrm{M} \mathrm{NaOH}$ (approximately $7 \mathrm{~mL}$ ) into the medium, until the $\mathrm{pH}$ reaches 7-8. After $\mathrm{pH}$ adjustment, add water up to $640 \mathrm{~mL}$ into the medium. Thereafter, autoclave it. Cool the medium to room temperature and add $80 \mathrm{~mL}$ of $10 \%(\mathrm{wt} / \mathrm{vol})$ raffinose.

$10 \%(\mathbf{w t} / \mathbf{v o l})$ raffinose: $\mathrm{To} 100 \mathrm{~g}$ of $\mathrm{D}(+)$-raffinose, add sterile water up to $1 \mathrm{~L}$. Sterilize the solution by filtration.

20\% (wt/vol) galactose: To $200 \mathrm{~g}$ of $\mathrm{D}(+)$-galactose, add sterile water up to $1 \mathrm{~L}$. Sterilize the solution by filtration.

Dropout mix without Ura: Mix $2 \mathrm{~g}$ of Adenine, $8 \mathrm{~g}$ of L-Inositol, $8 \mathrm{~g}$ of Ala, $8 \mathrm{~g}$ of Arg, $8 \mathrm{~g}$ of Asn, $8 \mathrm{~g}$ of Asp, $8 \mathrm{~g}$ of Cys, $8 \mathrm{~g}$ of Gln, $8 \mathrm{~g}$ of Glu, $8 \mathrm{~g}$ of Gly, $8 \mathrm{~g}$ of His, $8 \mathrm{~g}$ of Ile, $40 \mathrm{~g}$ of Leu, $8 \mathrm{~g}$ of Lys, $8 \mathrm{~g}$ of Met, $8 \mathrm{~g}$ of Phe, $8 \mathrm{~g}$ of Pro, $8 \mathrm{~g}$ of Ser, $8 \mathrm{~g}$ of Thr, $8 \mathrm{~g}$ of Trp, $8 \mathrm{~g}$ of Tyr, $8 \mathrm{~g}$ of Val, and $0.8 \mathrm{~g}$ of p-Aminobenzoic acid. Grind the mixture until a fine powder is formed. Store away from light at room temperature, where it usually remains stable for months.

\subsubsection{Others}

2x RNA loading dye: $0.05 \%$ (wt/vol) bromophenol blue (BPB), $0.05 \%$ (wt/vol) Xylene cyanole FF (XC), $0.5 \mathrm{mM}$ EDTA, and $7 \mathrm{M}$ urea. Mix $5 \mathrm{mg}$ of BPB, $5 \mathrm{mg}$ of XC, $10 \mu \mathrm{L}$ of $0.5 \mathrm{M}$ EDTA (pH 8.0), and $4.2 \mathrm{~g}$ of urea, and then, add RNase-free water up to $10 \mathrm{~mL}$. Can be stored at $-30{ }^{\circ} \mathrm{C}$.

$5 x$ LiDS dye: $5 \%$ (wt/vol) lithium dodecyl sulfate (LiDS), $25 \%$ (vol/vol) glycerol, $100 \mathrm{mM}$ Tris- $\mathrm{HCl}$ (pH 6.8), 0.025\% (wt/vol) BPB, and $875 \mathrm{mM} \beta$-Me. Mix $500 \mathrm{mg}$ of LiDS, $2.5 \mathrm{~mL}$ of glycerol, $1 \mathrm{~mL}$ of $1 \mathrm{M}$ Tris- $\mathrm{HCl}$ (pH 6.8), $2.5 \mathrm{mg}$ of BPB, and $625 \mu \mathrm{L}$ of $14 \mathrm{M} \beta-\mathrm{Me}$, and then, add RNase-free water up to $10 \mathrm{~mL}$. Can be stored at $-30^{\circ} \mathrm{C}$.

\section{Procedure}

\subsection{Preparation of Yeast Translation Factors}

All translation factors are checked for purity by SDS-PAGE analysis after purification (see [18] for the typical results). The concentrations of purified translation factors are determined by the Bradford Assay or by measuring the absorption spectrum and using 
the absorption coefficient (Table S1). The yields of the factors are summarized in Table S2. Verify the activities of the purified factors, according to Section 3.4.3, for the translation reaction method, and refer to Table S4 for the appropriate translation reaction condition for each translation factor.

\subsection{1. eEF1A}

\section{Cell culture}

1. From a glycerol stock, streak a sample of YPH499 yeast cells on a YPD plate and grow at $30^{\circ} \mathrm{C}$ for 2 days.

2. Collect the cells from the plate using a disposable loop, inoculate a $150 \mathrm{~mL}$ culture of YPD medium in a $500 \mathrm{~mL}$ flask with the cells, and then, grow overnight (approximately $16 \mathrm{~h}$ ) at $30^{\circ} \mathrm{C}$ with vigorous shaking at $170 \mathrm{rpm}$.

3. Inoculate six $900 \mathrm{~mL}$ culture of YPD medium in $2 \mathrm{~L}$ baffled flasks with $20 \mathrm{~mL}$ of the overnight culture per flask and grow at $30^{\circ} \mathrm{C}$ with vigorous shaking at $170 \mathrm{rpm}$ until the culture reaches an $\mathrm{OD}_{600}$ of 4.0. This should take approximately $9 \mathrm{~h}$.

4. Harvest the cells by centrifugation at $9000 \times g$ for $10 \mathrm{~min}$ at $4{ }^{\circ} \mathrm{C}$.

5. Resuspend with $1 \mathrm{~L}$ of $1 \%(\mathrm{wt} / \mathrm{vol}) \mathrm{KCl}$ and harvest the cells by centrifugation at $9000 \times g$ for $10 \mathrm{~min}$ at $4{ }^{\circ} \mathrm{C}$.

6. Resuspend with $1 \mathrm{~L}$ of lysis buffer and harvest the cells by centrifugation at $9000 \times g$ for $10 \mathrm{~min}$ at $4{ }^{\circ} \mathrm{C}$. The pellet weight should be $4.0 \mathrm{~g} / \mathrm{L}$ culture.

7. Resuspend with an equal amount of lysis buffer ( $1 \mathrm{~mL}$ buffer per $1 \mathrm{~g}$ cells $)$ and dispense the cells, through micropipettes, into liquid nitrogen to make frozen yeast droplets.

(1) PAUSE STEP Frozen cells can be stored at $-80^{\circ} \mathrm{C}$ for approximately one month.

\section{Cell lysis}

1. Disrupt the cells by mechanical grinding (see Appendix A).

2. Thaw the frozen powder of ground cells at $4{ }^{\circ} \mathrm{C}$ and centrifuge at $7500 \times g$ for $10 \mathrm{~min}$ at $4{ }^{\circ} \mathrm{C}$. Thereafter, transfer the supernatant to a clean tube (Sup 1, approximately $20 \mathrm{~mL}$ ).

3. Resuspend the resulting pellets with $30 \mathrm{~mL}$ of lysis buffer and centrifuge at $7500 \times$ $g$ for $10 \mathrm{~min}$ at $4{ }^{\circ} \mathrm{C}$. Thereafter, transfer the supernatant to a clean tube (Sup 2, approximately $30 \mathrm{~mL}$ ).

4. Combine Sup 1 and Sup 2 and transfer to a clean ultracentrifuge tube. Centrifuge at $150,000 \times g\left(450,000 \mathrm{rpm}\right.$, Type 70Ti, BECKMAN COULTER) for $3 \mathrm{~h}$ at $4{ }^{\circ} \mathrm{C}$. Thereafter, transfer the supernatants to a clean tube (S100, approximately $40 \mathrm{~mL}$ ).

NOTE: Take care to minimize contamination from either the lipid fraction at the very top or the cell debris at the bottom of the tube.

\section{Batch purification with $Q$ sepharose}

1. Incubate $\mathrm{S} 100$ and $15 \mathrm{~mL}$ of $\mathrm{Q}$ sepharose Fast Flow resin (Cytiva) pre-equilibrated with lysis buffer on a rotator at $4{ }^{\circ} \mathrm{C}$ for approximately $30 \mathrm{~min}$.

2. Sediment the resin by centrifugation at $500 \times g$ for $10 \mathrm{~min}$, then transfer the supernatant to a clean tube (flow-through fraction, approximately $40 \mathrm{~mL}$ ).

3. Add 1 column volume of lysis buffer to the resin and gently mix the slurry. Sediment the resin by centrifugation at $500 \times g$ for $10 \mathrm{~min}$, and then, transfer the supernatant to a clean tube (wash fraction, approximately $15 \mathrm{~mL}$ ).

4. Combine the flow-through and wash fractions (approximately $55 \mathrm{~mL}$ ).

(1) PAUSE STEP Freeze the sample with liquid nitrogen; then, it can be stored at $-80{ }^{\circ} \mathrm{C}$ for approximately 1 week.

\section{Purification by HiTrap SP column chromatography}

1. Load the sample $(55 \mathrm{~mL})$ at a flow rate of $1.0 \mathrm{~mL} / \mathrm{min}$ onto a HiTrap SP HP column (10 mL, Cytiva) that has been equilibrated with $5 \%$ (50 mM KCl) SP B buffer. 
2. After washing with 5 column volumes of $10 \%(100 \mathrm{mM} \mathrm{KCl}) \mathrm{SP} B$ buffer, elute with a linear gradient from 10 to $22.2 \%$ (100 to $220 \mathrm{mM} \mathrm{KCl}$ ) SP B buffer in 5 column volumes at a flow rate of $1.0 \mathrm{~mL} / \mathrm{min}$, collecting $2 \mathrm{~mL}$ fractions.

3. Elute with another 5 column volumes of $22.2 \%(220 \mathrm{mM} \mathrm{KCl}) \mathrm{SP} B$ buffer.

4. Analyze the fractions by $10 \%$ SDS-PAGE and pool fractions containing eEF1A. Typically, eEF1A is eluted at around 22\% SP B buffer, the volume of the pool is approximately $15 \mathrm{~mL}$.

\section{Purification by HiTrap Butyl column chromatography}

1. Add solid $\left(\mathrm{NH}_{4}\right)_{2} \mathrm{SO}_{4}$ slowly to the eEF1A pool, to a final concentration of $1.4 \mathrm{M}$ $\left(0.185 \mathrm{~g}\right.$ per $1 \mathrm{~mL}$ of eEF1A pool), mixing gently with a magnetic stirrer at $4{ }^{\circ} \mathrm{C}$.

2. Centrifuge the sample at $10,000 \times g$ for $10 \mathrm{~min}$ at $4{ }^{\circ} \mathrm{C}$. Thereafter, transfer the supernatant to a clean tube.

3. Load the sample at a flow rate of $1.0 \mathrm{~mL} / \mathrm{min}$ onto a HiTrap Butyl FF column $(10 \mathrm{~mL}$, Cytiva) which has been equilibrated with $0 \%\left(1.4 \mathrm{M}\left(\mathrm{NH}_{4}\right)_{2} \mathrm{SO}_{4}\right)$ Butyl B buffer.

4. After washing with 5 column volumes of $40 \%\left(840 \mathrm{mM}\left(\mathrm{NH}_{4}\right)_{2} \mathrm{SO}_{4}\right)$ Butyl B buffer, elute with a linear gradient from 40 to $100 \%$ (840 to $0 \mathrm{mM}\left(\mathrm{NH}_{4}\right)_{2} \mathrm{SO}_{4}$ ) Butyl B buffer in 15 column volumes at a flow rate of $1.0 \mathrm{~mL} / \mathrm{min}$, collecting $2 \mathrm{~mL}$ fractions.

5. Analyze the fractions by $10 \%$ SDS-PAGE and pool fractions that contain eEF1A. Typically, eEF1A is eluted at about $65 \%$ Butyl B buffer as a major peak, and the volume of the pool is approximately $30 \mathrm{~mL}$. Be careful not to collect the base of the peak, which contain impurities.

6. Dialyze the sample against $3 \mathrm{~L}$ of eEF1A stock buffer at $4{ }^{\circ} \mathrm{C}$ overnight with two changes of buffer; dialyze $2 \mathrm{~h}, 16 \mathrm{~h}$, and another $2 \mathrm{~h}$.

A CRITICAL STEP Residual ammonium sulfate in the purified eEF1A inhibits the translation.

7. Concentrate the purified protein to approximately $5 \mathrm{mg} / \mathrm{mL}$ using Amicon Ultra Centrifugal Filters (10 kDa cut-off) (MERCK).

8. Determine the concentration of the protein by the Bradford Assay or by using the adsorption coefficient of eEF1A (Figure S1).

9. The purified factors are aliquoted, fast-frozen in liquid nitrogen, and stored at $-80^{\circ} \mathrm{C}$. The yield is about $1 \mathrm{mg} / \mathrm{L}$ culture (Table S2).

\section{Notes}

1. To check the activity of the purified eEF1A, it is recommended to perform the translation reaction both in the presence and absence of eEF3, in order to analyze the eEF3 contamination levels. The purified eEF1A is contaminated with a small amount of eEF3 $(<1 \%)$, as estimated by western blotting analysis. Note here that a high concentration of eEF1A (10-20 times the ribosomal concentration) is utilized in a standard translation reaction condition. Therefore, only when extremely pure eEF1A is obtained, the omission of eEF3 reduces the translation efficiency by about half. Otherwise, there is little effect of eEF3 on the translation efficiency. In our hands, further purification by the gel filtration do not eliminate the contaminating eEF3 from the purified eEF1A.

\subsection{2. eEF2}

\section{Cell culture}

1. From a glycerol stock, streak a sample of TKY675/p416GPD-eEF2 yeast cells on a YPD plate and grow at $30^{\circ} \mathrm{C}$ for 2 days.

2. Collect the cells from the plate using a disposable loop, inoculate a $300 \mathrm{~mL}$ culture of YPD medium in a $500 \mathrm{~mL}$ flask with the cells, and then grow overnight (approximately $16 \mathrm{~h}$ ) at $30^{\circ} \mathrm{C}$ with vigorous shaking at $170 \mathrm{rpm}$. 
3. Inoculate twelve $900 \mathrm{~mL}$ culture of YPD medium in $2 \mathrm{~L}$ baffled flasks with $20 \mathrm{~mL}$ of the overnight culture per flask and grow at $30^{\circ} \mathrm{C}$ with vigorous shaking at $170 \mathrm{rpm}$, until the culture reaches an $\mathrm{OD}_{600}$ of 4.0 . This should take approximately $24 \mathrm{~h}$.

4. Harvest the cells by centrifugation at $9000 \times g$ for $10 \mathrm{~min}$ at $4{ }^{\circ} \mathrm{C}$.

5. Resuspend with $1 \mathrm{~L}$ of $1 \%(\mathrm{wt} / \mathrm{vol}) \mathrm{KCl}$ and harvest the cells by centrifugation at $9000 \times g$ for 10 min at $4{ }^{\circ} \mathrm{C}$.

6. Resuspend with $1 \mathrm{~L}$ of $1 \%(\mathrm{wt} / \mathrm{vol}) \mathrm{KCl}$ and harvest the cells by centrifugation at $9000 \times \mathrm{g}$ for $10 \mathrm{~min}$ at $4{ }^{\circ} \mathrm{C}$. The pellet weight should be $4.8 \mathrm{~g} / \mathrm{L}$ culture.

(1) PAUSE STEP Frozen cells can be stored at $-80^{\circ} \mathrm{C}$ for approximately one month.

\section{Cell lysis}

1. Add $2.5 \mathrm{~mL}$ of lysis buffer (Y-PER containing $10 \mu \mathrm{M}$ GDP, $0.2 \mathrm{mM}$ PMSF, and $5 \mathrm{mM}$ DTT) per $1 \mathrm{~g}$ of cells.

2. Stir until the mixture is homogenous, then stir for $20 \mathrm{~min}$ at room temperature.

3. Centrifuge the samples at $7500 \times g$ for $10 \mathrm{~min}$ at $4{ }^{\circ} \mathrm{C}$ and keep the supernatants.

\section{Purification with Ni-NTA agarose}

1. Incubate the lysate and $2 \mathrm{~mL}$ of Ni-NTA agarose resin (QIAGEN) equilibrated with Ni-NTA wash Buffer I on a rotator at $4{ }^{\circ} \mathrm{C}$ for approximately $30 \mathrm{~min}$.

2. Load the slurry into empty columns ( $1 \mathrm{~mL}$ resin/column, 2 columns). Collect the flow-through fractions in a clean tube.

3. Wash with 20 column volumes of Ni-NTA wash Buffer I ( $20 \mathrm{~mL}$ buffer/column). Collect the wash fractions into clean tubes.

4. Wash with 20 column volumes of Ni-NTA wash Buffer II ( $20 \mathrm{~mL}$ buffer/column). Collect the wash fractions into clean tubes.

5. Wash with 30 column volumes of Ni-NTA wash Buffer I ( $30 \mathrm{~mL}$ buffer/column). Collect the wash fractions into clean tubes.

6. Elute with 4 column volumes of Ni-NTA elution buffer ( $4 \mathrm{~mL}$ buffer/column). Collect the eluate fractions into clean tubes.

7. Analyze the fractions by $10 \%$ SDS-PAGE and pool fractions containing eEF2.

8. Dialyze the sample against $1 \mathrm{~L}$ of dialysis buffer at $4{ }^{\circ} \mathrm{C}$ overnight with a change of buffer after $1 \mathrm{~h}$.

9. OPTIONAL STEP: Clarify the sample by centrifugation at $10,000 \times g$ for $15 \mathrm{~min}$ at $4{ }^{\circ} \mathrm{C}$.

\section{Purification by HiTrap Q column chromatography}

1. Load the sample at a flow rate of $1.0 \mathrm{~mL} / \mathrm{min}$ onto a Hitrap Q HP column $(5 \mathrm{~mL}$, Cytiva) which has been equilibrated with $10 \%(100 \mathrm{mM} \mathrm{KCl}) \mathrm{B}$ buffer.

2. After washing with 5 column volumes of $10 \%(100 \mathrm{mM} \mathrm{KCl}) \mathrm{Q} B$ buffer, elute with a linear gradient from 10 to $25 \%$ ( 100 to $250 \mathrm{mM} \mathrm{KCl}$ ) Q B buffer in 15 column volumes at a flow rate of $2.0 \mathrm{~mL} / \mathrm{min}$, collecting $1.0 \mathrm{~mL}$ fractions.

3. Analyze the fractions by $10 \%$ SDS-PAGE and pool fractions that contain eEF2. Typically, eEF2 is eluted at about $23 \% \mathrm{~B}$ buffer as a major peak, and the volume of the pool is approximately $8 \mathrm{~mL}$. Be careful not to collect the base of the peak, which contains impurities.

4. Dialyze the sample against $1 \mathrm{~L}$ of eEF2 stock buffer at $4{ }^{\circ} \mathrm{C}$ overnight, with a change of buffer after $1 \mathrm{~h}$.

5. Concentrate the purified protein to approximately $5 \mathrm{mg} / \mathrm{mL}$ using Amicon Ultra Centrifugal Filters (10 kDa cut-off) (MERCK).

6. Determine the concentration of the protein by the Bradford Assay or by using the adsorption coefficient of eEF2 (Figure S1).

7. The purified factors are aliquoted, fast-frozen in liquid nitrogen, and stored at $-80^{\circ} \mathrm{C}$. The yield is about $40 \mu \mathrm{g} / \mathrm{L}$ culture (Table S2). 


\subsection{3. eEF3}

\section{Cell culture}

1. Freshly transform the plasmid pET29b-eEF3 (Table S2) into competent JM109(DE3)pRARE E. coli cells and grow overnight (approximately $12-16 \mathrm{~h}$ ) at $37^{\circ} \mathrm{C}$ on LB plates supplemented with $25 \mu \mathrm{g} / \mathrm{mL}$ kanamycin, $25 \mu \mathrm{g} / \mathrm{mL}$ chloramphenicol, and $1 \%(\mathrm{wt} / \mathrm{vol})$ glucose.

2. Pick a single colony and inoculate it into $50 \mathrm{~mL}$ of LB supplemented with $25 \mu \mathrm{g} / \mathrm{mL}$ kanamycin, $25 \mu \mathrm{g} / \mathrm{mL}$ chloramphenicol, and $1 \%$ (wt/vol) glucose, then grow overnight at $37^{\circ} \mathrm{C}$ with vigorous shaking at $170 \mathrm{rpm}$.

3. Inoculate four $1 \mathrm{~L}$ cultures of $2 \times$ YT supplemented with $25 \mu \mathrm{g} / \mathrm{mL}$ kanamycin, $25 \mu \mathrm{g} / \mathrm{mL}$ chloramphenicol, and $0.1 \%$ (wt/vol) glucose in $2 \mathrm{~L}$ baffled flasks with $10 \mathrm{~mL}$ of the overnight culture per flask and grow at $37^{\circ} \mathrm{C}$ with vigorous shaking at $170 \mathrm{rpm}$, until the culture reaches an $\mathrm{OD}_{600}$ of 0.5 . This should take approximately $2 \mathrm{~h}$.

4. Induce protein expression by adding $1 \mathrm{~mL}$ of $100 \mathrm{mM}$ IPTG (final $0.1 \mathrm{mM}$ ) per flask and grow at $37^{\circ} \mathrm{C}$ for $2 \mathrm{~h}$ with vigorous shaking at $170 \mathrm{rpm}$.

5. Harvest the cells by centrifugation at $9000 \times g$ for $10 \mathrm{~min}$ at $4{ }^{\circ} \mathrm{C}$.

6. Resuspend with $1 \mathrm{~L}$ of $1 \%(\mathrm{wt} / \mathrm{vol}) \mathrm{KCl}$ and harvest the cells by centrifugation at $9000 \times g$ for $10 \mathrm{~min}$ at $4{ }^{\circ} \mathrm{C}$.

7. Resuspend with $1 \mathrm{~L}$ of lysis buffer and harvest the cells by centrifugation at $9000 \times g$ for $10 \mathrm{~min}$ at $4{ }^{\circ} \mathrm{C}$. The pellet weight should be $2.0 \mathrm{~g} / \mathrm{L}$ culture.

(1) PAUSE STEP Frozen cells can be stored at $-80^{\circ} \mathrm{C}$ for approximately one month.

\section{Cell lysis}

1. Disrupt the cells by sonication (see Appendix A).

2. Centrifuge the disrupted cells at $10,000 \times g$ for $30 \mathrm{~min}$ at $4{ }^{\circ} \mathrm{C}$. Thereafter, transfer the supernatants to a clean tube.

3. Centrifuge the sample again at $10,000 \times g$ for $30 \mathrm{~min}$ at $4{ }^{\circ} \mathrm{C}$. Thereafter, transfer the supernatants to a clean tube.

\section{Purification with Ni-NTA agarose}

1. Incubate the lysate and $2 \mathrm{~mL}$ of Ni-NTA agarose resin (QIAGEN) equilibrated with lysis buffer on a rotator at $4{ }^{\circ} \mathrm{C}$ for approximately $30 \mathrm{~min}$.

2. Load the slurry into empty columns ( $1 \mathrm{~mL}$ resin/column, 2 columns). Collect the flow-through fractions in clean tubes.

3. Wash with 100 column volumes of Ni-NTA wash buffer (100 mL buffer/column). Collect the wash fractions and transfer to clean tubes.

4. Elute with 5 column volumes of Ni-NTA elution buffer ( $5 \mathrm{~mL}$ buffer/column). Collect the eluate fractions and transfer to clean tubes.

5. Analyze the fractions by $10 \%$ SDS-PAGE and pool fractions containing eEF3.

6. Dialyze the sample against $1 \mathrm{~L}$ of dialysis buffer at $4{ }^{\circ} \mathrm{C}$ overnight with a change of buffer after $1 \mathrm{~h}$.

7. OPTIONAL STEP: Clarify the sample by centrifugation at $10,000 \times g$ for $15 \mathrm{~min}$ at $4{ }^{\circ} \mathrm{C}$.

\section{Purification by HiTrap $Q$ column chromatography}

1. After diluting the sample 2-fold by adding an equal volume of $0 \%(0 \mathrm{mM} \mathrm{KCl}) \mathrm{Q} B$ buffer, load the sample at a flow rate of $0.5 \mathrm{~mL} / \mathrm{min}$ onto a HiTrap $\mathrm{Q}$ column $(5 \mathrm{~mL}$, Cytiva) which has been equilibrated with $5 \%(50 \mathrm{mM} \mathrm{KCl}) \mathrm{B}$ buffer.

2. After washing with 5 column volumes of $5 \%(50 \mathrm{mM} \mathrm{KCl}) \mathrm{Q} B$ buffer, elute with a linear gradient from 5 to $35 \%$ ( 50 to $350 \mathrm{mM} \mathrm{KCl}$ ) Q B buffer in 15 column volumes at a flow rate of $0.5 \mathrm{~mL} / \mathrm{min}$, collecting $1 \mathrm{~mL}$ fractions.

3. Analyze the fractions by $10 \%$ SDS-PAGE and pool fractions that contain eEF3. Typically, eEF3 is eluted at about $17 \%$ Q B buffer as a major peak, and the volume of 
the pool is approximately $7 \mathrm{~mL}$. Be careful not to collect the base of the peak, which contains impurities.

4. Dialyze the sample against $1 \mathrm{~L}$ of eEF3 stock buffer at $4{ }^{\circ} \mathrm{C}$ overnight, with a change of buffer after $1 \mathrm{~h}$.

5. Concentrate the purified protein to approximately $5 \mathrm{mg} / \mathrm{mL}$ using Amicon Ultra Centrifugal Filters (10 kDa cut-off) (MERCK).

6. Determine the concentration of the protein by the Bradford Assay or by using the adsorption coefficient of eEF3 (Figure S1).

7. The purified factors are aliquoted, fast-frozen in liquid nitrogen, and stored at $-80^{\circ} \mathrm{C}$. The yield is about $700 \mu \mathrm{g} / \mathrm{L}$ culture (Table S2).

\subsection{4. eRF1}

\section{Cell culture}

1. Freshly transform the plasmid pET21a-eRF1 (Table S2) into competent Rosetta(DE3)pLysS E. coli cells and grow overnight (approximately $12-16 \mathrm{~h}$ ) at $37{ }^{\circ} \mathrm{C}$ on LB plates supplemented with $100 \mu \mathrm{g} / \mathrm{mL}$ ampicillin, $25 \mu \mathrm{g} / \mathrm{mL}$ chloramphenicol, and $1 \%$ (wt/vol) glucose.

2. Pick a single colony and inoculate it into $30 \mathrm{~mL}$ of LB supplemented with $100 \mu \mathrm{g} / \mathrm{mL}$ ampicillin, $25 \mu \mathrm{g} / \mathrm{mL}$ chloramphenicol, and 1\% (wt/vol) glucose, and then, grow overnight at $37^{\circ} \mathrm{C}$ with vigorous shaking at $170 \mathrm{rpm}$.

3. Inoculate two $1 \mathrm{~L}$ cultures of $2 \times$ YT supplemented with $100 \mu \mathrm{g} / \mathrm{mL}$ ampicillin and $25 \mu \mathrm{g} / \mathrm{mL}$ chloramphenicol with $10 \mathrm{~mL}$ of the overnight culture per flask, and then, grow at $37{ }^{\circ} \mathrm{C}$ with vigorous shaking at $170 \mathrm{rpm}$ until the culture reaches an $\mathrm{OD}_{600}$ of 0.5 . This should take approximately $2 \mathrm{~h}$.

4. Induce protein expression by adding $1 \mathrm{~mL}$ of $100 \mathrm{mM}$ IPTG (final $0.1 \mathrm{mM}$ ) per flask and grow overnight (approximately $12-16 \mathrm{~h}$ ) at $18{ }^{\circ} \mathrm{C}$ with vigorous shaking at $170 \mathrm{rpm}$.

5. Harvest the cells by centrifugation at $9000 \times g$ for $10 \mathrm{~min}$ at $4{ }^{\circ} \mathrm{C}$.

6. Resuspend with $1 \mathrm{~L}$ of $1 \%(\mathrm{wt} / \mathrm{vol}) \mathrm{KCl}$ and harvest the cells by centrifugation at $9000 \times g$ for $10 \mathrm{~min}$ at $4{ }^{\circ} \mathrm{C}$.

7. Resuspend with $1 \mathrm{~L}$ of lysis buffer and harvest the cells by centrifugation at $9000 \times g$ for $10 \mathrm{~min}$ at $4^{\circ} \mathrm{C}$. The pellet weight should be $8.0 \mathrm{~g} / \mathrm{L}$ culture.

II PAUSE STEP Frozen cells can be stored at $-80{ }^{\circ} \mathrm{C}$ for approximately one month.

\section{Cell lysis}

1. Disrupt the cells by sonication (see Appendix A).

2. Centrifuge the disrupted cells at $10,000 \times g$ for $30 \mathrm{~min}$ at $4{ }^{\circ} \mathrm{C}$. Thereafter, transfer the supernatants to a clean tube.

3. Centrifuge the sample again at $10,000 \times g$ for $30 \mathrm{~min}$ at $4{ }^{\circ} \mathrm{C}$. Thereafter, transfer the supernatants to a clean tube.

\section{Purification with Ni-NTA agarose}

1. Incubate the lysate and $2 \mathrm{~mL}$ of Ni-NTA agarose resin (QIAGEN) equilibrated with lysis buffer on a rotator at $4{ }^{\circ} \mathrm{C}$ for approximately $30 \mathrm{~min}$.

2. Load the slurry into empty columns ( $1 \mathrm{~mL}$ resin/column, 2 columns). Collect the flow-through fractions in clean tubes.

3. Wash with 100 column volumes of Ni-NTA wash buffer (100 mL buffer/column). Collect the wash fractions in clean tubes.

4. Elute with 5 column volumes of Ni-NTA elution buffer ( $5 \mathrm{~mL}$ buffer/column). Collect the eluate fractions in clean tubes.

5. Analyze the fractions by $10 \%$ SDS-PAGE and pool fractions containing eRF1.

6. Dialyze the sample against $1 \mathrm{~L}$ of stock buffer at $4{ }^{\circ} \mathrm{C}$ overnight, with a change of buffer after $1 \mathrm{~h}$. 
7. OPTIONAL STEP: Clarify the sample by centrifugation at $10,000 \times g$ for $15 \mathrm{~min}$ at $4{ }^{\circ} \mathrm{C}$.

\section{Purification by HiTrap Q column chromatography}

1. Load the sample at a flow rate of $1.0 \mathrm{~mL} / \mathrm{min}$ onto a HiTrap Q HP column ( $20 \mathrm{~mL}$, Cytiva) that has been equilibrated with $10 \%(100 \mathrm{mM} \mathrm{KCl}) \mathrm{B}$ buffer.

2. Wash with 5 column volumes of $20 \%(200 \mathrm{mM} \mathrm{KCl}) \mathrm{Q}$ B buffer, then with another 5 column volumes of $30 \%(300 \mathrm{mM} \mathrm{KCl}) \mathrm{Q} B$ buffer, at a flow rate of $2.0 \mathrm{~mL} / \mathrm{min}$.

3. Elute with a linear gradient from 30 to $60 \%$ (300 to $600 \mathrm{mM} \mathrm{KCl}$ ) B buffer in 15 column volumes at a flow rate of $2.0 \mathrm{~mL} / \mathrm{min}$, collecting $4 \mathrm{~mL}$ fractions.

4. Analyze the fractions by $10 \%$ SDS-PAGE and pool fractions that contain eRF1. Typically, eRF1 is eluted at about $36 \%$ B buffer as a major peak, and the volume of the pool is approximately $20 \mathrm{~mL}$. Be careful not to collect the base of the peak, which contains impurities.

5. Dialyze the sample against $1 \mathrm{~L}$ of eRF1 stock buffer at $4{ }^{\circ} \mathrm{C}$ overnight, with a change of buffer after $1 \mathrm{~h}$.

6. Concentrate the purified protein to approximately $5 \mathrm{mg} / \mathrm{mL}$ using Amicon Ultra Centrifugal Filters (10 kDa cut-off) (MERCK).

7. Determine the concentration of the protein by the Bradford Assay or by using the adsorption coefficient of eRF1 (Figure S1).

8. The purified factors are aliquoted, fast-frozen in liquid nitrogen, and stored at $-80^{\circ} \mathrm{C}$. The yield is about $8.5 \mathrm{mg} / \mathrm{L}$ culture (Table S2).

\subsection{5. eRF3 $\Delta 165$}

\section{Cell culture}

1. Freshly transform the plasmid pET21a-eRF3 165 (Table S2) into competent BL21(DE3) E. coli cells and grow overnight (approximately $12-16 \mathrm{~h}$ ) at $37^{\circ} \mathrm{C}$ on LB plates supplemented with $100 \mu \mathrm{g} / \mathrm{mL}$ ampicillin and $1 \%$ (wt/vol) glucose.

2. Pick a single colony and inoculate it into $30 \mathrm{~mL}$ of LB supplemented with $100 \mu \mathrm{g} / \mathrm{mL}$ ampicillin, then grow overnight at $37^{\circ} \mathrm{C}$ with vigorous shaking at $170 \mathrm{rpm}$.

3. Inoculate two $1 \mathrm{~L}$ cultures of $2 \times \mathrm{YT}$ supplemented with $100 \mu \mathrm{g} / \mathrm{mL}$ ampicillin with $10 \mathrm{~mL}$ of the overnight culture per flask, then grow at $37^{\circ} \mathrm{C}$ with vigorous shaking at $170 \mathrm{rpm}$, until the culture reaches an $\mathrm{OD}_{600}$ of 0.5 . This should take approximately $2 \mathrm{~h}$.

4. Induce protein expression by adding $1 \mathrm{~mL}$ of $100 \mathrm{mM}$ IPTG (final $0.1 \mathrm{mM}$ ) per flask and grow overnight (approximately $12-16 \mathrm{~h}$ ) at $18{ }^{\circ} \mathrm{C}$ with vigorous shaking at $170 \mathrm{rpm}$.

5. Harvest the cells by centrifugation at $9000 \times g$ for 10 min at $4{ }^{\circ} \mathrm{C}$.

6. Resuspend with $1 \mathrm{~L}$ of $1 \%(\mathrm{wt} / \mathrm{vol}) \mathrm{KCl}$ and harvest the cells by centrifugation at $9000 \times g$ for $10 \mathrm{~min}$ at $4{ }^{\circ} \mathrm{C}$.

7. Resuspend with $1 \mathrm{~L}$ of lysis buffer and harvest the cells by centrifugation at $9000 \times g$ for $10 \mathrm{~min}$ at $4{ }^{\circ} \mathrm{C}$. The pellet weight should be $7.8 \mathrm{~g} / \mathrm{L}$ culture.

(1) PAUSE STEP Frozen cells can be stored at $-80^{\circ} \mathrm{C}$ for approximately one month.

\section{Cell lysis}

1. Disrupt the cells by sonication (see Appendix A).

2. Centrifuge the disrupted cells at $10,000 \times g$ for $30 \mathrm{~min}$ at $4{ }^{\circ} \mathrm{C}$. Thereafter, transfer the supernatants to a clean tube.

3. Centrifuge the sample again at $10,000 \times g$ for $30 \mathrm{~min}$ at $4{ }^{\circ} \mathrm{C}$. Thereafter, transfer the supernatants to a clean tube.

\section{Purification with Ni-NTA agarose}

1. Incubate the lysate and $4 \mathrm{~mL}$ of Ni-NTA agarose resin (QIAGEN) equilibrated with lysis buffer on a rotator at $4{ }^{\circ} \mathrm{C}$ for approximately $30 \mathrm{~min}$. 
2. Load the slurry into empty columns ( $1 \mathrm{~mL}$ resin/column, 4 columns). Collect the flow-through fractions in clean tubes.

3. Wash with 100 column volumes of Ni-NTA wash buffer (100 mL buffer/column). Collect the wash fractions in clean tubes.

4. Elute with 5 column volumes of Ni-NTA elution buffer ( $5 \mathrm{~mL}$ buffer/column). Collect the eluate fractions in clean tubes.

5. Analyze the fractions by $10 \%$ SDS-PAGE and pool fractions containing eRF3 $\Delta 165$.

6. Dialyze the sample against $1 \mathrm{~L}$ of stock buffer at $4{ }^{\circ} \mathrm{C}$ overnight, with a change of buffer after $1 \mathrm{~h}$.

7. OPTIONAL STEP: Clarify the sample by centrifugation at $10,000 \times g$ for $15 \mathrm{~min}$ at $4{ }^{\circ} \mathrm{C}$.

\section{Purification by HiTrap Q column chromatography}

1. Load the sample at a flow rate of $1.0 \mathrm{~mL} / \mathrm{min}$ onto a HiTrap Q HP column $(20 \mathrm{~mL}$, Cytiva) which has been equilibrated with $10 \%(100 \mathrm{mM} \mathrm{KCl}) \mathrm{Q} B$ buffer.

2. After washing with 5 column volumes of $10 \%(100 \mathrm{mM} \mathrm{KCl}) \mathrm{Q} B$ buffer, elute with a linear gradient from 10 to $30 \%$ ( 100 to $300 \mathrm{mM} \mathrm{KCl}$ ) Q B buffer in 15 column volumes at a flow rate of $2.0 \mathrm{~mL} / \mathrm{min}$, collecting $4 \mathrm{~mL}$ fractions.

3. Analyze the fractions by $10 \%$ SDS-PAGE and pool fractions that contain eRF3 $\Delta 165$. Typically, eRF3 $\Delta 165$ is eluted at about $17 \%$ B buffer as a major peak, and the volume of the pool is approximately $35 \mathrm{~mL}$. Be careful not to collect the base of the peak, which contains impurities.

4. Dialyze the sample against $2 \mathrm{~L}$ of eRF3 $\Delta 165$ stock buffer at $4{ }^{\circ} \mathrm{C}$ overnight, with a change of buffer after $1 \mathrm{~h}$.

5. Concentrate the purified protein to approximately $5 \mathrm{mg} / \mathrm{mL}$ using Amicon Ultra Centrifugal Filters (10 kDa cut-off) (MERCK).

6. Determine the concentration of the protein by the Bradford Assay or by using the adsorption coefficient of eRF3 (Figure S1).

7. The purified factors are aliquoted, fast-frozen in liquid nitrogen, and stored at $-80^{\circ} \mathrm{C}$. The yield is about $24 \mathrm{mg} / \mathrm{L}$ culture (Table S2).

\section{Notes}

1. eRF3 $\Delta 165$ is the more stable version of the full-length eRF3 with the deletion of the $\mathrm{N}$-terminal amino acids not involved in function.

\subsubsection{Dom34}

\section{Cell culture}

1. Freshly transform the plasmid pET29b-Dom34 (Table S2) into competent Rosetta(DE3)pLysS E. coli cells and grow overnight (approximately $12-16 \mathrm{~h}$ ) at $37^{\circ} \mathrm{C}$ on LB plates supplemented with $25 \mu \mathrm{g} / \mathrm{mL}$ kanamycin, $25 \mu \mathrm{g} / \mathrm{mL}$ chloramphenicol, and $1 \%$ (wt/vol) glucose.

2. Pick a single colony and inoculate it into $30 \mathrm{~mL}$ of LB supplemented with $25 \mu \mathrm{g} / \mathrm{mL}$ kanamycin, $25 \mu \mathrm{g} / \mathrm{mL}$ chloramphenicol, and $1 \%$ (wt/vol) glucose, then grow overnight at $37^{\circ} \mathrm{C}$ with vigorous shaking at $170 \mathrm{rpm}$.

3. Inoculate two $1 \mathrm{~L}$ cultures of $2 \times \mathrm{YT}$ supplemented with $25 \mu \mathrm{g} / \mathrm{mL}$ kanamycin and $25 \mu \mathrm{g} / \mathrm{mL}$ chloramphenicol with $10 \mathrm{~mL}$ of the overnight culture per flask, and then, grow at $37^{\circ} \mathrm{C}$ with vigorous shaking at $170 \mathrm{rpm}$, until the culture reaches an $\mathrm{OD}_{600}$ of 0.5 . This should take approximately $2 \mathrm{~h}$.

4. Induce protein expression by adding $1 \mathrm{~mL}$ of $100 \mathrm{mM}$ IPTG (final $0.1 \mathrm{mM}$ ) per flask and grow overnight (approximately $12-16 \mathrm{~h}$ ) at $18{ }^{\circ} \mathrm{C}$ with vigorous shaking at $170 \mathrm{rpm}$.

5. Harvest the cells by centrifugation at $9000 \times g$ for 10 min at $4{ }^{\circ} \mathrm{C}$.

6. Resuspend with $1 \mathrm{~L}$ of $1 \%(\mathrm{wt} / \mathrm{vol}) \mathrm{KCl}$ and harvest the cells by centrifugation at $9000 \times g$ for $10 \mathrm{~min}$ at $4{ }^{\circ} \mathrm{C}$. 
7. Resuspend with $1 \mathrm{~L}$ of lysis buffer and harvest the cells by centrifugation at $9000 \times g$ for $10 \mathrm{~min}$ at $4{ }^{\circ} \mathrm{C}$. The pellet weight should be $9.6 \mathrm{~g} / \mathrm{L}$ culture.

(I) PAUSE STEP Frozen cells can be stored at $-80^{\circ} \mathrm{C}$ for approximately one month. Cell lysis

1. Disrupt the cells by sonication (see Appendix A).

2. Centrifuge the disrupted cells at $10,000 \times g$ for $30 \mathrm{~min}$ at $4{ }^{\circ} \mathrm{C}$. Thereafter, transfer the supernatants to a clean tube.

3. Centrifuge the sample again at $10,000 \times g$ for $30 \mathrm{~min}$ at $4{ }^{\circ} \mathrm{C}$. Thereafter, transfer the supernatants to a clean tube.

\section{Purification with Ni-NTA agarose}

1. Incubate the lysate and $4 \mathrm{~mL}$ of Ni-NTA agarose resin (QIAGEN) equilibrated with lysis buffer on a rotator at $4{ }^{\circ} \mathrm{C}$ for approximately $30 \mathrm{~min}$.

2. Load the slurry into empty columns ( $1 \mathrm{~mL}$ resin/column, 4 columns). Collect the flow-through fractions in clean tubes.

3. Wash with 100 column volumes of Ni-NTA wash buffer ( $100 \mathrm{~mL}$ buffer/column). Collect the wash fractions in clean tubes.

4. Elute with 5 column volumes of Ni-NTA elution buffer ( $5 \mathrm{~mL}$ buffer/column). Collect the eluate fractions in clean tubes.

5. Analyze the fractions by $10 \%$ SDS-PAGE and pool fractions containing Dom 34 .

6. Dialyze the sample against $1 \mathrm{~L}$ of stock buffer at $4{ }^{\circ} \mathrm{C}$ overnight, with a change of buffer after $1 \mathrm{~h}$.

7. OPTIONAL STEP: Clarify the sample by centrifugation at $10,000 \times g$ for $15 \mathrm{~min}$ at $4{ }^{\circ} \mathrm{C}$.

\section{Purification by HiPrep $Q$ column chromatography}

1. After diluting the sample 2 -fold by adding an equal volume of $0 \%(0 \mathrm{mM} \mathrm{KCl}) \mathrm{Q} B$ buffer, load the sample at a flow rate of $2.0 \mathrm{~mL} / \mathrm{min}$ onto a HiPrep Q HP column (20 mL, Cytiva) which has been equilibrated with $10 \%$ (100 mM KCl) Q B buffer.

2. After washing with 5 column volumes of $10 \%(100 \mathrm{mM} \mathrm{KCl}) \mathrm{Q} B$ buffer, elute with a linear gradient from 10 to $50 \%$ (100 to $500 \mathrm{mM} \mathrm{KCl}) \mathrm{Q} B$ buffer in 15 column volumes at a flow rate of $2.0 \mathrm{~mL} / \mathrm{min}$, collecting $4 \mathrm{~mL}$ fractions.

3. Analyze the fractions by $10 \%$ SDS-PAGE and pool fractions that contain Dom 34 . Typically, Dom 34 is eluted as a major peak at about $24 \%$ Q B buffer, with the former half of the peak containing impurities of about $38 \mathrm{kDa}$ and the latter half of the peak containing impurities of about $40 \mathrm{kDa}$. Pool the latter half of the peak, which is approximately $50 \mathrm{~mL}$.

4. Dialyze the sample against $2 \mathrm{~L}$ of Dom 34 stock buffer at $4{ }^{\circ} \mathrm{C}$ overnight with a change of buffer after $1 \mathrm{~h}$.

\section{Purification by HiLoad 16/600 Superdex 200 pg column chromatography}

1. Concentrate the sample volume to $\leq 5 \mathrm{~mL}$ using Amicon Ultra Centrifugal Filters (10 kDa cut-off) (MERCK).

2. Load the sample at a flow rate of $0.5 \mathrm{~mL} / \mathrm{min}$ onto a HiLoad 16/600 Superdex $200 \mathrm{pg}$ column (Cytiva) which has been equilibrated with Dom34 stock buffer, collecting $1.2 \mathrm{~mL}$ fractions.

3. Analyze the fractions by $10 \%$ SDS-PAGE and pool fractions that contain Dom 34 . Typically, Dom34 is eluted at around $70 \mathrm{~mL}$ as a major peak, and the volume of the pool is approximately $7 \mathrm{~mL}$. Be careful not to collect the base of the peak, which contains impurities.

4. Concentrate the purified protein to approximately $5 \mathrm{mg} / \mathrm{mL}$ using Amicon Ultra Centrifugal Filters (10 kDa cut-off) (MERCK).

5. Determine the concentration of the protein by the Bradford Assay or by using the adsorption coefficient of Dom34 (Figure S1). 
6. The purified factors are aliquoted, fast-frozen in liquid nitrogen, and stored at $-80{ }^{\circ} \mathrm{C}$. The yield is about $2.2 \mathrm{mg} / \mathrm{L}$ culture (Table S2).

\subsubsection{Hbs1}

\section{Cell culture}

1. Freshly transform the plasmid pETDuet-1-Hbs1 (Table S2) into competent BL21(DE3) E. coli cells, and then, grow overnight (approximately $12-16 \mathrm{~h}$ ) at $37^{\circ} \mathrm{C}$ on LB plates supplemented with $100 \mu \mathrm{g} / \mathrm{mL}$ ampicillin and $1 \%$ (wt/vol) glucose.

2. Pick a single colony and inoculate it into $30 \mathrm{~mL}$ of LB supplemented with $100 \mu \mathrm{g} / \mathrm{mL}$ ampicillin, and then, grow overnight at $37{ }^{\circ} \mathrm{C}$ with vigorous shaking at $170 \mathrm{rpm}$.

3. Inoculate two $1 \mathrm{~L}$ cultures of $2 \times$ YT supplemented with $100 \mu \mathrm{g} / \mathrm{mL}$ ampicillin with $10 \mathrm{~mL}$ of the overnight culture per flask, and then grow at $37^{\circ} \mathrm{C}$ with vigorous shaking at $170 \mathrm{rpm}$, until the culture reaches an $\mathrm{OD}_{600}$ of 0.5 . This should take approximately $2 \mathrm{~h}$.

4. Induce protein expression by adding $1 \mathrm{~mL}$ of $100 \mathrm{mM}$ IPTG (final $0.1 \mathrm{mM}$ ) per flask, and then, grow overnight (approximately $12-16 \mathrm{~h}$ ) at $18^{\circ} \mathrm{C}$ with vigorous shaking at $170 \mathrm{rpm}$.

5. Harvest the cells by centrifugation at $9000 \times g$ for $10 \mathrm{~min}$ at $4{ }^{\circ} \mathrm{C}$.

6. Resuspend with $1 \mathrm{~L}$ of $1 \%(\mathrm{wt} / \mathrm{vol}) \mathrm{KCl}$ and harvest the cells by centrifugation at $9000 \times g$ for $10 \mathrm{~min}$ at $4{ }^{\circ} \mathrm{C}$.

7. Resuspend with $1 \mathrm{~L}$ of lysis buffer and harvest the cells by centrifugation at $9000 \times g$ for $10 \mathrm{~min}$ at $4{ }^{\circ} \mathrm{C}$. The pellet weight should be $7.8 \mathrm{~g} / \mathrm{L}$ culture.

(1) PAUSE STEP Frozen cells can be stored at $-80^{\circ} \mathrm{C}$ for approximately one month.

\section{Cell lysis}

1. Disrupt the cells by sonication (see Appendix A).

2. Centrifuge the disrupted cells at $10,000 \times g$ for $30 \mathrm{~min}$ at $4{ }^{\circ} \mathrm{C}$. Thereafter, transfer the supernatants to a clean tube.

3. Centrifuge the sample again at $10,000 \times g$ for $30 \mathrm{~min}$ at $4{ }^{\circ} \mathrm{C}$. Thereafter, transfer the supernatants to a clean tube.

\section{Purification with Ni-NTA agarose}

1. Incubate the lysate and $2 \mathrm{~mL}$ of Ni-NTA agarose resin (QIAGEN) equilibrated with lysis buffer on a rotator at $4{ }^{\circ} \mathrm{C}$ for approximately $30 \mathrm{~min}$.

2. Load the slurry into empty columns ( $1 \mathrm{~mL}$ resin/column, 2 columns). Collect the flow-through fractions in clean tubes.

3. Wash with 100 column volumes of Ni-NTA wash buffer (100 mL buffer/column). Collect the wash fractions in clean tubes.

4. Elute with 5 column volumes of Ni-NTA elution buffer ( $5 \mathrm{~mL}$ buffer/column). Collect the eluate fractions in clean tubes.

5. Analyze the fractions by $10 \%$ SDS-PAGE and pool fractions containing Hbs1.

6. Dialyze the sample against $1 \mathrm{~L}$ of stock buffer at $4{ }^{\circ} \mathrm{C}$ overnight, with a change of buffer after $1 \mathrm{~h}$.

7. OPTIONAL STEP: Clarify the sample by centrifugation at $10,000 \times g$ for $15 \mathrm{~min}$ at $4{ }^{\circ} \mathrm{C}$.

\section{Purification by HiTrap Q column chromatography}

1. Load the sample at a flow rate of $1 \mathrm{~mL} / \mathrm{min}$ onto a HiTrap $\mathrm{Q}$ column $(10 \mathrm{~mL}$, Cytiva) which has been equilibrated with $10 \%(100 \mathrm{mM} \mathrm{KCl}) \mathrm{Q} B$ buffer.

2. After washing with 3 column volumes of $10 \%(100 \mathrm{mM} \mathrm{KCl}) \mathrm{Q} B$ buffer and then with another 3 column volumes of $25 \%(250 \mathrm{mM} \mathrm{KCl}) \mathrm{Q}$ B buffer, elute with a linear gradient from 25 to $60 \%$ ( 250 to $600 \mathrm{mM} \mathrm{KCl}$ ) Q B buffer in 15 column volumes at a flow rate of $2 \mathrm{~mL} / \mathrm{min}$, collecting $2 \mathrm{~mL}$ fractions.

3. Analyze the fractions by $10 \%$ SDS-PAGE and pool fractions that contain Hbs1. Typically, $\mathrm{Hbs} 1$ is eluted at about $37 \% \mathrm{Q} B$ buffer as a major peak, and the volume of the 
pool is approximately $10 \mathrm{~mL}$. Be careful not to collect the base of the peak, which contains impurities.

4. Dialyze the sample against $1 \mathrm{~L}$ of $\mathrm{Hbs} 1$ stock buffer at $4{ }^{\circ} \mathrm{C}$ overnight, with a change of buffer after $1 \mathrm{~h}$.

5. Concentrate the purified protein to approximately $5 \mathrm{mg} / \mathrm{mL}$ using Amicon Ultra Centrifugal Filters (10 kDa cut-off) (MERCK).

6. Determine the concentration of the protein by the Bradford Assay or by using the adsorption coefficient of Hbs1 (Figure S1).

7. The purified factors are aliquoted, fast-frozen in liquid nitrogen, and stored at $-80^{\circ} \mathrm{C}$. The yield is about $1.6 \mathrm{mg} / \mathrm{L}$ culture (Table S2).

3.1.8. Rli1

\section{Cell culture}

1. From a glycerol stock, streak a sample of INVSc1/pYES2-Rli1 yeast cells on a SC-Ura plate containing $1 \%(\mathrm{wt} / \mathrm{vol})$ raffinose, and then, grow at $30{ }^{\circ} \mathrm{C}$ for 2 days.

2. Collect the cells from the plate using a disposable loop, inoculate two $400 \mathrm{~mL}$ cultures of SC-Ura medium containing $1 \%$ (wt/vol) raffinose in $500 \mathrm{~mL}$ flasks with the cells, and then grow at $30^{\circ} \mathrm{C}$ for 2 days with vigorous shaking at $170 \mathrm{rpm}$.

3. Inoculate twelve $720 \mathrm{~mL}$ cultures of SC-Ura medium containing $1 \%(\mathrm{wt} / \mathrm{vol})$ raffinose in $2 \mathrm{~L}$ baffled flasks with $60 \mathrm{~mL}$ of the overnight culture per flask, and then, grow at $30{ }^{\circ} \mathrm{C}$ for $2 \mathrm{~h}$ with vigorous shaking at $170 \mathrm{rpm}$.

4. Induce protein expression by adding $80 \mathrm{~mL}$ of $20 \%$ (wt/vol) galactose (final concentration $2 \%(\mathrm{wt} / \mathrm{vol}))$ per flask, and then, grow at $30{ }^{\circ} \mathrm{C}$ with vigorous shaking at $170 \mathrm{rpm}$, until the culture reaches an $\mathrm{OD}_{600}$ of 7.0. This should take approximately $20 \mathrm{~h}$.

5. Harvest the cells by centrifugation at $9000 \times g$ for $10 \mathrm{~min}$ at $4{ }^{\circ} \mathrm{C}$.

6. Resuspend with $1 \mathrm{~L}$ of $1 \%(\mathrm{wt} / \mathrm{vol}) \mathrm{KCl}$ and harvest the cells by centrifugation at $9000 \times g$ for $10 \mathrm{~min}$ at $4{ }^{\circ} \mathrm{C}$.

7. Resuspend with $1 \mathrm{~L}$ of lysis buffer and harvest the cells by centrifugation at $9000 \times g$ for $10 \mathrm{~min}$ at $4{ }^{\circ} \mathrm{C}$. The pellet weight should be $4.0 \mathrm{~g} / \mathrm{L}$ culture.

8. Resuspend with an equal amount of lysis buffer ( $1 \mathrm{~mL}$ buffer per $1 \mathrm{~g}$ cells) and dispense the cells through micropipettes into liquid nitrogen, to form frozen yeast droplets.

(1) PAUSE STEP Frozen cells can be stored at $-80^{\circ} \mathrm{C}$ for approximately one month. Cell lysis

1. Disrupt the cells by mechanical grinding (see Appendix A).

2. Add $25 \mathrm{~mL}$ of lysis buffer to the frozen powder of ground cells and thaw the sample at $4{ }^{\circ} \mathrm{C}$. Thereafter, centrifuge at $7500 \times g$ for $10 \mathrm{~min}$ at $4{ }^{\circ} \mathrm{C}$, and then, transfer the supernatants to a clean tube (Sup 1, approximately $80 \mathrm{~mL}$ ).

3. Resuspend the resulting pellets with $75 \mathrm{~mL}$ of lysis buffer.

4. Disrupt the suspension of cell debris again using a sonicator (Branson) (pulse on, $2 \mathrm{~s}$; pulse off, $8 \mathrm{~s}$; power, 80 watts; time, $5 \mathrm{~min}$ ).

5. Centrifuge the sample at $7500 \times g$ for $10 \mathrm{~min}$ at $4{ }^{\circ} \mathrm{C}$. Thereafter, transfer the supernatants to a clean tube (Sup 2, approximately $50 \mathrm{~mL}$ ).

6. Combine Sup 1 and Sup 2 and transfer to a clean ultracentrifuge tube. Centrifuge at $17,000 \times g\left(15,000 \mathrm{rpm}\right.$, Type $45 \mathrm{Ti}$, BECKMAN COULTER) for $30 \mathrm{~min}$ at $4{ }^{\circ} \mathrm{C}$. Thereafter, transfer the supernatants to a clean tube (approximately 110-120 mL).

NOTE: Take care to minimize contamination from either the lipid fraction at the very top or the cell debris at the bottom of the tube.

\section{Purification with Ni-NTA agarose}

1. Incubate the lysate and $2 \mathrm{~mL}$ of Ni-NTA agarose resin (QIAGEN) equilibrated with lysis buffer on a rotator at $4{ }^{\circ} \mathrm{C}$ for approximately $30 \mathrm{~min}$. 
2. Load the slurry into empty columns ( $1 \mathrm{~mL}$ resin/column, 2 columns). Collect the flow-through fractions in clean tubes.

3. Wash with 100 column volumes of Ni-NTA wash buffer (100 mL buffer/column). Collect the wash fractions in clean tubes.

4. Wash with 50 column volumes of Ni-NTA wash buffer containing $1 \%$ Tween 20 (50 $\mathrm{mL}$ buffer/column). Collect the wash fractions in clean tubes.

5. Elute with 5 column volumes of Ni-NTA elution buffer ( $5 \mathrm{~mL}$ buffer/column). Collect the eluate fractions in clean tubes.

6. Analyze the fractions by $10 \%$ SDS-PAGE and pool fractions containing Rli1.

7. Dialyze the sample against $1 \mathrm{~L}$ of HiTrap SP A buffer containing $0.1 \mathrm{mM}$ PMSF at $4{ }^{\circ} \mathrm{C}$ overnight, with a change of buffer after $1 \mathrm{~h}$.

8. OPTIONAL STEP: Clarify the sample by centrifugation at $10,000 \times g$ for $15 \mathrm{~min}$ at $4{ }^{\circ} \mathrm{C}$.

\section{Purification by $Q$ sepharose column chromatography}

1. Incubate the sample and $3 \mathrm{~mL}$ of $\mathrm{Q}$ sepharose Fast Flow resin (Cytiva) equilibrated with HiTrap SP A buffer on a rotator at $4{ }^{\circ} \mathrm{C}$ for approximately $30 \mathrm{~min}$.

2. Sediment the resin by centrifugation at $500 \times \mathrm{g}$ for $10 \mathrm{~min}$, and then, transfer the supernatant to a clean tube (flow-through Fraction 1, approximately $45 \mathrm{~mL}$ ).

3. Add 1 column volume of HiTrap SP A buffer to the resin and gently mix the slurry. Thereafter, sediment the resin by centrifugation at $500 \times g$ for $10 \mathrm{~min}$, and then, transfer the supernatant to a clean tube (flow-through Fraction 2, approximately $3 \mathrm{~mL}$ ).

4. Combine the flow-through Fractions 1 and 2 in a clean tube (approximately $50 \mathrm{~mL}$ ).

\section{Purification by HiTrap SP column chromatography}

1. Load the sample at a flow rate of $1.0 \mathrm{~mL} / \mathrm{min}$ onto a HiTrap SP HP column $(5 \mathrm{~mL}$, Cytiva) which has been equilibrated with $0 \%(100 \mathrm{mM} \mathrm{KCl})$ SP B buffer.

2. After washing with 5 column volumes of $0 \%(100 \mathrm{mM} \mathrm{KCl}) \mathrm{SP} \mathrm{B}$ buffer, elute with a linear gradient from 0 to $40 \%$ ( 100 to $460 \mathrm{mM} \mathrm{KCl}$ ) SP B buffer in 10 column volumes at a flow rate of $2.0 \mathrm{~mL} / \mathrm{min}$, collecting $1 \mathrm{~mL}$ fractions.

3. Analyze the fractions by $10 \%$ SDS-PAGE and pool fractions that contain Rli1. Typically, Rli1 is eluted at about $22 \%$ SP B buffer as a major peak, and the volume of the pool is approximately $8 \mathrm{~mL}$. Be careful not to collect the base of the peak, which contains impurities.

4. Dialyze the sample against $1 \mathrm{~L}$ of Rli1 stock buffer at $4{ }^{\circ} \mathrm{C}$ overnight, with a change of buffer after $1 \mathrm{~h}$.

5. Concentrate the purified protein to approximately $5 \mathrm{mg} / \mathrm{mL}$ using Amicon Ultra Centrifugal Filters (10 kDa cut-off) (MERCK).

6. Determine the concentration of the protein by the Bradford Assay or by using the adsorption coefficient of Rli1 (Figure S1).

7. The purified factors are aliquoted, fast-frozen in liquid nitrogen, and stored at $-80{ }^{\circ} \mathrm{C}$. The yield is about $35 \mu \mathrm{g} / \mathrm{L}$ culture (Table S2).

\subsubsection{Ribosomes}

\section{Cell culture}

1. From a glycerol stock, streak a sample of W303 yeast cells on a YPD plate and grow at $30{ }^{\circ} \mathrm{C}$ for 1 day.

2. Collect the cells from the plate using a disposable loop, inoculate a $300 \mathrm{~mL}$ culture of YPD medium in a $500 \mathrm{~mL}$ flask with the cells, and then, grow overnight (approximately $16 \mathrm{~h}$ ) at $30^{\circ} \mathrm{C}$ with vigorous shaking at $170 \mathrm{rpm}$.

3. Inoculate twelve $900 \mathrm{~mL}$ cultures of YPD medium in $2 \mathrm{~L}$ baffled flasks with $20 \mathrm{~mL}$ of the overnight culture per flask, and then, grow at $30{ }^{\circ} \mathrm{C}$ with vigorous shaking at $170 \mathrm{rpm}$, until the culture reaches an $\mathrm{OD}_{600}$ of $1.0 \pm 0.1$. This should take approximately $4-6 \mathrm{~h}$.

4. Harvest the cells by centrifugation at $9000 \times g$ for 10 min at $4{ }^{\circ} \mathrm{C}$. 
5. Resuspend with $1 \mathrm{~L}$ of $1 \%(\mathrm{wt} / \mathrm{vol}) \mathrm{KCl}$ and harvest the cells by centrifugation at $9000 \times g$ for $10 \mathrm{~min}$ at $4{ }^{\circ} \mathrm{C}$.

6. Resuspend with $1 \mathrm{~L}$ of lysis buffer and harvest the cells by centrifugation at $9000 \times g$ for $10 \mathrm{~min}$ at $4{ }^{\circ} \mathrm{C}$. The pellet weight should be $1.0 \mathrm{~g} / \mathrm{L}$ culture.

7. Resuspend with an equal amount of lysis buffer ( $1 \mathrm{~mL}$ buffer per $1 \mathrm{~g}$ cells) and dispense the cells through micropipettes into liquid nitrogen to form frozen yeast droplets.

(1) PAUSE STEP Frozen cells can be stored at $-80^{\circ} \mathrm{C}$ for approximately one month.

\section{Cell lysis}

1. Disrupt the cells by mechanical grinding (see Appendix A).

2. Add $15 \mathrm{~mL}$ of lysis buffer to the frozen powder of ground cells and thaw the sample at $4{ }^{\circ} \mathrm{C}$. Thereafter, centrifuge at $1000 \times g$ for $10 \mathrm{~min}$ at $4{ }^{\circ} \mathrm{C}$, and then, transfer the supernatants to a clean tube (Sup 1).

3. Resuspend the resulting pellets with $22.5 \mathrm{~mL}$ of lysis buffer and centrifuge at $1000 \times g$ for $10 \mathrm{~min}$ at $4{ }^{\circ} \mathrm{C}$. Thereafter, transfer the supernatants to a clean tube (Sup 2).

4. Combine Sup 1 and Sup 2 (approximately $50 \mathrm{~mL}$ ), add $1.25 \mu \mathrm{L}$ of TURBO DNase (Thermo Fisher Scientific) per $10 \mathrm{~mL}$ of lysate, and then, divide into two clean ultracentrifuge tubes.

5. Centrifuge at $30,000 \times g(21,000 \mathrm{rpm}$, Type 70Ti, BECKMAN COULTER) for $30 \mathrm{~min}$ at $4{ }^{\circ} \mathrm{C}$. Thereafter, transfer the supernatants to a clean tube (S30, approximately $40 \mathrm{~mL}$ ).

NOTE: Take care to minimize contamination from either the lipid fraction at the very top or the cell debris at the bottom of the tube.

\section{Purification of crude ribosomes}

1. Dilute approximately $40 \mathrm{~mL}$ of $\mathrm{S} 30$ with lysis buffer up to $90 \mathrm{~mL}$ and divide into four 70Ti polycarbonate ultracentrifuge tubes (BECKMAN COULTER).

2. Place $2.5 \mathrm{~mL}$ of sucrose cushion Buffer I at the very bottom of the 70Ti tubes using a syringe.

3. Centrifuge at $100,000 \times g(60,000 \mathrm{rpm}$, Type $70 \mathrm{Ti}$, BECKMAN COULTER) for $2 \mathrm{~h}$ at $4{ }^{\circ} \mathrm{C}$. Then, aspirate off the supernatants.

4. Add $500 \mu \mathrm{L}$ of puromycin treatment buffer per ultracentrifuge tube, dissolve the pellet with gentle shaking for $20 \mathrm{~min}$ at $4{ }^{\circ} \mathrm{C}$, and then transfer to a clean tube.

5. Repeat Step 4 three times ( $1 \mathrm{~h}$ in total).

6. Centrifuge at $13,000 \times g$ for $5 \mathrm{~min}$ at $4{ }^{\circ} \mathrm{C}$. Thereafter, transfer the supernatant to a clean tube (crude ribosomes, approximately $6 \mathrm{~mL}$ ).

7. Quantify the crude ribosomes using a spectrometer. The yield is approximately 1500 $\mathrm{A}_{260}$ units.

(1) PAUSE STEP Freeze the sample with liquid nitrogen, they can be stored at $-80{ }^{\circ} \mathrm{C}$ for approximately 1 day.

\section{Purification of 80 S ribosomes by HiTrap Butyl column chromatography}

1. Add puromycin treatment buffer, such that the sample volume becomes $6 \mathrm{~mL}$. Thereafter, add $300 \mu \mathrm{L}$ of $10 \mathrm{mM}$ puromycin (final $0.5 \mathrm{mM}$ ) and $60 \mu \mathrm{L}$ of $100 \mathrm{mM}$ GTP (final $1 \mathrm{mM}$ ) to the $6 \mathrm{~mL}$ of crude ribosomes; then, incubate the sample for $15 \mathrm{~min}$ at $27^{\circ} \mathrm{C}$.

2. Centrifuge at $13,000 \times g$ for $5 \mathrm{~min}$ at $4{ }^{\circ} \mathrm{C}$. Thereafter, transfer the supernatant to a clean tube (puromycin-treated crude ribosomes, approximately $6 \mathrm{~mL}$ ).

3. Add approximately $4 \mathrm{~mL}$ of Butyl A buffer to the puromycin-treated crude ribosomes, such that the sample volume becomes $10 \mathrm{~mL}$. Then, slowly add $1.07 \mathrm{~g}$ of solid $\left(\mathrm{NH}_{4}\right)_{2} \mathrm{SO}_{4}$ (final concentration $1.4 \mathrm{M}$ ), mixing gently with a magnetic stirrer at $4{ }^{\circ} \mathrm{C}$.

4. Centrifuge the sample at $10,000 \times g$ for $10 \mathrm{~min}$ at $4{ }^{\circ} \mathrm{C}$. Then, transfer the supernatant to a clean tube.

5. Load the sample at a flow rate of $1.0 \mathrm{~mL} / \mathrm{min}$ onto a HiTrap Butyl FF column $(20 \mathrm{~mL}$, Cytiva) which has been equilibrated with $0 \%\left(1.4 \mathrm{M}\left(\mathrm{NH}_{4}\right)_{2} \mathrm{SO}_{4}\right)$ Butyl B buffer. 
6. Wash the column, at a flow rate of $2.5 \mathrm{~mL} / \mathrm{min}$, through the four successive steps: (i) wash with 10 column volumes of $0 \%\left(1.4 \mathrm{M}\left(\mathrm{NH}_{4}\right)_{2} \mathrm{SO}_{4}\right)$ Butyl B buffer; (ii) wash with 5 column volumes of $30 \%\left(980 \mathrm{mM}\left(\mathrm{NH}_{4}\right)_{2} \mathrm{SO}_{4}\right.$ ) Butyl B buffer; (iii) wash with a linear gradient from 30 to $37 \%$ (980 to $882 \mathrm{mM}\left(\mathrm{NH}_{4}\right)_{2} \mathrm{SO}_{4}$ ) Butyl B buffer in 5 column volumes; and (iv) wash with $37 \%$ B buffer with at least 10 column volumes, until the absorbance at $260 \mathrm{~nm}$ is near baseline.

7. Elute the ribosomes with a linear gradient from 37 to $50 \%$ (882 to $700 \mathrm{mM}\left(\mathrm{NH}_{4}\right)_{2} \mathrm{SO}_{4}$ ) Butyl B buffer in 10 column volumes, and then with another 6.8 column volumes of $50 \%$ B buffer, at a flow rate of $2.5 \mathrm{~mL} / \mathrm{min}$, collecting $4 \mathrm{~mL}$ fractions.

8. Pool the fractions with $A_{260} \geq 2$.

A CRITICAL STEP: be careful not to pool the fractions of $60 \mathrm{~S}$ subunits, which appear as the shoulder at the beginning of the major peak and whose $A_{260}$ are usually $<2$.

9. Transfer the $80 \mathrm{~S}$ pool into a $45 \mathrm{Ti}$ polycarbonate ultracentrifuge tube (BECKMAN COULTER). Add $50 \%$ B buffer, such that the sample volume becomes $50 \mathrm{~mL}$. If the volume of the $80 \mathrm{~S}$ pool is greater than $50 \mathrm{~mL}$, divide the sample into two 45Ti polycarbonate ultracentrifuge tubes and add $50 \%$ B buffer, such that the sample volume of each tube is $50 \mathrm{~mL}$.

10. Place $20 \mathrm{~mL}$ of sucrose cushion Buffer II at the very bottom of the 45Ti tube(s) using a syringe.

11. Centrifuge at $100,000 \times g(36,000 \mathrm{rpm}$, Type $45 \mathrm{Ti}$, BECKMAN COULTER) for $16 \mathrm{~h}$ at $4{ }^{\circ} \mathrm{C}$. Thereafter, aspirate off the supernatants.

12. Add approximately $50 \mu \mathrm{L}$ of $5 / 100$ buffer per tube and dissolve the pellets by gently shaking for approximately $1 \mathrm{~h}$ at $4{ }^{\circ} \mathrm{C}$, and then, transfer to clean tubes. Rinse the tube with a small amount of $5 / 100$ buffer (approximately $10 \mu \mathrm{L}$ ) and combine it with the recovered ribosomes.

13. Measure the $\mathrm{A}_{260}$ of the sample using a spectrometer and determine the concentration of $80 \mathrm{~S}$ ribosomes, estimating that the $80 \mathrm{~S}$ ribosomes at $1.0 \mathrm{~A}_{260}$ correspond to $20 \mathrm{pmol}$.

14. The purified $80 \mathrm{~S}$ ribosomes are aliquoted, fast-frozen in liquid nitrogen, and stored at $-80^{\circ} \mathrm{C}$. The yield is about $110 \mathrm{pmol} / \mathrm{L}$ culture (Table S2).

\section{Analysis of ribosomal proteins}

1. Add $2.5 \mu \mathrm{L}$ of $5 \times$ LiDS dye to 10 pmol of the purified $80 \mathrm{~S}$ ribosomes in $10 \mu \mathrm{L}$ of $5 / 100$ buffer and mix well.

2. Apply the sample to a $15 \%$ SDS-PAGE gel, and then, visualize the protein bands by CBB R-250 staining.

\section{Analysis of ribosomal RNAs}

1. Mix 10 pmol of the purified $80 \mathrm{~S}$ ribosomes, $250 \mu \mathrm{L}$ of RNase-free water, $25 \mu \mathrm{L}$ of $10 \%$ (wt/vol) SDS (final $1 \%$ ), and $2.5 \mu \mathrm{L}$ of $1 \mathrm{mg} / \mathrm{mL}$ of Proteinase K solution (final $10 \mu \mathrm{g} / \mathrm{mL})$.

2. Incubate for $15 \mathrm{~min}$ at $37^{\circ} \mathrm{C}$.

3. Add $750 \mu \mathrm{L}$ of ISOGEN-LS (NIPPON GENE) and vortex well.

4. After the incubation at room temperature for $5 \mathrm{~min}$, add $200 \mu \mathrm{L}$ of chloroform to the sample, and then, vortex well.

5. After the incubation at room temperature for $5 \mathrm{~min}$, centrifuge at $16,000 \times g$ for $10 \mathrm{~min}$ at $27^{\circ} \mathrm{C}$. Thereafter, remove the aqueous (upper) phase (approximately $400 \mu \mathrm{L}$ ) and transfer to a clean tube.

6. Add $40 \mu \mathrm{L}$ of $3 \mathrm{M} \mathrm{KOAc}(\mathrm{pH} 5.5$ ) and $500 \mu \mathrm{L}$ of ice-cold isopropanol to the sample and vortex well.

7. Centrifuge at $16,000 \times g$ for $30 \mathrm{~min}$ at $4{ }^{\circ} \mathrm{C}$. Thereafter, aspirate off the supernatant and save the pellet.

8. Add $1 \mathrm{~mL}$ of ice-cold $70 \%$ (vol/vol) ethanol to the sample.

9. Centrifuge at $16,000 \times g$ for $5 \mathrm{~min}$ at $4{ }^{\circ} \mathrm{C}$. Thereafter, aspirate off the supernatant and save the pellet. 
10. Add $40 \mu \mathrm{L}$ of RNase-free water and dissolve the ribosomal RNA pellet.

11. Mix $0.5 \mu \mathrm{L}$ of the sample, $4 \mu \mathrm{L}$ of RNase-free water, and $4.5 \mu \mathrm{L}$ of $2 x$ RNA loading dye.

12. Apply the resulting sample onto a $4 \%$ PAGE ( $8 \mathrm{M}$ urea) gel and run it at $190 \mathrm{~V}$ (constant voltage) until the $\mathrm{XC}$ dye reaches the bottom of the gel (approximately $1 \mathrm{~h}$ ).

13. Visualize the RNA bands by EtBr staining.

\section{Notes}

1. For typical results of the analysis of ribosomal proteins and ribosomal RNAs, refer to [18].

2. When verifying the ribosome activities, it is recommended to simultaneously examine the appropriate $\mathrm{Mg}^{2+}$ and polyamine concentration of the reaction, in order to recapitulate polyproline-mediated ribosome stalling; polyproline translation should be analyzed under the $\mathrm{Mg}^{2+}$ concentration of 5-7 mM in the presence of $0.25 \mathrm{mM}$ spermidine and $0 \mathrm{mM}$ spermine (see Figure 2). Refer to Section 3.4.3 for the translation reaction method and to Table S4 for the translation reaction conditions.

3. When extracting ribosomal RNAs for analysis, TRIzol LS (Thermo Fisher Scientific) can be used as an alternative to ISOGEN-LS.

\subsubsection{0. tRNAs}

\section{Cell culture}

1. From a glycerol stock, streak a sample of YPH499 yeast cells on a YPD plate and grow at $30^{\circ} \mathrm{C}$ for 2 days.

2. Collect the cells from the plate using a disposable loop, inoculate a $300 \mathrm{~mL}$ culture of YPD medium in a $500 \mathrm{~mL}$ flask with the cells, and then grow overnight (approximately $16 \mathrm{~h}$ ) at $30{ }^{\circ} \mathrm{C}$ with vigorous shaking at $170 \mathrm{rpm}$.

3. Inoculate six $900 \mathrm{~mL}$ cultures of YPD medium in $2 \mathrm{~L}$ baffled flasks with $20 \mathrm{~mL}$ of the overnight culture per flask, and then, grow at $30^{\circ} \mathrm{C}$ with vigorous shaking at $170 \mathrm{rpm}$, until the culture reaches an $\mathrm{OD}_{600}$ of 4.0. This should take approximately $9 \mathrm{~h}$.

4. Harvest the cells by centrifugation at $9000 \times g$ for $10 \mathrm{~min}$ at $4{ }^{\circ} \mathrm{C}$.

5. Resuspend with $1 \mathrm{~L}$ of $1 \%(\mathrm{wt} / \mathrm{vol}) \mathrm{KCl}$ and harvest the cells by centrifugation at $9000 \times g$ for $10 \min$ at $4{ }^{\circ} \mathrm{C}$.

6. Resuspend the cells with approximately $100 \mathrm{~mL}$ of lysis buffer and divide into six $50 \mathrm{~mL}$ tubes.

7. Harvest the cells by centrifugation at $9000 \times g$ for $10 \mathrm{~min}$ at $4{ }^{\circ} \mathrm{C}$. The pellet weight is about 4 g per tube.

(1) PAUSE STEP Frozen cells can be stored at $-80^{\circ} \mathrm{C}$ for approximately one month.

\section{Preparation of crude tRNAs}

1. Add $8 \mathrm{~mL}$ of $1 \mathrm{mM}$ Tris- $\mathrm{HCl}(\mathrm{pH} 7.5)-10 \mathrm{mM} \mathrm{Mg}(\mathrm{OAc})_{2}$ per tube ( $2 \mathrm{~mL}$ per $1 \mathrm{~g}$ cell pellet) and resuspend well.

2. Add $4 \mathrm{~mL}$ of phenol saturated with $1 \mathrm{mM}$ Tris- $\mathrm{HCl}(\mathrm{pH} 7.5)-10 \mathrm{mM} \mathrm{Mg}(\mathrm{OAc})_{2}$ per tube ( $1 \mathrm{~mL}$ per $1 \mathrm{~g}$ cell pellets) and vortex well.

3. Shake vigorously using a shaker overnight at $27^{\circ} \mathrm{C}$.

4. Centrifuge the samples at $8500 \times g$ for $30 \mathrm{~min}$ at $27^{\circ} \mathrm{C}$. Thereafter, transfer the aqueous phase to six clean tubes (approximately $10 \mathrm{~mL}$ per tube).

NOTE: Make sure that the supernatants are clear, in order to avoid DNA contamination.

5. Add $1 \mathrm{~mL}$ (1/10 volumes of sample) of $5 \mathrm{M} \mathrm{NaCl}$ and $20 \mathrm{~mL}$ (2 volumes of sample) of $100 \%$ (vol/vol) ethanol per tube, and then, vortex well.

6. Centrifuge the samples at $8500 \times g$ for $30 \mathrm{~min}$ at $27^{\circ} \mathrm{C}$. Thereafter, aspirate off the supernatants.

7. Add gently $10 \mathrm{~mL}$ of $100 \%$ (vol/vol) ethanol per tube.

8. Centrifuge the samples at $8500 \times g$ for $5 \mathrm{~min}$ at $4{ }^{\circ} \mathrm{C}$. Thereafter, aspirate off the supernatants. 
9. Dry the pellets for $5 \mathrm{~min}$ at $27^{\circ} \mathrm{C}$.

10. Resuspend the pellets with $5 \mathrm{~mL}$ of $1 \mathrm{M} \mathrm{NaCl}$ per tube.

11. Centrifuge the samples at $8500 \times g$ for $30 \mathrm{~min}$ at $4{ }^{\circ} \mathrm{C}$. Thereafter, transfer the supernatant to six clean tubes (approximately $5 \mathrm{~mL}$ per tube).

NOTE: Here, high molecular weight RNAs are selectively precipitated as the pellets.

12. Add $10 \mathrm{~mL}$ (2 volumes of sample) of $100 \%$ (vol/vol) ethanol per tube and vortex well.

13. Centrifuge the samples at $8500 \times g$ for $30 \mathrm{~min}$ at $4{ }^{\circ} \mathrm{C}$. Thereafter, aspirate off the supernatants.

14. Resuspend the pellets with $8 \mathrm{~mL}$ of $1.8 \mathrm{M}$ Tris- $\mathrm{HCl}(8.0)$ per tube.

15. Incubate the samples at $37{ }^{\circ} \mathrm{C}$ for $1.5 \mathrm{~h}$, in order to deacylate the endogenous aminoacyl-tRNAs.

16. Add $800 \mu \mathrm{L}$ of $5 \mathrm{M} \mathrm{NaCl}$ and $20 \mathrm{~mL}$ of $100 \%$ (vol/vol) ethanol per tube and vortex well.

17. Centrifuge the samples at $8500 \times g$ for $30 \mathrm{~min}$ at $4{ }^{\circ} \mathrm{C}$. Thereafter, aspirate off the supernatants.

(1) PAUSE STEP Freeze the sample and they can be stored at $-80^{\circ} \mathrm{C}$ for approximately 1 day.

18. Resuspend the pellets with $25 \mathrm{~mL}$ of HiTrap Q A buffer.

19. Quantify the crude tRNAs using a spectrometer. The yield is about $800 \mathrm{~A}_{260}$ units.

\section{Purification of tRNAs by HiTrap $Q$ column chromatography}

1. Load the sample at a flow rate of $1.0 \mathrm{~mL} / \mathrm{min}$ onto a HiTrap Q HP column $(15 \mathrm{~mL}$, Cytiva) which has been equilibrated with $0 \%(200 \mathrm{mM} \mathrm{NaCl}) \mathrm{Q} B$ buffer.

NOTE: no more than $70 \mathrm{~A}_{260}$ units of sample should be loaded per $1 \mathrm{~mL}$ of resin.

2. After washing with 5 column volumes of $0 \%(200 \mathrm{mM} \mathrm{NaCl}) \mathrm{Q} B$ buffer, wash further with a linear gradient from 0 to $20 \%$ ( 200 to $360 \mathrm{mM} \mathrm{NaCl}$ ) Q B buffer in 2.5 column volumes at a flow rate of $2.0 \mathrm{~mL} / \mathrm{min}$.

3. Elute the tRNAs with a linear gradient from 20 to $35 \%$ (360 to $480 \mathrm{mM} \mathrm{NaCl}$ ) Q B buffer in 9 column volumes, with an additional linear gradient from 35 to $45 \%$ ( 480 to $560 \mathrm{mM} \mathrm{NaCl}$ ) Q B buffer in 7.25 column volumes, at a flow rate of $2.0 \mathrm{~mL} / \mathrm{min}$, collecting $3 \mathrm{~mL}$ fractions.

4. Wash the column with a linear gradient from 45 to $100 \%(560 \mathrm{mM}$ to $1 \mathrm{M} \mathrm{NaCl}) \mathrm{Q}$ B buffer in 1.25 column volumes, and with 1 column volume of $100 \%(1 \mathrm{M} \mathrm{NaCl}) \mathrm{Q}$ B buffer.

5. Identify the fractions containing tRNAs by analyzing the aliquots $(5 \mu \mathrm{L})$ of fractions by $10 \%$ PAGE ( $8 \mathrm{M}$ urea) and staining with EtBr. tRNAs are typically eluted from 30 to $40 \%$ B buffer. Pool fractions that contain tRNAs; the volume of the pool is approximately $110 \mathrm{~mL}$.

A CRITICAL STEP Be careful not to collect longer RNAs, including 5S RNA, which elute following the major peak of tRNAs at about $40 \% \mathrm{~B}$ buffer.

6. Add 0.1 volumes of $3 \mathrm{M} \mathrm{NaOAc}$ ( $\mathrm{pH}$ 5.5) and an equal volume of ice-cold isopropanol to the samples and mix well.

7. Allow the sample to cool sufficiently at $-30{ }^{\circ} \mathrm{C}$ overnight (or in liquid nitrogen for a while).

8. Centrifuge the samples at $7500 \times g$ for $1 \mathrm{~h}$ at $4{ }^{\circ} \mathrm{C}$. Thereafter, aspirate off the supernatants.

9. Resuspend the pellets with $1.5 \mathrm{~mL}$ of HiTrap Q A buffer.

10. Add $150 \mu \mathrm{L}$ ( 0.1 volumes) of $3 \mathrm{M} \mathrm{NaOAc}$ ( $\mathrm{pH}$ 5.5) and $3 \mathrm{~mL}$ (two volumes) of ice-cold ethanol to the samples and mix well. Divide the sample into two $5 \mathrm{~mL}$ tubes.

11. Centrifuge the samples at $15,000 \times g$ for $1 \mathrm{~h}$ at $4{ }^{\circ} \mathrm{C}$. Thereafter, aspirate off the supernatants.

12. Add $2 \mathrm{~mL}$ of ice-cold $70 \%$ (vol/vol) ethanol per tube and vortex well.

13. Centrifuge the samples at $15,000 \times g$ for $20 \mathrm{~min}$ at $4{ }^{\circ} \mathrm{C}$. Thereafter, aspirate off the supernatants. Remove as much ethanol as possible. 
14. Dry the pellets at $27^{\circ} \mathrm{C}$ for approximately $5 \mathrm{~min}$. Do not over-dry the pellets; they should be slightly wet.

15. Dissolve the pellets with a total of $600 \mu \mathrm{L}$ RNase-free water.

16. Measure the $\mathrm{A}_{260}$ of the sample using a spectrometer, and determine the concentration of tRNAs.

17. The samples are aliquoted, fast-frozen in liquid nitrogen, and stored at $-80^{\circ} \mathrm{C}$. The yield is about $120 \mathrm{~A}_{260}$ units/L culture (Table S2).

\section{Analysis of tRNAs}

1. Add $5 \mu \mathrm{L}$ of $2 \times \mathrm{RNA}$ loading dye to $0.01 \mathrm{~A}_{260}$ units of the sample and mix well.

2. Apply the resulting sample onto a $10 \%$ PAGE (8M urea) gel and run it at $200 \mathrm{~V}$ (constant voltage) until the BPB dye reaches the bottom of the gel (approximately $40 \mathrm{~min})$.

3. Visualize the tRNA bands by EtBr staining.

\section{Notes}

1. For typical results of the PAGE analysis of tRNAs, refer to [18].

2. Examine the aminoacylation efficiency of the tRNAs by analyzing the charging of $\left[{ }^{35}\right.$ S]Met, according to the "preparation of aminoacyl-tRNA" section.

\subsection{Aminoacyl-tRNAs}

\section{Preparation of S100 yeast lysate \\ Cell culture}

1. From a glycerol stock, streak a sample of YPH499 yeast cells on a YPD plate and grow at $30{ }^{\circ} \mathrm{C}$ for 2 days.

2. Collect the cells from the plate using a disposable loop, inoculate a $300 \mathrm{~mL}$ culture of YPD medium in a $500 \mathrm{~mL}$ flask with the cells, and then grow overnight (approximately $16 \mathrm{~h}$ ) at $30^{\circ} \mathrm{C}$ with vigorous shaking at $170 \mathrm{rpm}$.

3. Inoculate twelve $900 \mathrm{~mL}$ cultures of YPD medium in $2 \mathrm{~L}$ baffled flasks with $20 \mathrm{~mL}$ of the overnight culture per flask, and then, grow at $30{ }^{\circ} \mathrm{C}$ with vigorous shaking at $170 \mathrm{rpm}$, until the culture reaches an $\mathrm{OD}_{600}$ of 4.0. This should take approximately $9 \mathrm{~h}$.

4. Harvest the cells by centrifugation at $9000 \times g$ for $10 \mathrm{~min}$ at $4{ }^{\circ} \mathrm{C}$.

5. Resuspend with $1 \mathrm{~L}$ of $1 \%(\mathrm{wt} / \mathrm{vol}) \mathrm{KCl}$ and harvest the cells by centrifugation at $9000 \times g$ for $10 \mathrm{~min}$ at $4{ }^{\circ} \mathrm{C}$.

6. Resuspend with $1 \mathrm{~L}$ of lysis buffer and harvest the cells by centrifugation at $9000 \times g$ for $10 \mathrm{~min}$ at $4{ }^{\circ} \mathrm{C}$. The pellet weight should be $4.0 \mathrm{~g} / \mathrm{L}$ culture.

7. Resuspend with an equal amount of lysis buffer ( $1 \mathrm{~mL}$ buffer per $1 \mathrm{~g}$ of cells) and dispense the cells through micropipettes into liquid nitrogen to form frozen yeast droplets.

(I) PAUSE STEP Frozen cells can be stored at $-80^{\circ} \mathrm{C}$ for approximately one month.

\section{Preparation of S100 lysate}

1. Disrupt the cells by mechanical grinding (see Appendix A).

2. Thaw the frozen powder of ground cells at $4{ }^{\circ} \mathrm{C}$ and centrifuge at $7500 \times g$ for $10 \mathrm{~min}$ at $4{ }^{\circ} \mathrm{C}$. Thereafter, transfer the supernatants to a clean tube (Sup 1, approximately $40 \mathrm{~mL}$ ).

3. Resuspend the resulting pellets with $20 \mathrm{~mL}$ of lysis buffer and centrifuge at $7500 \times$ $g$ for $10 \mathrm{~min}$ at $4{ }^{\circ} \mathrm{C}$. Thereafter, transfer the supernatants to a clean tube (Sup 2, approximately $20 \mathrm{~mL}$ ).

4. Combine Sup 1 and Sup 2 and transfer to a clean ultracentrifuge tube. Centrifuge at 20,000 $\times g\left(16,000 \mathrm{rpm}\right.$, Type 45Ti, BECKMAN COULTER) for $30 \mathrm{~min}$ at $4{ }^{\circ} \mathrm{C}$. Thereafter, transfer the supernatants to a clean tube (approximately $50-60 \mathrm{~mL}$ ). 
NOTE: Take care to minimize contamination from either the lipid fraction at the very top or the cell debris at the bottom of the tube.

5. Centrifuge the samples at $65,000 \times g(29,000 \mathrm{rpm}$, Type $45 \mathrm{Ti}$, BECKMAN COULTER $)$ for $5 \mathrm{~h}$ at $4{ }^{\circ} \mathrm{C}$. Thereafter, transfer the top two-thirds of the supernatant to a clean tube (approximately $45 \mathrm{~mL}$ ).

NOTE: Take care to minimize contamination from either the lipid fraction at the very top or the cell debris at the bottom of the tube.

6. Dialyze the sample against $2 \mathrm{~L}$ of Buffer $\mathrm{A}$ at $4{ }^{\circ} \mathrm{C}$ overnight, with a change of buffer after $1 \mathrm{~h}$.

7. OPTIONAL STEP: Clarify the sample by centrifugation at $10,000 \times g$ for $15 \mathrm{~min}$ at $4{ }^{\circ} \mathrm{C}$.

8. Mix the sample and $10 \mathrm{~mL}$ of $\mathrm{Q}$ sepharose Fast Flow resin (Cytiva) equilibrated with Buffer $\mathrm{A}(250 \mathrm{mM} \mathrm{NaCl})$ on a rotator at $4{ }^{\circ} \mathrm{C}$ for approximately $30 \mathrm{~min}$.

9. Sediment the resin by centrifugation at $500 \times g$ for $10 \mathrm{~min}$, and then, transfer the supernatant to a clean tube (flow-through Fraction 1, approximately $40 \mathrm{~mL}$ ).

10. Add 1 column volume of Buffer $\mathrm{A}(250 \mathrm{mM} \mathrm{NaCl})$ to the resin and gently mix the slurry. Sediment the resin by centrifugation at $500 \times g$ for $10 \mathrm{~min}$, and then, transfer the supernatant to a clean tube (flow-through Fraction 2, approximately $10 \mathrm{~mL}$ ).

11. Combine the flow-through Fractions 1 and 2 (approximately $50 \mathrm{~mL}$ ).

12. Measure the concentration of the sample by the Bradford Assay.

13. The samples are aliquoted in approximately single-use aliquots $(50 \mu \mathrm{L})$, fast-frozen in liquid nitrogen, and stored at $-80^{\circ} \mathrm{C}$, where they usually remain stable for months. The yield of proteins in the S100 lysate is approximately $30 \mathrm{mg}$ from $1 \mathrm{~L}$ culture (Table S2).

\section{Notes}

1. Measure the aminoacylation activity of S100 lysate according to the "preparation of aminoacyl-tRNAs" section.

\section{Preparation of aminoacyl-tRNAs}

1. Prepare "buffer mixture" and "enzyme mixture" (total $1 \mathrm{~mL}$ ) on ice, as follows (Table 1)

2. Mix "buffer mixture" and "enzyme mixture", and then, incubate at $30{ }^{\circ} \mathrm{C}$ for $30 \mathrm{~min}$.

3. Add $3 \mathrm{~mL}$ of solution $\mathrm{D}$ and $300 \mu \mathrm{L}$ of $2 \mathrm{M} \mathrm{NaOAc}(\mathrm{pH} 4.0)$ to the reaction mixture, and then, mix well.

4. Add $4.3 \mathrm{~mL}$ of phenol saturated with $50 \mathrm{mM} \mathrm{KOAc}(\mathrm{pH} 5.5)$ and $860 \mu \mathrm{L}$ of CIA (chloroform:isoamyl alcohol, 49:1) to the sample, and then, vortex well.

5. Centrifuge the sample at maximum speed $(\sim 15,000 \times g)$ for 5 min at $27^{\circ} \mathrm{C}$. Thereafter, transfer the aqueous (upper) phase to a clean tube.

6. Add $4.3 \mathrm{~mL}$ of ice-cold isopropanol to the sample and vortex well.

7. Centrifuge the sample at maximum speed $(\sim 15,000 \times g)$ for $30 \mathrm{~min}$ at $4{ }^{\circ} \mathrm{C}$. Thereafter, aspirate off the supernatant.

8. Dry the pellet for $5 \mathrm{~min}$ at $27^{\circ} \mathrm{C}$.

9. Resuspend the pellet with $300 \mu \mathrm{L}$ of ice-cold $50 \mathrm{mM} \mathrm{KOAc} \mathrm{(pH} \mathrm{5.5).}$

10. Prepare two NAP-5 columns (Cytiva), and equilibrate each column with $10 \mathrm{~mL}$ of ice-cold equilibration buffer ( $0.3 \mathrm{M} \mathrm{KOAc}(\mathrm{pH} 5.5) — 5 \%$ (vol/vol) isopropanol).

$\triangle$ CRITICAL STEP: it is recommended that the columns be set in a cold room.

11. Load $150 \mu \mathrm{L}$ of sample per column and allow the sample to enter the gel bed completely.

12. Load $350 \mu \mathrm{L}$ of ice-cold equilibration buffer per column, such that combined volume of the sample and equilibration buffer equals $500 \mu \mathrm{L}$. Allow the equilibration buffer to enter the gel bed completely.

13. Elute with $560 \mu \mathrm{L}$ of ice-cold equilibration buffer per column, collecting the sample in a $5 \mathrm{~mL}$ tube. 
14. Add 2 volumes $(1.12 \mathrm{~mL})$ of ice-cold $100 \%$ ethanol to the eluate per tube and vortex well.

15. Centrifuge the sample at maximum speed $(\sim 15,000 \times g)$ for $30 \mathrm{~min}$ at $4{ }^{\circ} \mathrm{C}$. Thereafter, aspirate off the supernatant.

16. Gently add $2 \mathrm{~mL}$ of ice-cold $70 \%$ (vol/vol) ethanol per tube, to rinse the pellet.

17. Centrifuge the sample at maximum speed $(\sim 15,000 \times g)$ for 5 min at $4{ }^{\circ} \mathrm{C}$. Thereafter, aspirate off the supernatant. Remove as much ethanol as possible.

18. Dry the pellet for $5 \mathrm{~min}$ at $27^{\circ} \mathrm{C}$. Do not over-dry the pellets; they should be slightly wet.

19. Resuspend the pellet with $100 \mu \mathrm{L}$ of ice-cold $50 \mathrm{mM} \mathrm{KOAc}(\mathrm{pH}$ 5.5).

20. The aminoacyl-tRNAs are aliquoted in approximately single-use aliquots $(60 \mu \mathrm{L})$, fast-frozen in liquid nitrogen, and stored at $-80{ }^{\circ} \mathrm{C}$, where they usually remain stable for months.

Table 1. Components in the aminoacylation reaction.

\begin{tabular}{|c|c|c|}
\hline & Components & Volume $(\mu \mathrm{L})$ \\
\hline \multirow{10}{*}{ Buffer mixture } & $\begin{array}{c}1.5 \text { mM } 18 \text { a.a } \\
\text { (without Met and Cys) }\end{array}$ & 100 \\
\hline & 10 mM Cysteine & 10 \\
\hline & tRNAs from yeast & (6.25 $\mathrm{A}_{260}$ units) \\
\hline & $10 \times$ NTPs & 100 \\
\hline & $\begin{array}{c}12 \% \text { PURE buffer } \\
\text { (without Mg and SPD) }\end{array}$ & 120 \\
\hline & $1 \mathrm{M}$ Creatine phosphate & 20 \\
\hline & $500 \mathrm{mM} \mathrm{Mg}(\mathrm{OAc})_{2}$ & $X($ final $9 \mathrm{mM}) * 1$ \\
\hline & $20 \mathrm{mM}$ spermidine & 100 \\
\hline & $10 \mathrm{mM}$ spermine & 10 \\
\hline & {$\left[{ }^{35}\right.$ S]methionine ${ }^{* 2}$} & 50 \\
\hline \multirow{8}{*}{ Enzyme mixture } & RNase-free water & (to $1 \mathrm{~mL}$ ) \\
\hline & Creatine kinase & (final $100 \mathrm{nM}$ ) \\
\hline & Myokinase & (final $20 \mathrm{nM}$ ) \\
\hline & Nucleoside-diphosphate kinase & (final $15 \mathrm{nM}$ ) \\
\hline & Pyrophosphatase & (final $15 \mathrm{nM}$ ) \\
\hline & eEF1A & (final $0.5 \mu \mathrm{M}$ ) \\
\hline & Recombinant RNase Inhibitor & 20 \\
\hline & S100 & 50 \\
\hline
\end{tabular}

*1 The components listed in Table S5 are dissolved in stock buffer containing the indicated $\mathrm{Mg}^{2+}$ concentrations $[1,4,18] . \mathrm{X}$ is determined by taking into account the concentration of $\mathrm{Mg}^{2+}$ derived from the components, such that the final concentration of $\mathrm{Mg}^{2+}$ in the reaction is $9 \mathrm{mM} .{ }^{* 2}$ When preparing the unlabeled aminoacyl-tRNAs, add $50 \mu \mathrm{L}$ of $1 \mathrm{mM}$ methionine, instead of $\left[{ }^{35} \mathrm{~S}\right]$ methionine.

\section{Evaluation of aminoacylation efficiency by analysis of the $\left[{ }^{35} \mathrm{~S}\right]$ Methionine charging}

1. Dilute $1 \mu \mathrm{L}$ of the aminoacyl-tRNAs 100-fold with $50 \mathrm{mM}$ KOAc (pH 5.5).

2. Spot $1 \mu \mathrm{L}$ of the resulting sample on Whatman 3MM chromatography paper $(1 \mathrm{~cm} \times 1 \mathrm{~cm})($ Whatman$)$.

3. Immerse the paper in ice-cold 10\% (vol/vol) TCA and gently shake for 10 min on ice.

4. Change the ice-cold $10 \%$ (vol/vol) TCA and gently shake for $10 \mathrm{~min}$ on ice.

5. Immerse the paper in ice-cold $70 \%(\mathrm{vol} / \mathrm{vol})$ ethanol and gently shake for $10 \mathrm{~min}$ on ice.

6. Dry up the paper completely under a heat lamp (approximately $15 \mathrm{~min}$ ).

7. Transfer the dried paper into a plastic scintillation vial containing $5 \mathrm{~mL}$ of Ultima Gold scintillation cocktail (PerkinElmer). In parallel, in order to measure the specific 
radioactivity of radioisotopic methionine, undiluted $\left[{ }^{35} \mathrm{~S}\right]$ methionine stock solution is diluted 10,000-fold with RNase-free water, and $1 \mu \mathrm{L}$ of the dilution corresponding to $8.5 \times 10^{-4} \mathrm{pmol}\left[{ }^{35} \mathrm{~S}\right]$ methionine is transferred into another plastic scintillation vial containing $5 \mathrm{~mL}$ of Ultima Gold.

8. Vigorously shake the samples for $30 \mathrm{~min}$ at $27^{\circ} \mathrm{C}$.

9. Measure the radioactivity of the samples using a scintillation counter.

\section{Notes}

1. Approximately 8 pmol of $\left[{ }^{35} \mathrm{~S}\right]$ methionine is usually charged per one $\mathrm{A}_{260}$ unit of tRNA mixture.

2. If the aminoacylation efficiency is inefficient, the volume of $\mathrm{S} 100$ in the reaction can be increased up to $1 / 5$ reaction volumes $(200 \mu \mathrm{L})$.

3. Verify the translation ability of the aminoacyl-tRNAs, referring to Section 3.4.3 for the translation reaction method, and to Table S4 for the translation reaction condition.

\subsection{Preparation of CrPV-IRES Containing mRNA}

Prepare the desired mRNAs by in vitro transcription using T7 RNA polymerase and the template DNAs, according to the standard protocols (for details, see Appendix B). The template DNA sequences for the mRNAs used in Figure 2 are shown in Table S6.

\subsection{In Vitro Translation}

\subsubsection{Transcription-Aminoacylation-Translation Coupled Reaction}

The protocols in this section describe a standard reaction, where a DNA template and T7 RNA polymerase are included for the mRNA transcription, and human aminoacyltRNA synthetase mixture [4] is included for aminoacylation. The $\mathrm{Mg}^{2+}$ and polyamine concentration in the reaction, $[\mathrm{Mg} / \mathrm{SPD} / \mathrm{SP}]$, is set as $[9 / 2 / 0.1]$, in order to sustain the efficient transcription and aminoacylation reactions. Note that polyproline-mediated translation arrest is not recapitulated under this condition.

1. Prepare the "buffer mixture," "enzyme mixture," and "DNA solution" (total $20 \mu \mathrm{L}$ ) on ice, as follows (Table 2):

Table 2. Components in the "Transcription-Aminoacylation-Translation Coupled Reaction".

\begin{tabular}{|c|c|c|}
\hline & Components & Volume $(\mu \mathrm{L})$ \\
\hline \multirow{10}{*}{ Buffer mixture } & $\begin{array}{l}1.5 \mathrm{mM} 18 \text { a.a. } \\
\text { (without Met and Cys) }\end{array}$ & 2 \\
\hline & 10 mM Cys & 0.2 \\
\hline & Yeast tRNAs & (0.125 $\mathrm{A}_{260}$ units) \\
\hline & $10 \times$ NTPs & 2 \\
\hline & $\begin{array}{c}\text { 12\% PURE buffer } \\
\text { (without Mg and SPD) }\end{array}$ & 2.4 \\
\hline & $1 \mathrm{M}$ Creatine phosphate & 0.4 \\
\hline & $250 \mathrm{mM} \mathrm{Mg}(\mathrm{OAc})_{2}$ & $X * 1$ (final $9 \mathrm{mM})$ \\
\hline & 20 mM SPD & 2 \\
\hline & $10 \mathrm{mM} \mathrm{SP}$ & 0.2 \\
\hline & $1 \mathrm{mM} \mathrm{Met}^{* 2}$ & 1 \\
\hline
\end{tabular}


Table 2. Cont.

\begin{tabular}{|c|c|c|}
\hline & Components & Volume $(\mu \mathrm{L})$ \\
\hline \multirow{15}{*}{ Enzyme mixture } & T7 RNA polymerase & (final $30 \mathrm{nM}$ ) \\
\hline & Creatine kinase & (final $100 \mathrm{nM}$ ) \\
\hline & Myokinase & (final $20 \mathrm{nM}$ ) \\
\hline & Nucleoside-diphosphate kinase & (final $15 \mathrm{nM}$ ) \\
\hline & Pyrophosphatase & (final $15 \mathrm{nM}$ ) \\
\hline & eEF1A & (final $5.0 \mu \mathrm{M}$ ) \\
\hline & eEF2 & (final $0.5 \mu \mathrm{M}$ ) \\
\hline & eEF3 & (final $0.5 \mu \mathrm{M}$ ) \\
\hline & eRF1 & (final $0.5 \mu \mathrm{M}$ ) \\
\hline & eRF3 & (final $0.5 \mu \mathrm{M}$ ) \\
\hline & Dom34 & (final $0.5 \mu \mathrm{M}$ ) \\
\hline & Hbs1 & (final $0.5 \mu \mathrm{M}$ ) \\
\hline & Rli1 & (final $0.5 \mu \mathrm{M}$ ) \\
\hline & $80 \mathrm{~S}$ ribosome & (final $0.5 \mu \mathrm{M}$ ) \\
\hline & ARS human mix & (final $0.05 \mathrm{mg} / \mathrm{mL}$ ) \\
\hline \multirow{2}{*}{ DNA solution } & Template DNA & (final $0.1 \mathrm{nM}$ ) \\
\hline & RNase-free water & (to $20 \mu \mathrm{L}$ ) \\
\hline
\end{tabular}

*1 The components listed in Table S5 are dissolved in stock buffer containing the indicated $\mathrm{Mg}^{2+}$ concentrations $[1,4,18] . X$ is determined by taking into account the concentration of $\mathrm{Mg}^{2+}$ derived from the components, such that the final concentration of $\mathrm{Mg}^{2+}$ in the reaction is $9 \mathrm{mM} .{ }^{* 2}$ When analyzing the $\left.{ }^{35} \mathrm{~S}\right]$ methionine-labelled translation products, add $1 \mu \mathrm{L}$ of $\left[{ }^{35} \mathrm{~S}\right]$ methionine (PerkinElmer, NEG009A) instead of cold methionine.

2. Mix "buffer mixture," "DNA solution," and "enzyme mixture," in this order, on ice.

3. Incubate the reaction mixture at $30^{\circ} \mathrm{C}$ for an appropriate time $(2-4 \mathrm{~h})$.

4. Put the sample on ice, to stop the reaction, at an appropriate time point.

\subsubsection{Aminoacylation-Translation Coupled Reaction}

The protocols in this section describe a standard reaction, where human aminoacyltRNA synthetase mixture [4] is included for aminoacylation. mRNAs are utilized in the reaction, instead of DNA template and T7 RNA polymerase. The $\mathrm{Mg}^{2+}$ and polyamine concentration in the reaction, $[\mathrm{Mg} / \mathrm{SPD} / \mathrm{SP}]$, is set as $[9 / 2 / 0.1]$, in order to sustain the efficient aminoacylation reactions. Note that polyproline-mediated translation arrest is not recapitulated under this condition.

1. Prepare the "buffer mixture," "enzyme mixture," and "mRNA solution" (total $20 \mu \mathrm{L}$ ) on ice, as follows (Table 3):

2. Mix "buffer mixture," "enzyme mixture," and "mRNA solution," in this order, on ice.

3. Incubate the reaction mixture at $30^{\circ} \mathrm{C}$ for an appropriate time $(2-4 \mathrm{~h})$.

4. Put the sample on ice, to stop the reaction, at an appropriate time point. 
Table 3. Components in the "Aminoacylation-Translation Coupled Reaction".

\begin{tabular}{|c|c|c|}
\hline & Components & Volume $(\mu \mathrm{L})$ \\
\hline \multirow{10}{*}{ Buffer mixture } & $\begin{array}{l}1.5 \mathrm{mM} 18 \text { a.a. } \\
\text { (without Met and Cys) }\end{array}$ & 2 \\
\hline & 10 mM Cys & 0.2 \\
\hline & Yeast tRNAs & (0.125 $\mathrm{A}_{260}$ units) \\
\hline & 20 mM ATP, GTP & 1 \\
\hline & $\begin{array}{c}12 \% \text { PURE buffer } \\
\text { (without Mg and SPD) }\end{array}$ & 2.4 \\
\hline & 1 M Creatine phosphate & 0.4 \\
\hline & $250 \mathrm{mM} \mathrm{Mg}(\mathrm{OAc})_{2}$ & $X * 1$ (final $9 \mathrm{mM})$ \\
\hline & 20 mM SPD & 2 \\
\hline & $10 \mathrm{mM} \mathrm{SP}$ & 0.2 \\
\hline & $1 \mathrm{mM} \mathrm{Met} * 2$ & 1 \\
\hline \multirow{14}{*}{ Enzyme mixture } & Creatine kinase & (final $100 \mathrm{nM}$ ) \\
\hline & Myokinase & (final $20 \mathrm{nM}$ ) \\
\hline & Nucleoside-diphosphate kinase & (final $15 \mathrm{nM}$ ) \\
\hline & Pyrophosphatase & (final $15 \mathrm{nM}$ ) \\
\hline & eEF1A & (final $5.0 \mu \mathrm{M}$ ) \\
\hline & eEF2 & (final $0.5 \mu \mathrm{M}$ ) \\
\hline & eEF3 & (final $0.5 \mu \mathrm{M}$ ) \\
\hline & eRF1 & (final $0.5 \mu \mathrm{M}$ ) \\
\hline & eRF3 & (final $0.5 \mu \mathrm{M}$ ) \\
\hline & Dom34 & (final $0.5 \mu \mathrm{M}$ ) \\
\hline & Hbs1 & (final $0.5 \mu \mathrm{M}$ ) \\
\hline & Rli1 & (final $0.5 \mu \mathrm{M}$ ) \\
\hline & $80 \mathrm{~S}$ ribosome & (final $0.5 \mu \mathrm{M}$ ) \\
\hline & ARShuman mix & (final $0.05 \mathrm{mg} / \mathrm{mL}$ ) \\
\hline \multirow{2}{*}{ mRNA solution } & mRNA & (final $0.25-0.5 \mu \mathrm{M}$ ) \\
\hline & RNase-free water & (to $20 \mu \mathrm{L}$ ) \\
\hline
\end{tabular}

*1 The components listed in Table S5 are dissolved in stock buffer containing the indicated $\mathrm{Mg}^{2+}$ concentrations $[1,4,18] . X$ is determined by taking into account the concentration of $\mathrm{Mg}^{2+}$ derived from the components, such that the final concentration of $\mathrm{Mg}^{2+}$ in the reaction is $9 \mathrm{mM} .{ }^{* 2}$ When analyzing the $\left.{ }^{35} \mathrm{~S}\right]$ methionine-labelled translation products, add $1 \mu \mathrm{L}$ of $\left[{ }^{35} \mathrm{~S}\right]$ methionine (PerkinElmer, NEG009A) instead of cold methionine.

\subsubsection{Translation Reaction without Coupled Reaction}

The protocols in this section describe a standard reaction where the translation reaction is separated from transcription and aminoacylation reactions; mRNAs are utilized instead of DNA template and T7 RNA polymerase, and a pre-charged aminoacyl-tRNA mixture is used instead of a human aminoacyl-tRNA synthetase mixture [4]. The $\mathrm{Mg}^{2+}$ and polyamine concentration in the reaction, $[\mathrm{Mg} / \mathrm{SPD} / \mathrm{SP}]$, is usually set as $[5-7 / 0.25 / 0]$, such that polyproline-mediated translation arrest is properly recapitulated. The precise $\mathrm{Mg}^{2+}$ concentration needs to be determined, depending on the lot of $80 \mathrm{~S}$ ribosome preparation (see Figure 2).

1. Prepare the "buffer mixture," "enzyme mixture," "aminoacyl-tRNA mixture," and "mRNA solution" (total $20 \mu \mathrm{L}$ ) on ice, as follows (Table 4): 
Table 4. Components in the "Translation Reaction without Coupled Reaction".

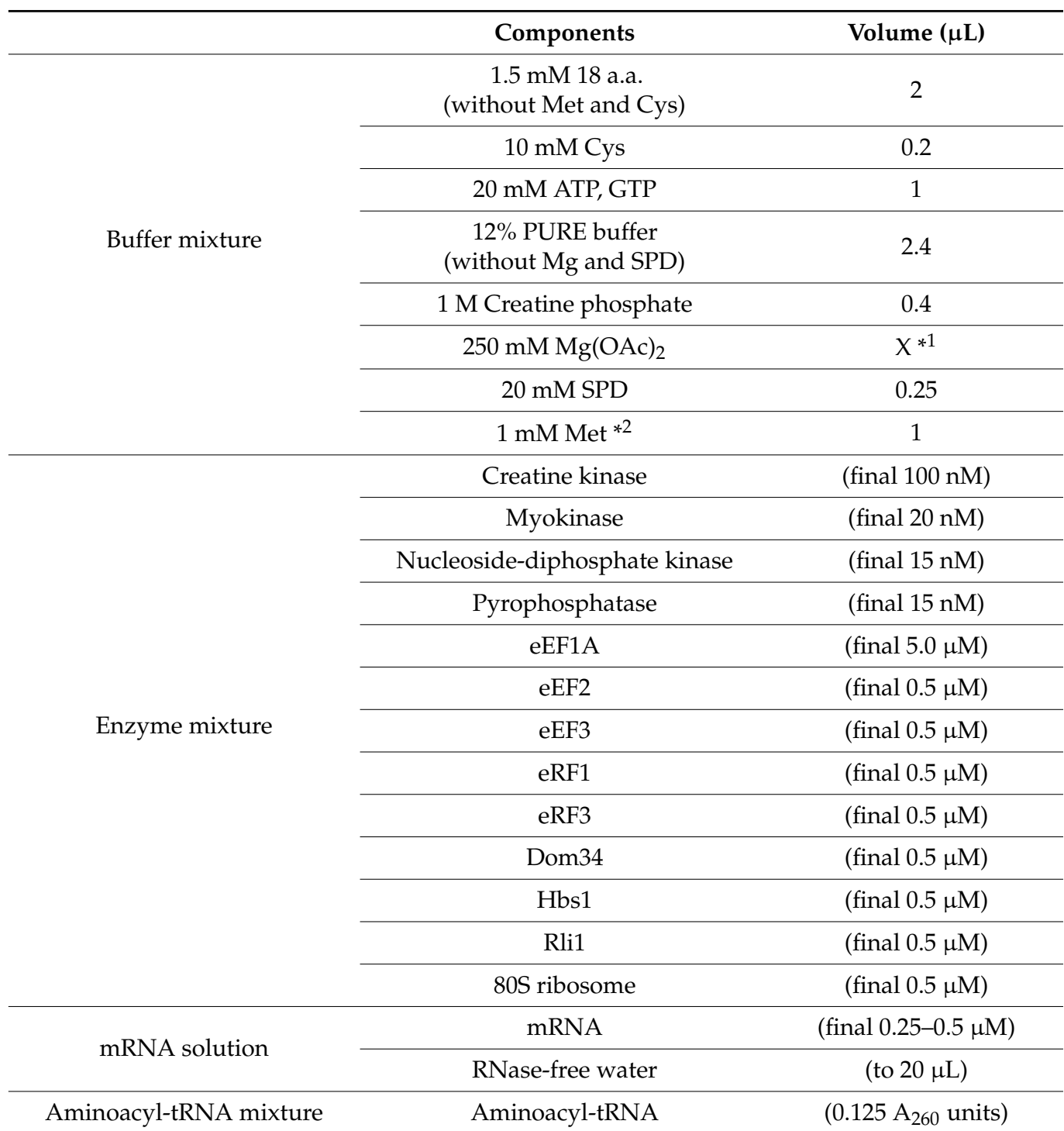

*1 The components listed in Table S5 are dissolved in stock buffer containing the indicated $\mathrm{Mg}^{2+}$ concentrations $[1,4,18] . X$ is determined by taking into account the concentration of $\mathrm{Mg}^{2+}$ derived from the components, such that the final concentration of $\mathrm{Mg}^{2+}$ in the reaction is the desired concentration (usually 5-7 mM). ${ }^{* 2}$ When analyzing the $\left.{ }^{35} \mathrm{~S}\right]$ methionine-labelled translation products, add $1 \mu \mathrm{L}$ of $\left[{ }^{35} \mathrm{~S}\right]$ methionine (PerkinElmer, NEG009A), instead of cold methionine.

2. Mix "buffer mixture," "enzyme mixture," "mRNA solution," and "aminoacyl-tRNA mixture," in this order, on ice.

3. Incubate the reaction mixture at $30^{\circ} \mathrm{C}$ for an appropriate time $(2-4 \mathrm{~h})$.

4. Put the sample on ice, to stop the reaction, at an appropriate time point.

\subsection{Analysis of Translation Products}

3.5.1. Measurement of Nanoluciferase Activity

1. After the translation reaction, mix $2 \mu \mathrm{L}$ of the translation reaction sample and $18 \mu \mathrm{L}$ of $0.1 \mathrm{mg} / \mathrm{mL}$ RNase A, to stop the reaction, on ice.

2. Prepare a Nano-Glo Substrate-Buffer mixture, which contains Nano-Glo Luciferase Assay Substrate (Promega) and Nano-Glo Luciferase Assay Buffer (Promega) in a ratio of 1:50. Mix the sample in Step $1(20 \mu \mathrm{L})$ and $20 \mu \mathrm{L}$ of Nano-Glo Substrate-Buffer mixture on ice.

3. Apply the sample into a white 96 -well half-area plate and incubate for $17 \mathrm{~min}$ at $27^{\circ} \mathrm{C}$. 
4. Measure the nanoluciferase activity using a GloMax platereader (Promega) (PROTOCOLS: Nano-Glo/Integration Time: 0.3 s).

\section{Notes}

1. When analyzing the time course of the nanoluciferase synthesis, withdraw $2 \mu \mathrm{L}$ from the reaction solution at the desired time point. At this time, gently open the lid of the reaction tube, and do not remove the tube from the heat block, in order to minimize the temperature change of the sample. Gently aliquot $2 \mu \mathrm{L}$ from the very top of the reaction solution. Do not disturb the reaction solution by pipetting.

\subsubsection{Detection of ${ }^{35} \mathrm{~S}-$ Met-Labeled Proteins by SDS-PAGE}

1. After the translation reaction, mix the translation reaction sample $(10 \mu \mathrm{L})$ and $0.4 \mu \mathrm{L}$ of $5 \mathrm{mg} / \mathrm{mL}$ RNase A, and then, incubate for $5 \mathrm{~min}$ at $30^{\circ} \mathrm{C}$. Thereafter, add $2.5 \mu \mathrm{L}$ of $5 x$ LiDS dye to the sample and mix well.

2. Apply the resulting sample onto a $15 \%$ (or $18 \%$ ) SDS-PAGE gel and run it at $190 \mathrm{~V}$ (constant voltage) for approximately $2 \mathrm{~h}$.

3. Immerse the gel in $10 \%$ (vol/vol) acetic acid-10\% (vol/vol) ethanol and shake at room temperature for $30 \mathrm{~min}$.

4. $\quad$ Repeat Step 3.

5. Immerse the gel in $10 \%$ (vol/vol) acetic acid-40\% (vol/vol) ethanol— $3 \%$ (vol/vol) glycerol, and then, shake at room temperature for $1 \mathrm{~h}$.

6. Transfer the gel onto a piece of filter paper, place plastic wrap over the gel, and dry with a gel dryer.

7. Expose the gel on an imaging plate for an appropriate time (approximately $6 \mathrm{~h}$ ) and analyze using a Bio-Analyzing System (BAS5000, Fujifilm). A filter paper spotted with a dilution series of $\left[{ }^{35} \mathrm{~S}\right]$ Met $\left(4.2 \times 10^{-4}-6.8 \times 10^{-2} \mathrm{pmol}\right)$ should be also analyzed, in order to obtain a standard curve for $\left[{ }^{35} \mathrm{~S}\right]$ Met.

\section{Notes}

1. When analyzing peptidyl-tRNAs, the sample is directly mixed with $5 \times$ LiDS dye, without adding RNase A, and subjected to SDS-PAGE analysis.

2. When analyzing short peptides $(<10 \mathrm{kDa})$, Tricine SDS-PAGE analysis is recommended.

\subsubsection{Analysis of Incorporation of ${ }^{35} \mathrm{~S}-$ Met into Oligopeptides}

1. After the translation reaction, mix the translation reaction sample $(10 \mu \mathrm{L})$ and $10 \mu \mathrm{L}$ of $1 \mathrm{M} \mathrm{HCl}$, and then, vortex for $30 \mathrm{~s}$.

2. Add $200 \mu \mathrm{L}$ of ice-cold ethyl acetate to the sample and vortex for $60 \mathrm{~s}$.

NOTE: Tighten the tube lid and do not warm the tube with your fingers. Otherwise, the sample may leak from the tube during vortexing.

3. Keep the sample on ice for $10 \mathrm{~min}$.

4. Centrifuge the sample at maximum speed $(\sim 15,000 \times g)$ for $5 \mathrm{~min}$ at $4{ }^{\circ} \mathrm{C}$. Thereafter, transfer the supernatants $(\sim 160 \mu \mathrm{L})$ to a plastic vial containing $5 \mathrm{~mL}$ of Ultima Gold (Perkin Elmer).

5. Shake the sample vigorously for $10 \mathrm{~min}$ at room temperature.

6. Measure the radioactivity of the sample with a scintillation counter.

\section{Expected Results}

Figure 2 shows the analysis of the translation activity of the prepared ribosomes, where the translation of the polyproline sequence, in response to the $\mathrm{Mg}^{2+}$ concentration and the effect of eIF5A, was examined. Two types of reporter mRNA encoding for nanoluciferase were prepared: no-motif and Prox4. In Prox4 mRNA, the polyproline sequence is inserted in front of the nanoluciferase sequence, while there is no insertion sequence at the corresponding position in no-motif mRNA (Figure 2A, Table S6). These two reporter mRNAs were translated in the presence and absence of eIF5 $\mathrm{A}^{2} \mathrm{Mg}^{2+}$ concentrations of 5, 6, 
and $7 \mathrm{mM}$, and the nanoluciferase activities were measured (Figure 2B). With the ribosomes of this preparation, we consider that the appropriate condition for further studies is $6 \mathrm{mM}$ $\mathrm{Mg}^{2+}$, for the following reasons: (i) polyproline-mediated translation arrest was properly observed (Figure 2B, Panel 5), and (ii) the translation efficiency of the no-motif mRNA in the absence and presence of eIF5A was approximately the same at a reaction time of $120 \mathrm{~min}$ (Figure 2B, Panel 2). Note that, under the $7 \mathrm{mM} \mathrm{Mg}^{2+}$ condition, polyproline-mediated translation arrest was no longer observed (Figure 2B, Panel 6). Moreover, translation of no-motif mRNA was considerably inhibited by eIF5A (Figure 2B, Panel 3). The reason for this is still unclear; one possibility is that eIF5A promotes premature termination at several sites in the ORF (for a detailed discussion, see [24]). On the other hand, under the $5 \mathrm{mM} \mathrm{Mg}^{2+}$ condition, the translation initiation and the early elongation process were presumably inefficient in the absence of eIF5A (Figure 2B, Panel 1). Consequently, the effect of eIF5A on the translation of the polyproline sequence, per se, would not be appropriately evaluated under such a condition (Figure 2B, Panel 4). Figure 2C shows the analysis of the translation products at $6 \mathrm{mM} \mathrm{Mg}^{2+}$ condition by Tricine SDS-PAGE. In agreement with the nanoluciferase activities, the truncated proteins are observed from the Prox 4 mRNAs, and the addition of eIF5A stimulates the production of full-length nanoLuciferase.

For other examples of detailed analyses of translation elongation regulation with the reconstituted yeast translation system, see [24]. Ribosome stalling by the polyproline sequence in either oligopeptides or long polypeptides, CGA codon repeats, and the polytryptophan sequence have been analyzed using the methods described herein. The effect of $\mathrm{Mg}^{2+}$ / polyamine on the translation of the polyproline sequence has also been presented in detail.

Supplementary Materials: The following are available online at https://www.mdpi.com/article/10 $.3390 / \mathrm{mps} 4030045 / \mathrm{s} 1$, Table S1. Summary of the experimentally estimated absorption coefficients of the purified factors, Table S2. Summary of the expression and purification of the components for the reconstituted translation system, Table S3. Yeast strains used for the purification of the components for the reconstituted translation system, Table S4. Translation reaction condition for checking the activity of the components in the reconstituted translation system, Table S5. Components in the reconstituted translation system dissolved in buffer that contained $\mathrm{Mg}^{2+}$, Table S6. Sequence of template DNA.

Author Contributions: Conceptualization and methodology, N.T.-T.; validation and formal analysis, all authors; writing, N.T.-T.; supervision, N.T.-T.; funding acquisition, N.T.-T. All authors have read and agreed to the published version of the manuscript.

Funding: This research was funded by grants from MEXT/JSPS, Grant-in-Aid for Scientific Research (Grant No. 26116002), the Takeda Science Foundation and the Uehara Memorial Foundation to N.T.-T.

Institutional Review Board Statement: Not applicable.

Informed Consent Statement: Not applicable.

Data Availability Statement: Not applicable.

Acknowledgments: The authors sincerely thank Akira Kaji and Hideko Kaji for the TKY675 strain and the plasmid containing the CrPV IGR IRES cDNA, Hiroaki Imataka for human aminoacyl-tRNA synthetases, and Takuya Ueda and all the members of the laboratory for their helpful discussions and continuous support.

Conflicts of Interest: The authors declare no conflict of interest.

\section{Appendix A. Cell lysis}

Disruption of yeast cells by mechanical grinding

1. Fill the grinder (Retsch, Mortar Grinder RM200) with liquid nitrogen and preliminarily run the mortar before adding frozen cells. 
A CRITICAL STEP Pre-cool the mortar and pestle with liquid nitrogen before cell lysis, in order to prevent frozen cells from melting. We recommend pre-running the grinder fully filled with liquid nitrogen more than three times, until boiling of the liquid nitrogen stops.

2. Pour liquid nitrogen and transfer $15 \mathrm{~g}$ of frozen cells ( $30 \mathrm{~g}$ of yeast drops) into the mortar, and grind them for 2-3 min.

3. Repeat step 2 about five times ( $15 \mathrm{~min}$ in total).

4. Transfer the frozen powder to tubes with a pre-chilled spatula.

Disruption of $E$. coli cells by sonication

1. Resuspend cells with $5 \mathrm{~mL}$ of ice-cold lysis buffer per $1 \mathrm{~g}$ of cells.

2. The mixture is transferred to an $100 \mathrm{~mL}$ aluminum container and placed on ice.

A CRITICAL STEP The volume of the sample should not exceed $75 \mathrm{~mL}$ for efficient disruption.

3. Disrupt the cells using a sonicator (Branson, Digital Sonifier 450) (Run time: 5 min, Pulse on: 2 s, Pulse off: 8 s, Power: 80 watt), until the lysate becomes clear.

\section{Appendix B. Preparation of mRNA}

\section{Preparation of template DNA by PCR}

Prepare the PCR mixture $(200 \mu \mathrm{L})$ in $0.2 \mathrm{~mL}$ tubes, as follows: Mix $12 \mu \mathrm{L}$ of $25 \mathrm{mM} \mathrm{MgSO}_{4}$, $20 \mu \mathrm{L}$ of $10 \times$ PCR Buffer for KOD-Plus-Neo, $20 \mu \mathrm{L}$ of $2 \mathrm{mM}$ dNTPs, $6 \mu \mathrm{L}$ of $10 \mu \mathrm{M}$ forward primer, $6 \mu \mathrm{L}$ of $10 \mu \mathrm{M}$ reverse primer, $100 \mathrm{ng}$ of chemically synthesized DNA fragments (Table S5) or plasmid harboring the desired sequence, $4 \mu \mathrm{L}$ of KOD-Plus-Neo (Toyobo), and RNase-free water to $200 \mu \mathrm{L}$. Run the sample in a thermal cycler with the following program: $94^{\circ} \mathrm{C}$ for $2 \mathrm{~min}$, and 30 cycles of $98^{\circ} \mathrm{C}$ for $10 \mathrm{~s}, 57^{\circ} \mathrm{C}$ for $15 \mathrm{~s}$, and $68^{\circ} \mathrm{C}$ for $30 \mathrm{~s}$ per $1 \mathrm{~kb}$ amplified sequence. After PCR, add $4 \mu \mathrm{L}$ of $D p n$ I to the sample $(200 \mu \mathrm{L})$ and incubate at $37^{\circ} \mathrm{C}$ for $1 \mathrm{~h}$. Purify the sample using Wizard SV Gel and PCR Clean-Up System (Promega), according to the manufacturer's instructions. Measure the concentration of the PCR product using a spectrometer and check the amplified DNA templates using agarose gel electrophoresis. The DNA templates are aliquoted to minimize freeze-thawing, and stored at $-30^{\circ} \mathrm{C}$.

\section{Analysis of template DNA by agarose gel electrophoresis}

Mix 0.1 volumes of $10 \times$ Loading Buffer (Takara) and $1000 \mathrm{ng}$ of the template DNAs by PCR. Apply the resulting sample onto $1 \%$ agarose gel and run it with $0.5 \times$ TAE at $100 \mathrm{~V}$ for 30-40 min. Stain the gel with 1/20,000-diluted EtBr solution with gentle shaking for $30 \mathrm{~min}$. Scan the gel image with a gel scanner.

\section{In vitro transcription of $\mathrm{mRNAs}$}

Prepare the reaction mixture $(100 \mu \mathrm{L})$ in a microtube, as follows: Mix $10 \mu \mathrm{L}$ of $10 \times \mathrm{T} 7$ buffer, $3.75 \mu \mathrm{L}$ of $100 \mathrm{mM}$ ATP, $3.75 \mu \mathrm{L}$ of $100 \mathrm{mM}$ GTP, $3.75 \mu \mathrm{L}$ of $100 \mathrm{mM} \mathrm{CTP}, 3.75 \mu \mathrm{L}$ of $100 \mathrm{mM}$ UTP, $5 \mu \mathrm{L}$ of $100 \mathrm{mM}$ DTT, $10 \mu \mathrm{L}$ of $0.1 \%$ (wt/vol) BSA (TAKARA), $2.5 \mu \mathrm{L}$ of Recombinant RNase Inhibitor (Takara), $1650 \mathrm{ng}$ of template DNA, pyrophosphatase $(100 \mu \mathrm{g} / \mathrm{mL}$ final), T7 RNA polymerase $(120 \mu \mathrm{g} / \mathrm{mL}$ final), and RNase-free water to $100 \mu \mathrm{L}$. Incubate the reaction mixture at $37^{\circ} \mathrm{C}$ for $4 \mathrm{~h}$. Add $1 \mu \mathrm{L}$ of TURBO DNase (Thermo Fisher Scientific) to the sample $(100 \mu \mathrm{L})$ and incubate at $37^{\circ} \mathrm{C}$ for $15 \mathrm{~min}$. After the reaction, add $35 \mu \mathrm{L}$ of RNase-free water and $14 \mu \mathrm{L}$ (1/10 volumes) of $5 \mathrm{M}$ ammonium acetate- $100 \mathrm{mM}$ EDTA into the mixture, in order to quench the reaction. Add $150 \mu \mathrm{L}$ (1 volume) of phenol saturated with $\mathrm{H}_{2} \mathrm{O}$ into the mixture and vortex well. Centrifuge the mixture at 20,000 $\mathrm{g}$ for $5 \mathrm{~min}$ at $27^{\circ} \mathrm{C}$. Thereafter, transfer the supernatant to a clean tube. Add $150 \mu \mathrm{L}$ ( 1 volume) of chloroform into the sample and vortex well. Centrifuge the mixture at 20,000 $\mathrm{g}$ for $5 \mathrm{~min}$ at $27^{\circ} \mathrm{C}$. Thereafter, transfer the supernatant to a clean tube. Add $300 \mu \mathrm{L}$ (2 volumes) of ice-cold $100 \%$ (vol/vol) ethanol into the sample and vortex well. Centrifuge the mixture at $20,000 \mathrm{~g}$ for $15 \mathrm{~min}$ at $4{ }^{\circ} \mathrm{C}$. Thereafter, aspirate off the supernatant. Gently add $500 \mu \mathrm{L}$ of ice-cold 70\% (vol/vol) ethanol to the pellet, to rinse. Centrifuge the sample at 20,000 $\mathrm{g}$ for 5 min at $4{ }^{\circ} \mathrm{C}$. Thereafter, aspirate off the supernatant. Dry the pellet for 5 min at $27^{\circ} \mathrm{C}$. Add 
$37.5 \mu \mathrm{L}$ of RNase-free water and dissolve the pellet. The sample is further purified using Micro Bio-Spin columns P30 (Bio-Rad) to remove NTPs, according to the manufacturer's instructions. Measure the concentration of the mRNA using a spectrometer and check the mRNA using denaturing agarose gel electrophoresis. The mRNAs are aliquoted, to minimize freeze-thawing, and stored at $-80^{\circ} \mathrm{C}$.

\section{Analysis of $m R N A s$ by denaturing agarose gel electrophoresis}

Mix $500 \mathrm{ng}$ of mRNA, $0.5 \mu \mathrm{L}$ of $20 \times$ MOPS running buffer ( $\mathrm{pH} 7.0$ ), $3.5 \mu \mathrm{L}$ of formaldehyde, $10 \mu \mathrm{L}$ of formamide, $1 \mu \mathrm{L}$ of $1 \mathrm{mg} / \mathrm{mL} \mathrm{EtBr}$, and RNase-free water to $20 \mu \mathrm{L}$. Incubate the mixture for $10 \mathrm{~min}$ at $65^{\circ} \mathrm{C}$. Add $2 \mu \mathrm{L}$ of $10 \times$ RNA loading dye to the sample $(20 \mu \mathrm{L})$. Apply the resulting sample onto a $1 \%$ agarose/formaldehyde gel and run it with $1 \times$ MOPS running buffer at $100 \mathrm{~V}$ for $30 \mathrm{~min}$. Scan the gel image with a gel scanner.

\section{Reagents set-up}

50× TAE: Mix $242 \mathrm{~g}$ of Tris, $57.1 \mathrm{~mL}$ of acetic acid, and $100 \mathrm{~mL}$ of 0.5 M EDTA (pH 8.0), then add RNase-free water up to $1 \mathrm{~L}$. Then, autoclave it. Can be stored at room temperature. $0.5 \times$ TAE: Mix $990 \mathrm{~mL}$ of RNase-free water and $10 \mathrm{~mL}$ of $50 \times$ TAE. Can be stored at room temperature.

1\% Agarose gel: Mix $200 \mathrm{~mL}$ of $0.5 \times \mathrm{TAE}$ and $2 \mathrm{~g}$ of agarose (1\% (wt/vol) final), and then, microwave it until the agarose dissolves completely. Cool the solution to about $60{ }^{\circ} \mathrm{C}$ and pour into a gel tray with the well comb in place.

$10 \times$ T7 buffer: $400 \mathrm{mM}$ Tris- $\mathrm{HCl}(\mathrm{pH} 8.0), 220 \mathrm{mM} \mathrm{MgCl}_{2}$, and $10 \mathrm{mM}$ spermidine. Mix $20 \mathrm{~mL}$ of $1 \mathrm{M}$ Tris- $\mathrm{HCl}(\mathrm{pH} 8.0), 11 \mathrm{~mL}$ of $1 \mathrm{M} \mathrm{MgCl}_{2}$, and $500 \mu \mathrm{L}$ of $1 \mathrm{M}$ spermidine, then add RNase-free water up to $50 \mathrm{~mL}$. Can be stored at $-30^{\circ} \mathrm{C}$.

$5 \mathrm{M}$ ammonium acetate-100 mM EDTA: Mix $9.64 \mathrm{~g}$ of ammonium acetate and $5 \mathrm{~mL}$ of $0.5 \mathrm{M}$ EDTA (pH 8.0), then add RNase-free water up to $25 \mathrm{~mL}$.

$20 \times$ MOPS running buffer (pH 7.0): $400 \mathrm{mM}$ MOPS-NaOH (pH 7.0), $100 \mathrm{mM} \mathrm{NaOAc}$, and $20 \mathrm{mM}$ EDTA. Mix $41.9 \mathrm{~g}$ of MOPS, $4.10 \mathrm{~g}$ of NaOAc (anhydrous), and $3.72 \mathrm{~g}$ of EDTA.2Na, then add RNase-free water up to $400 \mathrm{~mL}$. Add $1 \mathrm{M} \mathrm{NaOH}$ (approximately $90 \mathrm{~mL}$ ) into the solution until the $\mathrm{pH}$ reaches 7.0. After $\mathrm{pH}$ adjustment, add RNase-free water up to $500 \mathrm{~mL}$. Then, autoclave it. Can be stored away from light at room temperature. 1× MOPS running buffer (pH 7.0): Mix $380 \mathrm{~mL}$ of RNase-free water and $20 \mathrm{~mL}$ of $20 \times$ MOPS running buffer ( $\mathrm{pH}$ 7.0). Prepare fresh before use.

1\% Agarose/formaldehyde gel: Mix $67.2 \mathrm{~mL}$ of RNase-free water, $3.75 \mathrm{~mL}$ of $20 \times$ MOPS running buffer ( $\mathrm{pH} 7.0)$, and $0.75 \mathrm{~g}$ of agarose $(1 \%(\mathrm{wt} / \mathrm{vol})$ final), then microwave it until the agarose dissolves completely. After the solution has cooled down to about $60{ }^{\circ} \mathrm{C}$, add $4.12 \mathrm{~mL}$ of formaldehyde using a magnetic stirrer. This operation should be performed in a draft, in order to avoid inhalation of formaldehyde. Set a gel tray with the well comb in place in the draft, and pour the solution into the tray.

$10 \times$ RNA loading dye: $0.25 \%$ (wt/vol) bromophenol blue (BPB), $0.25 \%(\mathrm{wt} / \mathrm{vol})$ Xylene cyanole FF (XC), $2.5 \mathrm{mM}$ EDTA, and $7 \mathrm{M}$ urea. Mix $25 \mathrm{mg}$ of BPB, $25 \mathrm{mg}$ of $\mathrm{XC}, 50 \mu \mathrm{L}$ of $0.5 \mathrm{M}$ EDTA ( $\mathrm{pH} 8.0$ ), and $4.2 \mathrm{~g}$ of urea, then add RNase-free water up to $10 \mathrm{~mL}$. Can be stored at $-30^{\circ} \mathrm{C}$.

\section{Appendix C. Preparation of eIF5A}

The hypusinated eIF5A protein, eIF5A(hyp), is prepared according to [24]. The eIF5A_DHS_ $\mathrm{DOHH} / \mathrm{pET} 29 \mathrm{~b}$ plasmid is used for the co-expression of non-tagged eIF5A with Dys1 and Lia1 in E. coli. The plasmid is transformed into E. coli Rosetta(DE3)pLysS. The cells are grown at $37^{\circ} \mathrm{C}$ to an $\mathrm{OD}_{600}$ of 0.5 , and protein expression is induced with $1 \mathrm{mM}$ IPTG at $18^{\circ} \mathrm{C}$ overnight. The cells are resuspended in a five-fold volume of Buffer A (50 mM Tris-KOAc [pH 7.0], $100 \mathrm{mM} \mathrm{KCl}, 0.1 \mathrm{mM}$ EDTA, $1 \mathrm{mM} \mathrm{DTT}$ ) and lysed by sonication. After centrifugation at $25,000 \times \mathrm{g}$ for $15 \mathrm{~min}$, the supernatant is collected. The proteins are subjected to HiPrep $Q$ anion exchange chromatography (GE Healthcare), in $50 \mathrm{mM}$ Tris-KOAc [pH 7.0], 100-500 mM KCl, 0.1 mM EDTA, and 1 mM DTT. Typically, eIF5A is eluted at about $450 \mathrm{mM} \mathrm{KCl}$. The eluted fraction is dialyzed against Buffer A. The protein is further purified by HiTrap SP HP chromatography (GE Healthcare), in $50 \mathrm{mM}$ 
Tris-KOAc [pH 7.0], 100-500 mM KCl, $0.1 \mathrm{mM}$ EDTA, and $1 \mathrm{mM}$ DTT. eIF5A is usually eluted at about $440 \mathrm{mM} \mathrm{KCl}$. The eluted fraction is dialyzed against stock buffer $(20 \mathrm{mM}$ Hepes-KOH [pH 7.6], $100 \mathrm{mM} \mathrm{KCl,10 \%} \mathrm{glycerol,} 7 \mathrm{mM}$ 2-mercaptoethanol), concentrated to $5 \mathrm{mg} / \mathrm{mL}$, and frozen in small aliquots at $-80^{\circ} \mathrm{C}$. Yield of eIF5A(hyp) from $1 \mathrm{~L}$ culture is approximately $14.3 \mathrm{mg}$. Full hypusine modification of the obtained eIF5A has been confirmed by mass spectrometric analysis.

\section{References}

1. Shimizu, Y.; Inoue, A.; Tomari, Y.; Suzuki, T.; Yokogawa, T.; Nishikawa, K.; Ueda, T. Cell-free translation reconstituted with purified components. Nat. Biotechnol. 2001, 19, 751-755. [CrossRef]

2. Zhou, Y.; Asahara, H.; Gaucher, E.A.; Chong, S. Reconstitution of translation from Thermus thermophilus reveals a minimal set of components sufficient for protein synthesis at high temperatures and functional conservation of modern and ancient translation components. Nucleic Acids Res. 2012, 40, 7932-7945. [CrossRef] [PubMed]

3. Srivastava, A.; Asahara, H.; Zhang, M.; Zhang, W.; Liu, H.; Cui, S.; Jin, Q.; Chong, S. Reconstitution of protein translation of mycobacterium reveals functional conservation and divergence with the Gram-negative bacterium Escherichia coli. PLoS ONE 2016, 11, e0162020. [CrossRef]

4. Machida, K.; Mikami, S.; Masutani, M.; Mishima, K.; Kobayashi, T.; Imataka, H. A Translation System Reconstituted with Human Factors Proves That Processing of Encephalomyocarditis Virus Proteins 2A and 2B Occurs in the Elongation Phase of Translation without Eukaryotic Release Factors. J. Biol. Chem. 2014, 289, 31960-31971. [CrossRef] [PubMed]

5. Lee, M.; Matsunaga, N.; Akabane, S.; Yasuda, I.; Ueda, T.; Takeuchi-Tomita, N. Reconstitution of mammalian mitochondrial translation system capable of correct initiation and long polypeptide synthesis from leaderless mRNA. Nucleic Acids Res. 2021, 49, 371-382. [CrossRef]

6. Hinnebusch, A.G.; Lorsch, J.R. The mechanism of eukaryotic translation initiation: New insights and challenges. Cold Spring Harb. Perspect. Biol. 2012, 4, a011544. [CrossRef]

7. Acker, M.G.; Kolitz, S.E.; Mitchell, S.F.; Nanda, J.S.; Lorsch, J.R. Reconstitution of yeast translation initiation. Meth. Enzymol. 2007, 430, 111-145.

8. Saini, P.; Eyler, D.E.; Green, R.; Dever, T.E. Hypusine-containing protein eIF5A promotes translation elongation. Nature 2009, 459, 118-121. [CrossRef]

9. Schuller, A.P.; Wu, C.C.; Dever, T.E.; Buskirk, A.R.; Green, R. eIF5A functions globally in translation elongation and termination. Mol. Cell 2017, 66, 194-205. [CrossRef]

10. Tesina, P.; Lessen, L.N.; Buschauer, R.; Cheng, J.; Wu, C.C.; Berninghausen, O.; Buskirk, A.R.; Becker, T.; Beckmann, R.; Green, R. Molecular mechanism of translational stalling by inhibitory codon combinations and poly(A) tracts. EMBO J. 2019,39 , e103365. [CrossRef] [PubMed]

11. Dever, T.E.; Green, R. The elongation, termination, and recycling phases of translation in eukaryotes. Cold Spring Harb. Perspect. Biol. 2012, 4, a013706. [CrossRef]

12. Eyler, D.E.; Green, R. Distinct response of yeast ribosomes to a miscoding event during translation. RNA 2011, 17, 925-932. [CrossRef]

13. Shoemaker, C.J.; Eyler, D.E.; Green, R. Dom34: Hbs1 promotes subunit dissociation and peptidyl-tRNA drop-off to initiate no-go decay. Science 2010, 330, 369-372. [CrossRef] [PubMed]

14. Shoemaker, C.J.; Green, R. Kinetic analysis reveals the ordered coupling of translation termination and ribosome recycling in yeast. Proc. Natl. Acad. Sci. USA 2011, 108, E1392-E1398. [CrossRef] [PubMed]

15. Ranjan, N.; Pochopien, A.A.; Wu, C.C.C.; Beckert, B.; Blanchet, S.; Green, R.; Rodnina, M.V.; Wilson, D.N. Yeast translation elongation factor eEF3 promotes late stages of tRNA translocation. EMBO J. 2021, 40, e106449. [CrossRef] [PubMed]

16. Ibba, M.; Soll, D. Aminoacyl-tRNA synthesis. Annu. Rev. Biochem. 2000, 69, 617-650. [CrossRef]

17. Koehler, C.; Round, A.; Simader, H.; Suck, D.; Svergun, D. Quaternary structure of the yeast Arc1p-aminoacyl-tRNA synthetase complex in solution and its compaction upon binding of tRNAs. Nucleic Acids Res. 2013, 41, 667-676. [CrossRef] [PubMed]

18. Abe, T.; Nagai, R.; Imataka, H.; Takeuchi-Tomita, N. Reconstitution of yeast translation elongation and termination in vitro utilizing CrPV IRES-containing mRNA. J. Biochem. 2020. [CrossRef]

19. Fernandez, I.S.; Bai, X.C.; Murshudov, G.; Scheres, S.H.; Ramakrishnan, V. Initiation of translation by cricket paralysis virus IRES requires its translocation in the ribosome. Cell 2014, 157, 823-831. [CrossRef] [PubMed]

20. Hodgman, C.E.; Jewett, M.C. Characterizing IGR IRES-mediated translation initiation for use in yeast cell-free protein synthesis. New Biotechnol. 2014, 31, 499-505. [CrossRef]

21. Andersen, C.B.F.; Becker, T.; Blau, M.; Anand, M.; Halic, M.; Balar, B.; Mielke, T.; Boesen, T.; Pedersen, J.S.; Spahn, C.M.T.; et al. Structure of eEF3 and the mechanism of transfer RNA release from the E-site. Nature 2006, 443, 663-668. [CrossRef]

22. Triana-Alonso, F.J.; Chakraburtty, K.; Nierhaus, K.H. The elongation factor 3 unique in higher fungi and essential for protein biosynthesis is an E site factor. J. Biol. Chem. 1995, 270, 20473-20478. [CrossRef]

23. Skogerson, L.; Engelhardt, D. Dissimilarity in protein chain elongation factor requirements between yeast and rat liver ribosomes. J. Biol. Chem. 1977, 252, 1471-1475. [CrossRef] 
24. Abe, T.; Nagai, R.; Shimazaki, S.; Kondo, S.; Nishimura, S.; Sakaguchi, Y.; Suzuki, T.; Imataka, H.; Tomita, K.; Takeuchi-Tomita, $\mathrm{N}$. In vitro yeast reconstituted translation system reveals function of eIF5A for synthesis of long polypeptide. J. Biochem. 2020. [CrossRef] [PubMed]

25. Petrov, A.; Grosely, R.; Chen, J.; O'Leary, S.E.; Puglisi, J.D. Multiple parallel pathways of translation initiation on the CrPV IRES. Mol. Cell 2016, 62, 92-103. [CrossRef] [PubMed]

26. Chadani, Y.; Niwa, T.; Izumi, T.; Sugata, N.; Nagao, A.; Suzuki, T.; Chiba, S.; Ito, K.; Taguchi, H. Intrinsic ribosome destabilization underlies translation and provides an organism with a strategy of environmental sensing. Mol. Cell 2017, 68, 528-539. [CrossRef] [PubMed]

27. Hetrick, B.; Khade, P.K.; Lee, K.; Stephen, J.; Thomas, A.; Joseph, S. Polyamines accelerate codon recognition by transfer RNAs on the ribosome. Biochemistry 2010, 49, 7179-7189. [CrossRef] [PubMed] 